UNIVERSIDADE DE SÃO PAULO

BRUNO JOSÉ BETTI GALASSO

Perspectivas para as Línguas Portuguesa e Espanhola diante da integração de anglicismos: uma análise por meio de periódicos

São Paulo 


\section{Perspectivas para as Línguas Portuguesa e Espanhola diante da integração de anglicismos: uma análise por meio de periódicos}

Dissertação apresentada ao programa de PósGraduação em Integração da América Latina da Universidade de São Paulo -PROLAM/USPpara obtenção do título de Mestre em Integração da América Latina Área de Concentração: Comunicação e Cultura Orientador: Prof. Dr. Luiz Antônio Lindo

São Paulo 2009 


\section{FOLHA DE APROVAÇÃO}

Bruno José Betti Galasso

Perspectivas para as Línguas Portuguesa e Espanhola diante da integração de anglicismos: uma análise por meio de periódicos

Dissertação apresentada ao programa de PósGraduação em Integração da América Latina da Universidade de São Paulo -PROLAM/USPpara obtenção do título de Mestre em Integração da América Latina Área de Concentração: Comunicação e Cultura Orientador: Prof. Dr. Luiz Antônio Lindo

Aprovado em:

Banca Examinadora

Prof. Dr.

Instituição: Assinatura:

Prof. Dr. Instituição: Assinatura:

Prof. Dr. Instituição: Assinatura:

Prof. Dr. Instituição: Assinatura:

Prof. Dr. Instituição: Assinatura: 


\section{DEDICATÓRIA}

Aos meus pais,

José Francisco Ribeiro Galasso e Odete Aparecida Betti Ribeiro Galasso, com todo o meu amor. 


\section{AGRADECIMENTOS}

Ao Prof. Dr. Luiz Antônio Lindo, meu orientador, pela atenção e apoio durante todo o processo deste trabalho.

Ao Dr. Nelson Bedin, que, além de revisar o trabalho, muito me ensinou, contribuindo para o meu crescimento científico e intelectual.

Ao Prof. Artur Araújo, pelas elucidações e auxílio no começo desse processo.

À minha mãe, rainha do meu reino de sonhos, mulher íntegra e forte, por me ensinar que a vida é um milagre.

Ao meu pai, o homem mais forte que conheço e admiro, por me ilustrar diariamente em nossas conversas e me ensinar que a experiência não é o que acontece a um homem, mas sim o que um homem faz com o que the acontece.

Aos meus irmãos, Alessandra e José Francisco, por dividirem comigo todos os momentos, me ensinando que a relação entre irmãos é a mais complexa e duradoura entre os seres humanos.

Aos meus sobrinhos, Vital e Clara, que dividem comigo a plenitude da vida, me mostrando que cada dia juntos é uma vida inteira.

À Marli, minha segunda mãe, responsável pela organização e conforto do meu dia a dia.

À Maria Laura, mulher com quem eu me casaria todos os dias, por me apoiar diariamente e me ajudar na formatação da dissertação.

E, por fim, a todos os amigos e pessoas que me ajudaram em todos os momentos, pois nenhum trabalho é realizado sozinho. 
"O essencial para a nossa felicidade é a condição íntima, e desta, somos nós os senhores." 


\section{RESUMO}

Galasso, B.J.B. Perspectivas para as Línguas Portuguesa e Espanhola diante da integração de anglicismos: uma análise por meio de periódicos. 2009. 174f. Dissertação (Mestrado) - Programa de Pós-Graduação em Integração da América Latina, Universidade de São Paulo, São Paulo, 2009.

O presente trabalho tem por objetivo identificar e avaliar a integração de anglicismos apresentados nas línguas ibero-americanas por meio de jornais impressos e suas respectivas versões on-line. Na primeira parte da dissertação, desenvolvemos considerações de ordem teórica, identificando influências da presença excessiva e contínua dos anglicismos nas sociedades latino-americanas. Para a construção da pesquisa, analisamos edições impressas e on-line dos seguintes jornais: Folha de $\mathrm{S}$. Paulo (Brasil), El Mercurio (Chile) e Clarín (Argentina). Foram pesquisadas palavras do idioma inglês nos textos dos jornais selecionados, sem considerar os nomes próprios, de pessoas, lugares, títulos de livros, filmes, músicas e espetáculos. Considerando a absorção lexical um processo natural de linguagem, esta dissertação busca ampliar a compreensão acerca de como se processa a trajetória lexical operada entre a língua inglesa norte-americana e as línguas faladas na América do Sul. Dessa forma, constatamos que a incorporação do anglicismo ao vernáculo se dá, em sua maioria, por falta de uma palavra equivalente na língua recebedora e, outras vezes, por motivos diversos, como modismo, status ou corporativismo. Entretanto, essa troca contribui para esses sistemas lingüísticos, pois a língua é uma forma de comunicação mutável, que acompanha e expressa às tendências dos povos.

Palavras-chave: Anglicismos, empréstimos léxicos, estrangeirismos, transferência lingüística. 


\begin{abstract}
Galasso, B.J.B. Perspectives to Portuguese and Spanish languages faced with the integration of anglicisms: an analysis through newspapers. 2009. 174p. Dissertation (Master's Degree) - Programa de Pós-Graduação em Integração da América Latina, Universidade de São Paulo, São Paulo, 2009.

The present work is designed to identify and assess the integration of Anglicisms occurring in Ibero-American languages by means of print newspapers and their respective online versions. In the first part of the dissertation, we expound theoretical considerations, identifying influences of the excessive, ongoing presence of Anglicisms in Latin-American societies. So as to prepare the research, we examined print and online editions of the following newspapers: Folha de S. Paulo (Brazil), El Mercurio (Chile) and Clarín (Argentina). Words from the English language were researched in the texts of the selected newspapers, excluding proper nouns, names of persons or places, titles of books, films, music and entertainments. Considering lexical absorption as a natural process in language, this dissertation aims to deepen the understanding on how the lexical trajectory between the North-American English language and the languages spoken in South America is processed. As a result, we established that Anglicism incorporation to the vernacular occurs, in most cases, when the borrowing language lacks an equivalent word, and sometimes for other reasons, such as fad, status expression or professional jargon. However, this replacement contributes to these linguistic systems, since language is a changing communication tool, always following and expressing the trends of peoples.
\end{abstract}

Key words: Anglicisms, lexical borrowings, foreignisms, linguistic transfer. 


\section{RESUMEN}

Galasso, B.J.B. Perspectivas para las lenguas Portuguesa y Española frente la integración de anglicismos: un análisis por medio de periódicos. 2009. 174h. Disertación (Masters) - Programa de Pós-Graduación en Integración de América Latina, Universidade de São Paulo, São Paulo, 2009.

El presente trabajo tiene como objetivo identificar y evaluar la integración de anglicismos presentes en las lenguas iberoamericanas a través de diarios impresos y sus respectivas versiones on-line. En la primer parte de la disertación, desenvolvemos consideraciones de orden teórica, identificando influencias de la presencia excesiva y contínua de los anglicismos en las sociedades latinoamericanas. Para la construcción de la investigación, analizamos los siguientes diarios: Folha de S. Paulo (Brasil), El Mercurio (Chile) y Clarín (Argentina).

Se investigaron palabras del idioma inglés en los textos de los diarios seleccionados, sin considerar los nombres propios de personas, lugares, títulos de libros, películas, canciones y espectáculos. Considerando la absorción lexical un proceso natural del lenguaje, esta disetación busca ampliar la comprensión acerca de cómo se procesa la trayectoria lexical operada entre la lengua inglesa norteamericana y las lenguas habladas en América del Sur. De esa forma, constatamos que la incorporación del anglicismo al vernáculo se dá, en su mayoría, por la falta de una palabra equivalente en la lengua recibidora y, otras veces, por motivos diversos, como modismos, status o corporativismos. Entretanto, este trueque contribuye para esos sistemas lingüísticos, pues la lengua es una forma de comunicación mutable, que acompaña y expresa las tendencias de los pueblos.

Palabras clave: Anglicismos, préstamos léxicos, extranjerismos, transferencia lingüística. 


\section{SUMÁRIO}

INTRODUÇÃO

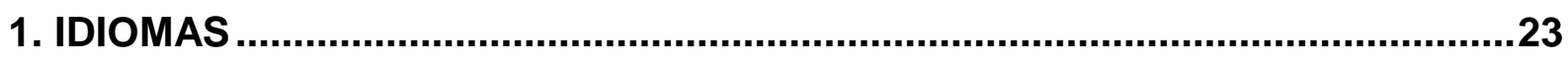

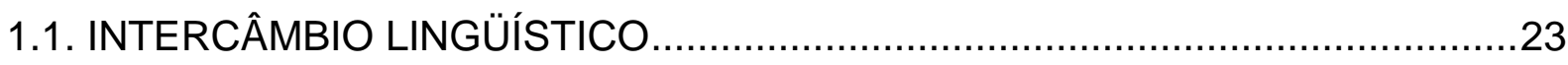

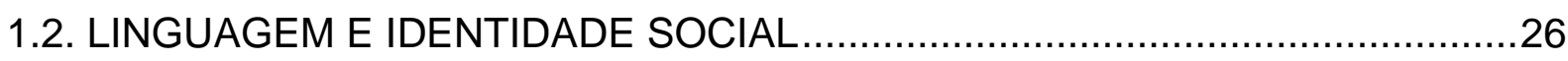

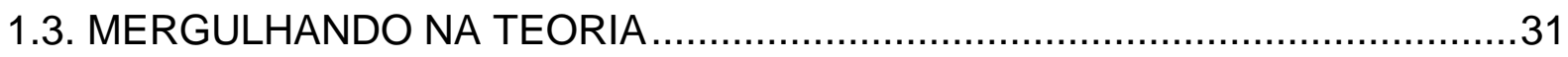

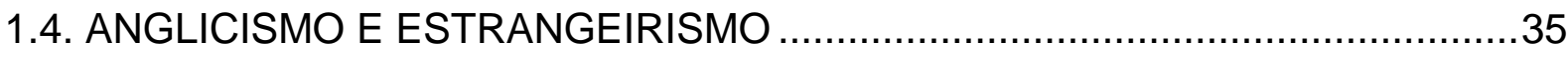

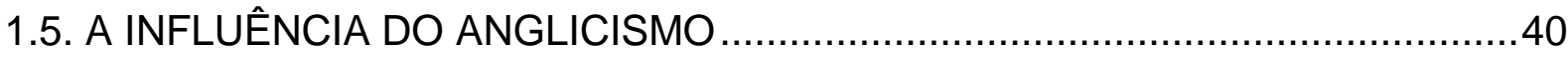

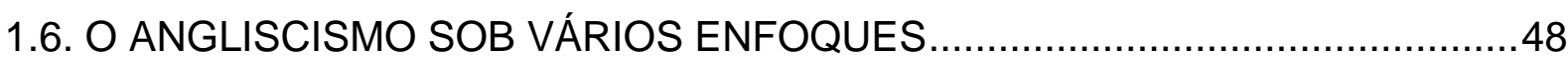

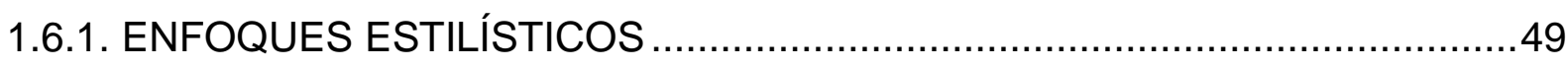

1.6.2. ENFOQUES FUNCIONALISTAS NO MARCO DA LINGÜÍSTICA

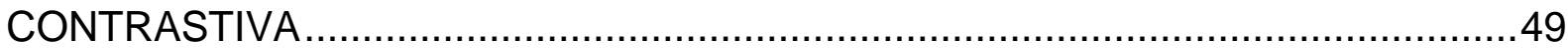

1.6.3. O ENFOQUE TRADUTOLÓGICO: FALTA DE EQUIVALÊNCIAS PERFEITAS E EXCESSIVA FREQÜÊNCIA DE MODELOS ESTRANGEIROS ….......................50

1.6.4. O ENFOQUE PROPRIAMENTE PRAGMÁTICO: A COMPETÊNCIA

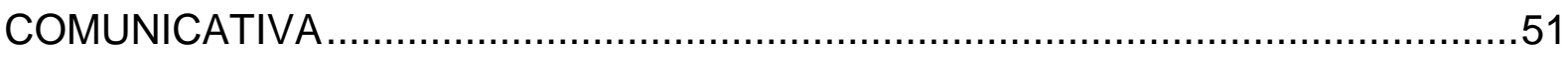

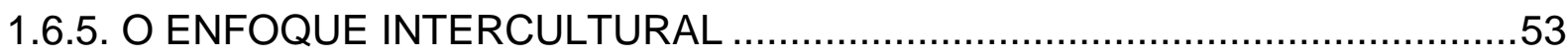

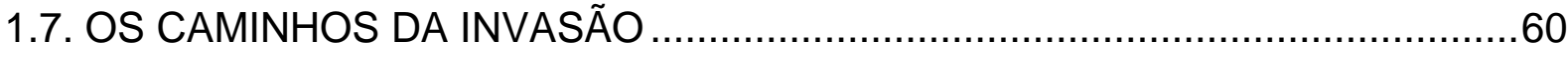

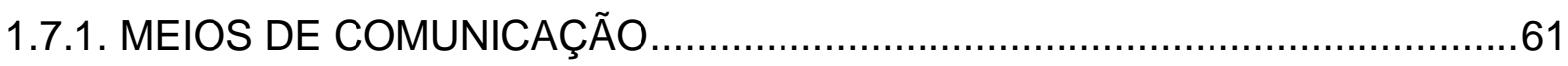

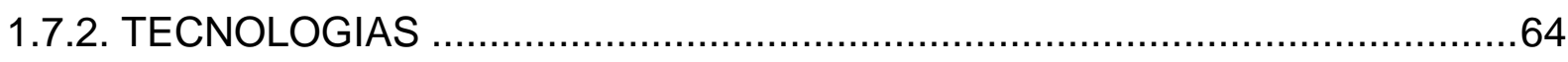

1.7.3. O FATOR ECONÔMICO, INDUSTRIAL E COMERCIAL DOS ESTADOS

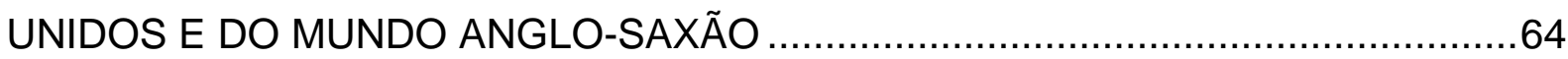

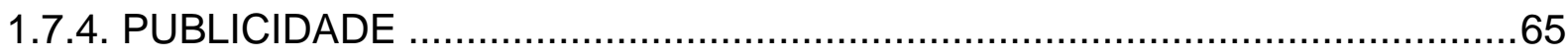

1.7.5. POLÍTICAS INTERNACIONAIS E GLOBALIZAÇÃO .....................................66 


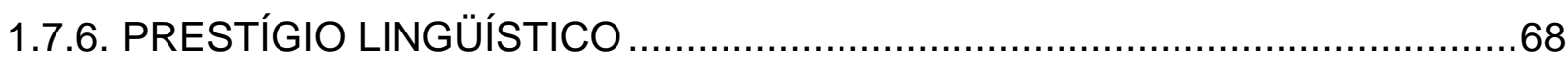

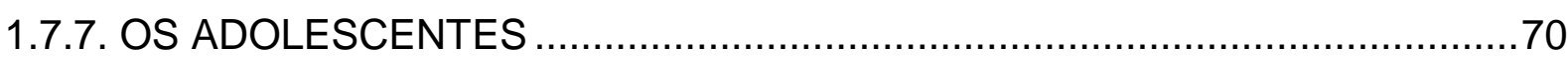

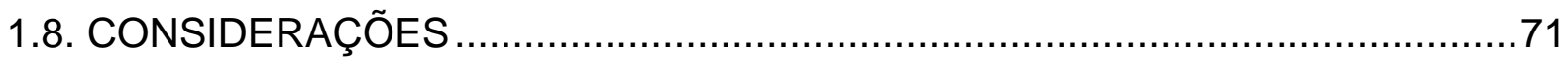

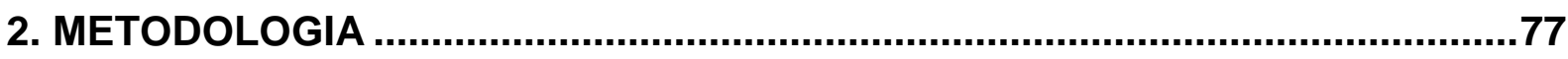

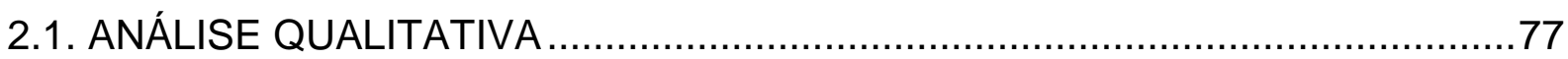

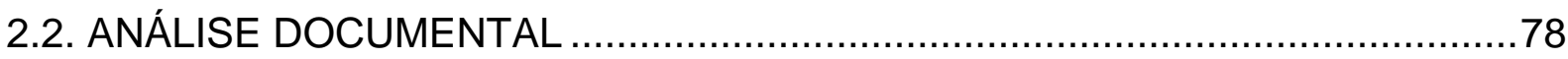

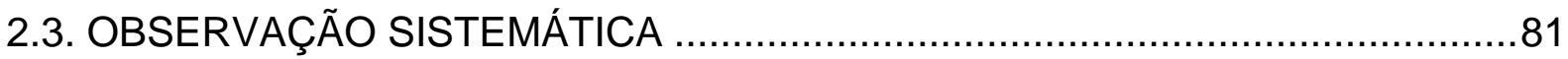

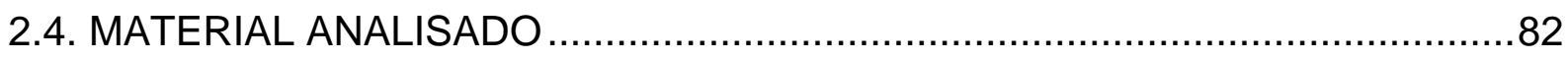

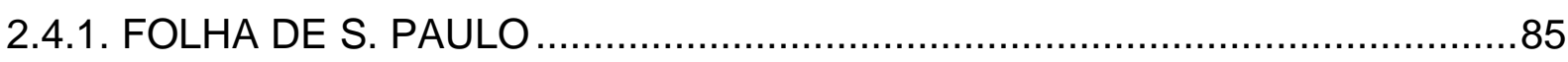

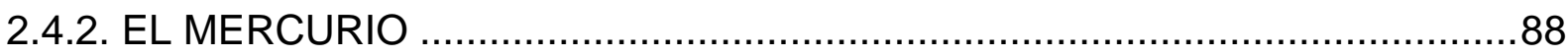

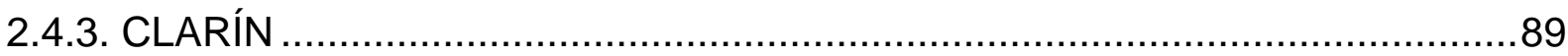

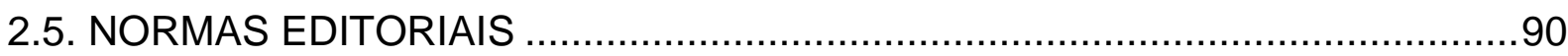

3. ANALISANDO OS ESTRANGEIRISMOS …..................................................95

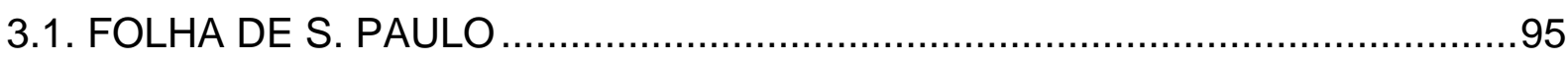

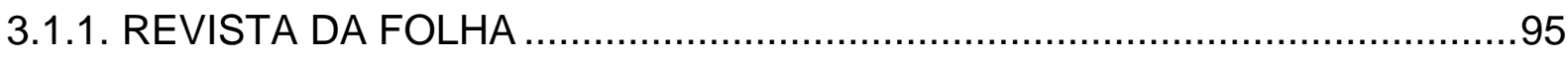

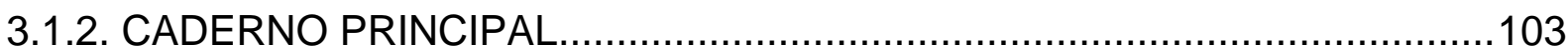

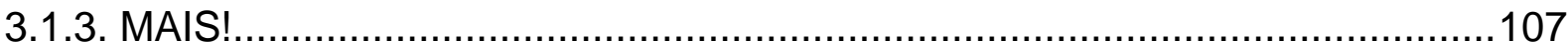

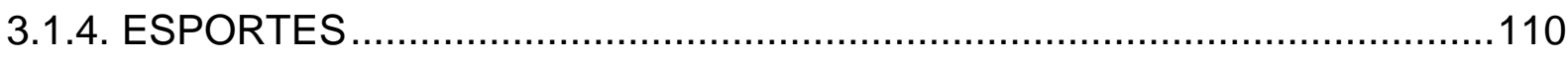

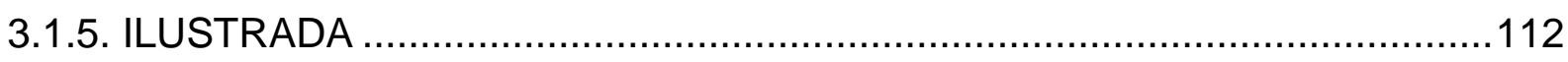

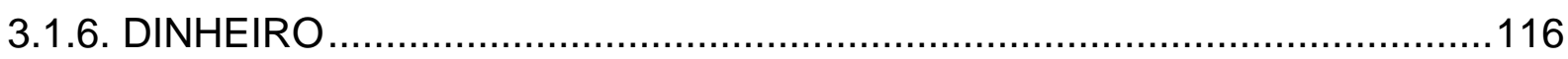

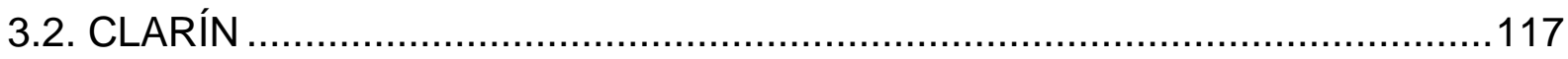

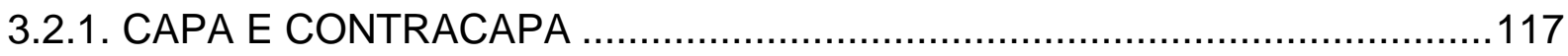

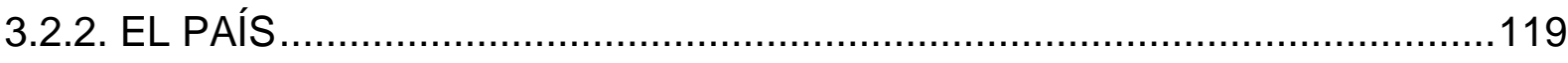

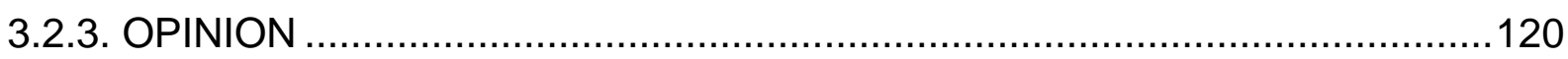

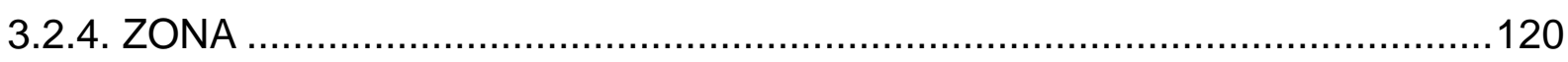


3.2.5. SOCIEDAD

3.2.6. VIAJES 122

3.2.7. IECO 122

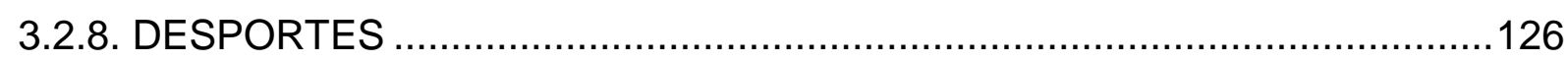

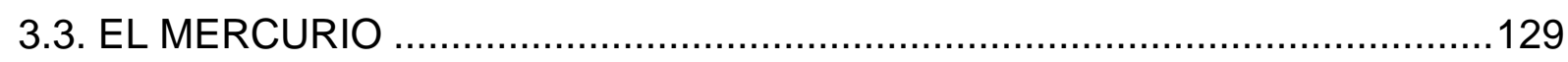

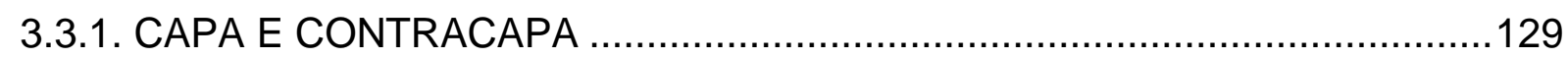

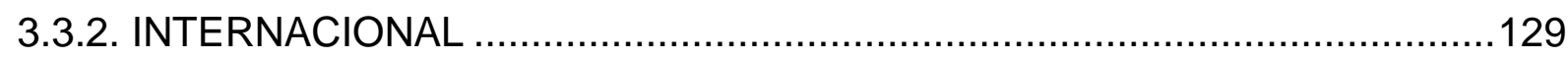

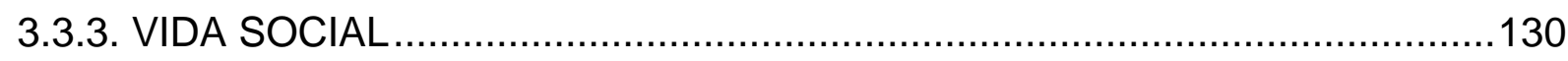

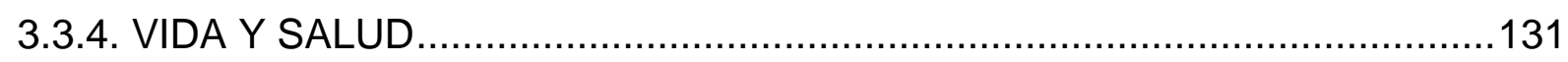

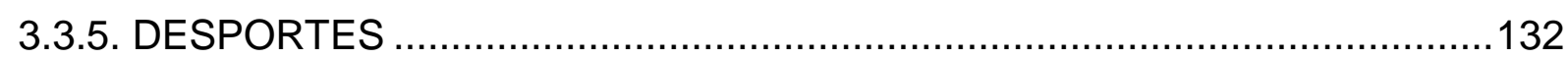

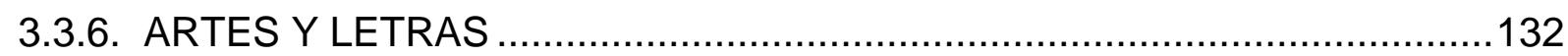

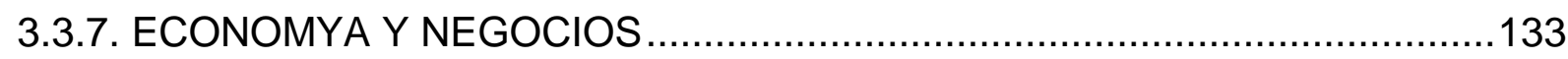

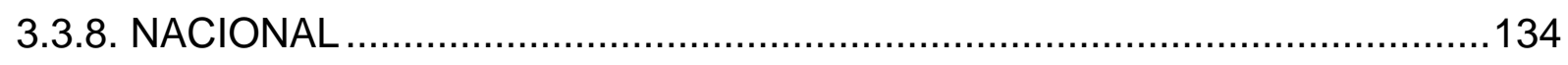

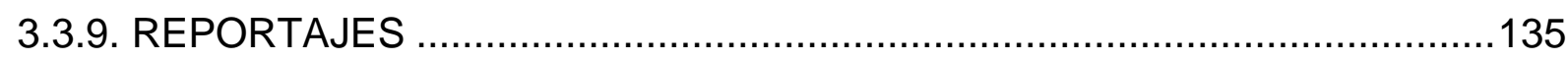

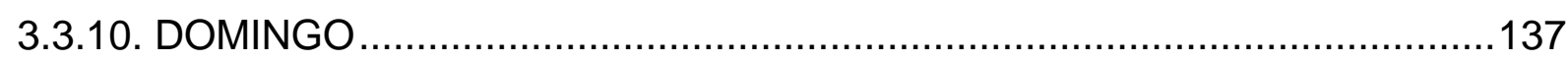

3.4. ANALISANDO E DISCUTINDO OS RESULTADOS …...................................138

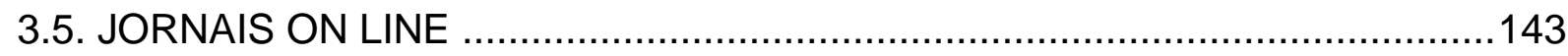

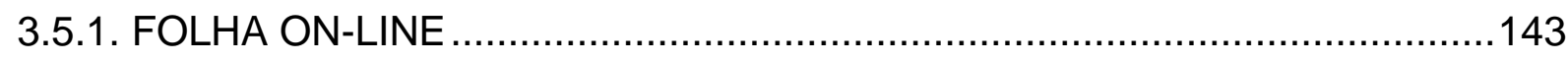

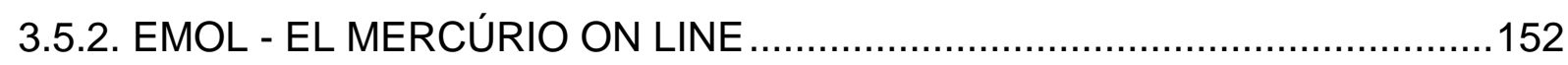

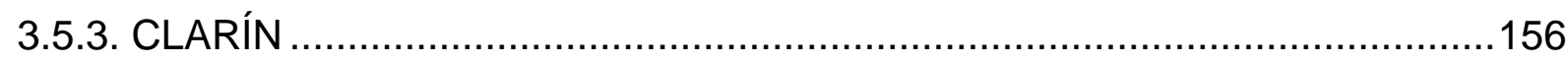

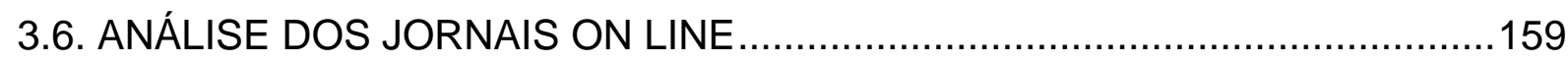

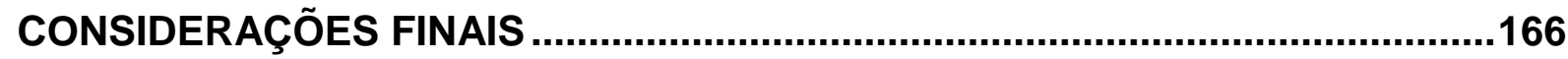

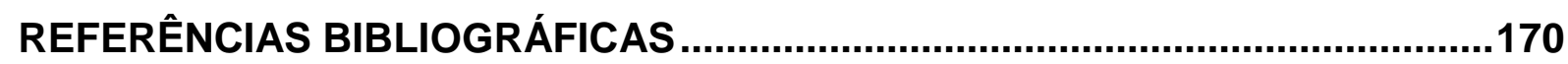




\section{INTRODUÇÃO}

O idioma é um dos grandes valores do patrimônio histórico das nações. Obra dos povos que a falam, dos escritores que a recriam, da história que a enriquece no contato com os outros, a língua é a base da relação permanente entre os indivíduos e de relacionamento entre os povos.

As sociedades humanas (umas primeiro que outras) descobriram em tempo que o conhecimento e a informação são peças chaves para se realizarem conquistas de todas as ordens. Descobriram que conhecimento é o capital abstrato de que dispomos para conquistar inúmeros outros capitais, inclusive o financeiro, e também para impor dominação. Nessa ordem de raciocínio, podemos entender como a área de conhecimento lingüístico e a língua que supostamente falamos foram transformadas em saberes escolarizados.

Inúmeros foram os motivos que levaram as sociedades humanas a se apossarem de algumas áreas de conhecimento e de as transformarem em saberes escolarizados. Dessa forma, a maioria desses motivos surgiu da necessidade de se manipularem e subjugarem grupos sociais desfavorecidos. Assim, levar um saber a um grupo social qualquer era (e de certa forma ainda é, embora tal idéia venha revestida de discursos politicamente corretos) antes de tudo analisar a viabilidade e vantagens políticas e econômicas desse "investimento" para um Império ou para o Estado.

Era muito difícil que uma medida assim partisse de interesses humanísticos em democratizar o saber para que todos pudessem dispor, senão do mesmo capital financeiro, pelo menos das mesmas oportunidades de conhecimento. Se, na América do Sul, falamos hoje o português e o espanhol, ou pelo menos temos essas 
línguas como oficiais, é porque houve grande interesse político e econômico para que isso fosse feito. Afinal, tinha-se a "fé e o império a dilatar" e isso não poderia ser realizado com sucesso sem a imposição da língua do colonizador ${ }^{1}$. (LEÃO, 2001)

Embora em menor grau, ainda hoje vamos à escola para aprender que existe uma forma correta de falar o português, que existe uma norma padrão que deve ser respeitada e pela qual podemos tolher ou estigmatizar qualquer forma de expressão em outras normas lingüísticas.

Entretanto, o domínio da técnica escrita não pode dar-se a custo de coerção e censura lingüística. No processo de construção de uma sociedade letrada, precisamos estar atentos ao aspecto social intrínseco às normas lingüísticas para que, em sociedades altamente estratificadas como a nossa, não haja sobreposição social e lingüística. Nossas práticas pedagógicas precisam atender às necessidades de todos os grupos sociais, ricos ou pobres.

O falante que atua na sociedade espalhando o preconceito lingüístico é, na maioria das vezes, vítima da cultura lingüística na qual está inserido. Esse falante age com as armas preconceituosas que Ihe foram dadas pela escola ou adquiridas em seu meio de socialização, por isso se sente à vontade para fazer piada de suas diferenças lingüísticas ou ainda para usar dessas diferenças para excluir outros. Criticar esse falante, no entanto, não deve ser nosso objetivo, porque as raízes dessas atitudes lingüísticas estão encravadas na essência social da linguagem. A língua e a linguagem são livres, mas em alguns casos a sociedade é que as aprisiona e as corrompe conforme seus interesses.

\footnotetext{
1 Sempre foi máxima inalteravelmente praticada em todas as nações que conquistaram novos domínios, introduzir logo nos povos conquistados o seu próprio idioma, por ser indispensável, que este é um meio dos mais eficazes para desterrar dos povos rústicos a barbaridade dos seus antigos costumes e ter mostrado a experiência que, ao mesmo passo que se introduz neles o uso da língua do colonizador, que os conquistou, se lhes radica também o afeto, a veneração e a obediência ao mesmo povo.
} 
Portanto, essa dissertação tem como objetivo principal analisar a integração de anglicismos na América do Sul, mediante pesquisa em jornais de grande porte, e desenvolver uma crítica sólida a todos os responsáveis pela difusão de descobertas atuais e científicas nos estudos lingüísticos que colaboram com o preconceito lingüístico reproduzido nos meios de comunicação e, conseqüentemente, na cultura.

Devemos agir, se possível, como sociolingüistas militantes (mas não dogmáticos) como sugere Bagno (2005, p.7), para quem "não basta apenas descrever e analisar as relações entre língua e sociedade porque é preciso também transformá-las".

Nos últimos anos, têm surgido movimentos em defesa da nossa língua portuguesa - "pura" e soberana -, alegando-se até mesmo falta de patriotismo.

Conforme Faraco \& Tezza (2002), ao estudarmos a história das línguas, percebemos que elas se enriquecem pelo contato mútuo, não havendo nenhum caso de língua descaracterizada pelo contato com outras diferentes. Cria-se um processo denominado hibridização, que ocorre com a própria cultura. Como língua, cultura e sociedade estão interligadas, é natural que ocorra a hibridização vocabular. Não existem línguas estáticas, elas estão em constante movimento e transformação.

Faraco \& Tezza (2002) ainda complementam que a entrada ininterrupta de palavras estrangeiras na língua portuguesa não afeta em nada a sua estrutura gramatical. Ou seja, as línguas são abertas ao enriquecimento contínuo dos seus vocabulários, sendo somente fechadas em sua organização gramatical.

No caso do inglês, incorporamos, nos últimos 100 anos, desde o vocabulário do futebol, até a terminologia da informática e do setor financeiro. Há um cálculo que estima em sete centenas as palavras de origem inglesa presentes no português. É 
interessante destacar que o vocabulário do português tem algo em torno de 500 mil palavras. (Faraco \& Tezza, 2002, p.35).

Diante desse quadro, Alves (2000) nos diz que a modificação constante de vários aspectos em nossas vidas devido à evolução da ciência, por exemplo, acarreta a transformação do idioma. Novos conceitos, concepções, modos de pensar, técnicas, equipamentos, tudo isso implica também a necessidade da criação de novas denominações. E, mesmo que estas novas denominações advenham da língua inglesa, se elas forem mais adequadas, não há por que não empregá-las.

Em certos contextos, a tentativa de substituição de um estrangeirismo por expressão equivalente em português gera confusão. Imagine-se quão complicado seria no momento de tirar uma fotografia, por exemplo, pedir às pessoas que são fotografadas que não pisquem os olhos porque será utilizada uma "iluminação instantânea de forte intensidade", em vez de dizer simplesmente que se vai usar um flash. (Alves, 2000, p.10).

Não se pode negar que o fenômeno existe; o que mais se faz hoje em dia é surfar, criar um blog ou fazer marketing. Mas isso não significa o desaparecimento da língua portuguesa. Empréstimos lingüísticos aparecem como um fato social e sempre existiram. Hoje, pouca gente sabe disso, mas avalanche, alfaiate, tenor e pingue-pongue são palavras de origem estrangeira, mas já se neutralizaram e certamente não são vistas como ameaça. Perini diz que "não há o menor sintoma de que os empréstimos estrangeiros estejam causando lesões na língua portuguesa; a maioria, aliás, desaparece em pouco tempo, e os que ficam se assimilam". (PERINI, 2006, p.13).

Segundo Bagno (2005), os anglicismos, na virada do terceiro milênio, não têm a força destruidora tão temida pelos puristas e conservadores. E a avalanche de 
palavras estrangeiras tem de ser analisada sob a perspectiva da dependência político-econômica (e conseqüentemente cultural) do Brasil para com os centros mundiais de poder. Não adianta bradar contra a "invasão" de palavras na língua portuguesa sem analisar essa dependência. É querer eliminar os efeitos sem atacar as verdadeiras causas.

Os empréstimos lingüísticos são freqüentes e importantes para a composição do sistema lexical de qualquer língua. O português e o espanhol, como as demais línguas, sofreram e continuarão recebendo interferências de outras línguas, assim como também contribuíram para enriquecer outras com as que, em algum período histórico, entraram em contato; porém, nos últimos séculos, algumas línguas, devido ao grande desenvolvimento econômico, cientifico e tecnológico, interferiram de forma avassaladora em outras línguas, impondo seus valores e com eles os elementos lingüísticos que os acompanham.

A grande penetração cultural e lingüística exercida pela França em outros idiomas no século XIX foi substituída pelo inglês. A expansão e progresso econômico dos países de fala inglesa, principalmente os Estados Unidos, interferiu também lingüisticamente no português e no espanhol.

O papel internacional da língua inglesa hoje é fundamental, tanto na globalização da economia e da tecnologia, quanto na discussão com os Estados Unidos. Podemos, pois, dizer que o poder da língua inglesa está provocando uma divisão entre as línguas do mundo - de um lado, o inglês, a língua franca, e do outro, todas as demais línguas.

É indiscutível o valor dos estrangeirismos como fator de ampliação lexical para as línguas vivas, sem contar que esse é um processo natural e que acontece ao longo da história de todas as línguas que já existiram e existem. Não há língua 
tão isolada ou homogênea, que nunca tenha recebido contribuições de outra(s) língua(s).

As línguas vivas nunca ficam estacionárias, isto é, as línguas são o produto de mudanças e continuam a mudar durante todo o tempo em que são faladas. Em uma sociedade altamente técnica e complexa como a nossa, há uma necessidade constante de novas unidades lexicais - os neologismos - que são criados a partir de uma nova necessidade, podem ser combinados a partir de unidades lexicais já existentes para formar outras mais complexas, pode-se obter um termo novo a partir do uso de um já existente com novo significado - essas duas tidas como mutação interna ou pode-se ter novos termos por influência de outras línguas, tida como mutação externa - por estrangeirismos, fenômeno lingüístico muito comum e que, provavelmente, nenhuma língua está completamente livre de formas emprestadas. (LANGACKER,1972, p.185).

A recepção de termos estrangeiros de uma língua por outra pode se dar através do contato entre línguas - ocorre quando um país que fala uma língua faz fronteira com um país que fala outra língua - como é o caso da França, que está próxima ao Reino Unido, onde o idioma oficial é o inglês, o que levou o francês a receber bastante interferência dos anglicismos.

No caso do Brasil, a interferência dos anglicismos aparece devido a outros fatores, considerando que a língua inglesa nos chega juntamente com o comércio, a ciência, a tecnologia, a informática, os eletroeletrônicos, a mídia, a cultura popular (a festa do halloween) e o entretenimento (o cinema e a música) dos americanos. Assim ocorre com a língua portuguesa e com outras línguas em diferentes pontos do mundo, que também estão recebendo diversos anglicismos.

A maioria dos termos técnicos da web utilizados em todas as línguas do mundo são provenientes da língua inglesa. Essa é uma dimensão significante do 
uso de anglicismos nas mais diversas línguas mundiais. Entretanto, isso pode mostrar uma certa perda da capacidade que as línguas têm de criar novos termos e expressões nativas para representar novas realidades, ou talvez um certo comodismo, já que a opção pela adoção parece ser mais cômoda.

Esses aspectos contribuem para a abrangência do uso dos anglicismos e chega a preocupar alguns estudiosos de línguas por todo o mundo. O inglês está sendo adotado, cada vez mais, por falantes de todas as outras línguas, juntamente com a cultura americana, embora, em muitos casos, essas palavras estrangeiras, ao serem recebidas por outras línguas, sofram adaptações de acordo com a língua receptora, seja na grafia ou nos campos fonético, semântico e gramatical.

Vale enfatizar que as palavras estrangeiras vindas do inglês e recebidas por outras línguas demonstram claramente um fenômeno de comportamento: a globalização desterritorializa fronteiras e enaltece o mercado que mais produz, ou seja, o que é norte-americano é aceito por outras culturas como sendo o melhor. Isso faz da língua inglesa uma língua privilegiada, dada a sua origem, e torna privilegiado, também, quem faz uso dela. Com isso, os falantes não vêem na integração dos anglicismos uma ameaça à sua língua.

$\mathrm{Na}$ língua portuguesa, o fenômeno dos anglicismos tem ocorrido com muita intensidade, embora o Brasil só faça fronteira com um país que fala o inglês (Guiana Inglesa), mas que não faz qualquer diferença, dada a pequena extensão do país e o inexpressivo contato devido à baixa densidade populacional.

A intensidade de ocorrências de anglicismos nos idiomas português e espanhol é resultado de um processo político, econômico, social e cultural, e que tem, na Internet, um fator favorável - a língua inglesa é a língua da informação e da informatização. 
A quantidade de anglicismos usados em nosso dia a dia é muito grande, embora não sejam eles os únicos empréstimos da língua portuguesa ao longo de sua história, como já pudemos mostrar, e que, por certo, não serão os últimos, já que empréstimo é um processo natural e que diz respeito a qualquer língua viva.

Há, por algumas razões, um movimento organizado para hostilizar os anglicismos. Mas os resultados dessas tentativas de reduzir o uso de anglicismos são bem conhecidos - os falantes comuns, sobretudo os jovens, continuam usando anglicismos, embora, algumas vezes, apareça na própria língua, termo de igual significado. Os termos do inglês continuam tendo a preferência, mais particularmente em algumas áreas como economia, marketing e informática.

O uso de anglicismos também se apresenta como modismo, decorrente de um desejo que algumas pessoas têm de demonstrar refinamento; outras desejam demonstrar que estão atualizadas, na moda. Isso reflete a intervenção científica e tecnológica norte-americana sobre a brasileira, bem como uma intervenção de caráter ideológico. A comunidade vai assimilando mais elementos com base nos costumes e modo de vida do povo dos Estados Unidos. O falante toma tal país como modelo, imitando-o primeiramente pela língua.

Os Estados Unidos são um país de grande poder político-econômico e cultural, reconhecido como exportador de bens de consumo, de pesquisa científica, de tecnologia, de multinacionais, de música, de cinema, de moda, de alimentos etc. Toda essa influência se reflete no léxico, com mais intensidade, com o advento da Internet, que nos tem trazido, com a velocidade da luz, a língua inglesa por meio da informação. Com essa mesma rapidez, é conferido, a cada termo do inglês que aqui chega grande importância e preferência, pois os mesmos traduzem 'status', isto é, uma representação social prestigiosa para quem os usa. 
Tal aspecto verifica-se nos adolescentes brasileiros. $O$ emprego de anglicismo demonstra a admiração e a imitação de modelos estrangeiros em todos os setores. São eles que, em grande maioria, freqüentam os 'sites' da Internet, trocam idéias nos 'chats', tem 'flogs 'e 'blogs', curtem músicas de 'rock', atualmente 'hip-hop', comem 'hamburgers', bebem 'milkshake', assistem a filmes 'trash' e usam gírias como 'nerd'. A grande influência do modo de vida americano reflete-se especialmente na linguagem.

Esses usos são decorrentes da relação entre língua, cultura e sociedade. Os falantes decidem o que utilizar em razão de fatores culturais e sociais. E, muitas vezes, um termo estrangeiro, devido a sua grande aceitação e uso, nem sempre soa como estrangeirismo, como é o caso de jeans, show, hamburger e outros.

O intercâmbio entre comunidades lingüísticas diferentes, hoje tão facilitado pela informatização da informação, repercute no contato entre as línguas, o que favorece o enriquecimento do léxico, através da adoção de palavras estrangeiras, como destaca Froehlich:

A história dos empréstimos é principalmente uma amostra ou um índice do desenvolvimento cultural de determinado povo; de suas conquistas culturais. Cada empréstimo encerra em si toda uma história de descobertas... Especialmente nos nossos dias presenciamos o surgimento de um grande número de empréstimos de muitos tipos, que surgem, não de um único povo ou cultura, mas praticamente de quase todos os povos e culturas, o que significa que o ser humano deixou de ser estritamente nacionalista, para se transformar em internacionalista. (1980, p. 91).

Rajagopalan (2004, p.12) observa que o inglês está presente em todos os lugares - em anúncios de neon, vitrines de lojas, comerciais de televisão, jornais e revistas populares e em camisetas usadas pelo povo. São os comerciais de 
televisão, a música, a Internet, os esportes e as camisetas que mais atingem os adolescentes. Para ele, o inglês infunde uma aura adicional ao produto que está sendo comercializado, em especial, acrescenta algo de moderno, o que chama atenção dos mais jovens.

Aportuguesar as palavras pode ser bonito e muito mais fácil. Talvez esta ação a princípio seja algo corriqueiro e que não afete em nada as nossas vidas, entretanto deve-se prestar atenção se este aportuguesamento pode ou não levar a uma outra situação, não neste momento, mas futuramente. $O$ presente trabalho visa a conhecer algumas dessas palavras e discutir se este aportuguesamento poderá afetar ou não a nossa língua, podendo ser até extinta.

O léxico do português foi formado de empréstimos do árabe, das línguas germânicas, do italiano, do espanhol, do francês, das línguas africanas, das línguas indígenas etc. Entre os intercâmbios lingüísticos, pode-se dizer que o português não só recebeu influência estrangeira como também influenciou outras línguas. 


\section{IDIOMAS}

\subsection{INTERCÂMBIO LINGÜÍSTICO}

As línguas são sistemas abertos. Como qualquer organismo vivo, dotado de capacidade reprodutiva e em contínua elaboração, substituem, aquém e além fronteiras, termos que perderam vitalidade por novas formações, em função das novas exigências dos falantes e das novas realidades político-sociais.

Porém, seguindo a relação entre língua e cultura - e contrariamente aos que consideram que certas línguas não têm possibilidade de exprimir conceitos abstratos - Herder (1987) afirma que as palavras que designam abstrações são possíveis em todas as línguas, desde que as comunidades que as falam tenham necessidade delas.

Os fenômenos de intercâmbio lingüístico entre diferentes idiomas sempre existiram e têm tido um papel importante na evolução das línguas, refletindo em nível lingüístico as interações históricas entre populações e culturas diversas.

Como escreveu Nunes de Leão (2001, p. 64), “os conceitos dos homens são infinitos e as palavras finitas (...) e há nas línguas alheias alguns termos que não há na nossa para declarar o que sentimos ou ensinamos".

Toda língua, desde sua origem, incorpora elementos léxicos derivados de outras comunidades lingüísticas, que assim colaboram com a transformação e o desenvolvimento da língua como elemento de interação social, cultural e política.

Assim também ocorre com a Língua Espanhola, que recebeu elementos das línguas pré-romanas, do árabe, do francês, das línguas germânicas e indígenas da 
América entre outras. Agora é o inglês que deixa sua contribuição, acrescentando anglicismos ao vernáculo espanhol, o que é notado pelo usuário como uma marca de modernidade e prestígio.

No século XVIII, o inglês passou a exercer certa influência sobre as línguas européias, graças à imprensa inglesa e, mais tarde, também por razões de prestígio social. Assim, muitas expressões inglesas entraram em idiomas como espanhol, português e italiano. Mas no século XX, especialmente depois da Segunda Guerra Mundial, a influência do inglês, ou seja, do anglo-americano, impôs-se com força arrebatadora na cultura, na vida cotidiana, na moda e, em conseqüência, também nas línguas de outros países.

Não somente a crescente hegemonia política, econômica e militar dos países de língua inglesa, mas também a difusão de costumes, moda e produtos procedentes dos Estados Unidos da América contribuíram para a penetração, não apenas no português e no espanhol, mas em várias línguas européias, de um número cada vez maior de elementos lingüísticos anglo-saxões.

Aumentaram assustadoramente, quando em comparação a séculos anteriores, os meios de penetração pelos quais os estrangeirismos se introduzem em uma língua. Nos séculos XVIII e XIX os estrangeirismos viajavam quase que exclusivamente através dos livros, ou seja, sua influência chegava, de fato, somente aos intelectuais e às classes sociais ricas e instruídas, que tinham possibilidade de ler ou viajar ao exterior. Assim, os elementos lingüísticos estrangeiros se estabeleciam gradualmente na língua culta. Apenas mais tarde, este processo chegava a tomar parte de maneira efetiva da linguagem cotidiana e da fala comum. As classes inferiores conservavam o idioma como falado por seus pais, sofrendo pouca ou nenhuma influência externa. 
Para John Lyons (1981), tomar emprestado lexemas de outras línguas é uma maneira de ampliar o sistema lingüístico. Lyon defende a idéia de que a ampliação do vocabulário de uma língua por meio de empréstimos e a modificação do significado de palavras existentes por meio de uma tradução por empréstimos envolvem mudanças na estrutura lexical do sistema lingüístico.

Segundo Nelly Carvalho (1989), os empréstimos lingüísticos são tão antigos quanto à história da língua, ou melhor, quanto à própria língua. Para ela o empréstimo não constitui uma criação lingüística, pois a novidade do mundo extralingüístico não apareceu de acordo com a criatividade do falante.

O fenômeno de tomar palavras emprestadas de outras línguas é perfeitamente natural e a língua portuguesa sempre lidou com a importação de palavras.

Como o uso de termos oriundos de línguas estrangeiras é sempre uma conseqüência e não uma causa, esse fenômeno denuncia duas situações que são características da nossa língua: dependência de outras culturas, seja pela questão econômica e/ou tecnológica, seja pela influência de comportamentos culturais; ou que essa mesma língua portuguesa não seja veículo de cultura uniforme, já que Portugal, Brasil e países lusófonos na África não têm uma atitude comum em relação aos empréstimos lingüísticos.

Para Haugen (2000), o empréstimo é uma tentativa de reproduzir numa língua os padrões lingüísticos já existentes em outras. O empréstimo é uma conseqüência do contato entre as línguas.

Sem dúvida, as profundas transformações sociais e econômicas ocorridas em todo o mundo no século XX contribuíram com a propagação de estrangeirismos. $A$ difusão dos meios de comunicação de massa facilitaram, durante as últimas 
décadas, a alfabetização da maior parte da população, fazendo com que as informações, e com elas a língua, circulem rapidamente por todas as classes sociais e por todo o país. As inovações técnicas e científicas introduziram uma grande quantidade de novas idéias e novos objetos na vida cotidiana e a ampliação do comércio mundial vem difundindo de maneira massiva os nomes das empresas e dos produtos procedentes dos EUA, sempre com seu nome original.

\subsection{LINGUAGEM E IDENTIDADE SOCIAL}

A língua é um bem comum a todos, determinante territorial e cultural de um povo. Não podemos pensar em língua melhor ou pior, língua superior ou inferior num

país onde a diversidade lingüística é tão marcante. A língua constitui-se em uma atividade essencialmente social. $O$ fato de a língua ser condicionada e modelada pela realidade social e cultural faz dela também um instrumento político.

Nenhuma outra característica distingue tão bem o homem dos outros animais como o domínio da linguagem. Ela tem sido o eixo central do desenvolvimento social e cultural da humanidade.

A língua resulta da interação das capacidades cognitivas e emocionais do homem e das orientações comportamentais que Ihe são transmitidas pelo contexto social.

Através da língua materna, o indivíduo estabelece a sua relação com o mundo; ela é veículo, ligação e fator de construção da sociedade e da cultura em que está inserido. É a língua, também, que permite ao indivíduo um posicionamento no momento presente, sendo ela igualmente um repositório de memórias coletivas. Deve, portanto, entender-se a língua como um fator de identificação cultural que 
congrega os indivíduos pertencentes a uma determinada comunidade, povo ou nação.

Se a concretização da língua se faz através da produção lingüística individual, também a identificação cultural é a realização, para cada pessoa, de uma determinada cultura abstratamente considerada. Assim, essa realização está intimamente ligada aos hábitos, crenças, atividades artísticas, relações parentais e sociais do meio restrito em que o indivíduo está inserido. Não se pode, portanto, entender que a identificação cultural tenha, como referentes, as formas que assume a cultura em todo o espaço onde se falam as diferentes variedades de uma mesma língua.

A atividade lingüística de cada indivíduo contribui poderosamente para reconhecer a si próprio e para ser reconhecido pelo outro. É, na realidade, um fator de identificação cultural, mas no uso, e pelo uso que dela faz o indivíduo e não apenas por pertencer a uma das várias comunidades que a utilizam como materna.

A importância dos processos comunicativos nas sociedades urbanas e industriais revela-se na habilidade do falante em usar a sua língua para interagir com seus semelhantes, comunicando seus pensamentos, sentimentos e ações por meio de um sistema de signos vocais - a língua. Como o ser humano dispõe de inúmeras possibilidades para comunicar-se, cada língua corresponde à expressão de uma escolha entre as várias possibilidades lingüísticas, apresentando variações relevantes em função de valores sociais, regionais, de faixa etária, de situação econômica etc.

A língua como um sistema de possibilidades oferece um conjunto flexível no que diz respeito às regras de seleção, combinação e substituição, sem comprometer ou alterar a interação. É o que entendemos por variação lingüística. 
Não há hierarquia entre os usos variados da língua, assim como não há uso lingüisticamente melhor que outro. Em uma mesma comunidade lingüística, portanto, coexistem usos diferentes, não existindo um padrão de linguagem que possa ser considerado superior. As pessoas não falam do mesmo modo e até uma mesma pessoa não fala sempre da mesma maneira.

Todo ato de fala é um ato de identidade. A linguagem é o índice por excelência da identidade. As escolhas lingüísticas são processos inconscientes que o falante realiza e está associado às múltiplas dimensões constitutivas da identidade social e aos múltiplos papéis sociais que o usuário assume na comunidade de fala. O que determina a escolha de uma ou outra variedade é a situação concreta de comunicação.

É possível dizer que a educação lingüística de cada indivíduo começa logo no início de sua vida, quando, em interação com a família, adquire a língua materna. Neste processo, que prossegue ao longo de toda a infância e mesmo além, a pessoa vai aprendendo as normas de comportamento que regem a vida dos diversos grupos sociais, cada vez mais amplos e variados, em que ela vai ser chamada a se inserir. Ninguém negaria que há diferenças no comportamento e no uso da língua entre os grupos sociais que se formam ao longo desse processo; a língua em si mesma é um importante meio de manutenção da identidade do grupo, como já foi dito.

A história da colonização do Brasil mostra o processo de formação da nossa língua à luz dos aspectos mais marcantes para a diversidade lingüística presente em nosso território, um país monolíngüe. Por exemplo, a língua trazida para o Brasil pelos portugueses conservou-se bem semelhante à moda lusitana, nos grandes centros de colonização no litoral, onde havia constante intercâmbio comercial e 
cultural com a metrópole, distinguindo-se dela, porém, em alguns traços. Com relação aos vernáculos rurais, observa-se um maior distanciamento da norma portuguesa, pois nessa modalidade, possivelmente, foi mais acentuada a influência das línguas indígenas e dos falares dos negros que vinham para o Brasil dominando ou não o dialeto crioulo que já se instituíra na África, em colônias também portuguesas.

A atribuição de prestígio a uma variedade lingüística decorre de fatores de ordem social, política e econômica. Ao longo de toda a história brasileira, o português falado pelas classes mais favorecidas tem sido a variedade prestigiada em detrimento da todas as outras: é a chamada norma-padrão ou língua-padrão, é a que foi eleita como representativa de um país, e é ensinada e aprendida na escola.

Quando uma variedade de língua é eleita variedade padrão, ela ganha alta condição social (status) e passa a ser instrumento de dominação sobre as demais variedades, que passam a ser consideradas inferiores, devido a uma visão preconceituosa, perpetuada, de alguma maneira, por meio das regras impostas pela gramática da língua escrita, que legitima a linguagem padrão como única.

De acordo com estudiosos dos contatos de idiomas, a interferência lingüística pode afetar diversos níveis: fônico, morfológico, sintático, léxico e semântico. Sem dúvida, à medida que prosseguia a análise das situações de contato entre duas línguas, alguns autores observaram a existência de fenômenos de interferência que não se encaixavam nos níveis tradicionais. Tratava-se, na maior parte dos casos, de traduções literais ou traçados de unidade ou estruturas pertencentes à fala ou sistema idiomático-regulador, e não de traçados sintáticos claramente detectáveis no sistema lingüístico. Além disso, estes fenômenos se dão tanto na fala espontânea como em situações mais elaboradas e diferentes de contato entre os idiomas, como 
é o caso das traduções e dublagens cinematográficas. Desde âmbitos diversos (interferências, lingüística contrastiva, estilística comparada, tradutologia), os pesquisadores buscaram uma explicação coerente destes fenômenos.

A interferência pragmática ocorre naturalmente na fala de imigrantes bilíngües que tentam internalizar os padrões culturais e lingüísticos, classificando uma língua estrangeira como socialmente superior. Na grande maioria dos estudos realizados, esta língua superior é o inglês. Portanto, de acordo com a terminologia consolidada no âmbito norte-americano estão os estudos de Weinreich (1953) (1968), o termo mais adequado para descrever este fenômeno é a interferência; e, neste caso, interferência pragmática.

No entanto, em situações de empréstimo cultural entre línguas da cultura européia, pode ocorrer interferência pragmática, de uma maneira um pouco mais artificial, e muito menos intensa, em situações de contato que reproduzam alguns dos principais fatores-chave do bilingüismo oral comum: tradução literal de um modelo estrangeiro e conversa quotidiana.

Teoricamente, é possível aumentar e diversificar o léxico a partir do vernáculo de uma língua, sem precisar importar palavras de outras comunidades. Porém, quando a língua pertence a países onde o avanço da ciência e tecnologia permite um poder econômico maior que o de outros, isso os obriga à importação de produtos provenientes dessa tecnologia, comprados, também, com o nome original. A aceitação de tal "transação lingüística" traz o nome da modernidade e do prestígio adquiridos junto com o produto.

Desta forma, o neologismo por empréstimo tem duas faces, a potência e a impotência. A potência daquele que produz e vende, e a impotência de quem não produz e consome. Neste processo, tem especial importância o léxico tecnológico 
especializado, principalmente o da informática e da internet, por incorporar-se ao cotidiano das pessoas com tal rapidez, que mal é conhecido e já passa a ser usado em diferentes contextos, nem sempre especializados.

A dificuldade na aceitação do vernáculo muitas vezes está relacionada ao preconceito que existe no mundo hispânico quanto ao que é nacional. Existe o mito de que "o que vem de fora é melhor". Por conseguinte, a assimilação de estrangeirismos é freqüente no espanhol e no português de hoje, de forma que a subvalorização cultural desencadeia subserviência ideológica e dependência lexical.

\subsection{MERGULHANDO NA TEORIA}

Labov (1982, p. 16) diz que "o objeto da descrição lingüística é a gramática da comunidade de fala: o sistema de comunicação usado na interação social." Ele assume que a língua é o objeto de descrição da lingüística, mas, ao contrário de outros lingüistas, ele acredita que essa língua não pode ser criada em laboratórios, ou tomada a partir de um único indivíduo, um idioleto. A língua que Labov propõe para a descrição lingüística é a língua da comunidade de fala, a língua da interação social, o sistema de comunicação que não pode ser estudado separadamente daquilo que o constitui, a sociedade.

Labov é responsável pelo desenvolvimento de uma concepção de língua que não nega o aspecto social da linguagem, que vai a campo para atestar e observar na heterogeneidade lingüística a própria condição da linguagem. É com Labov que a sociolingüística começa a ser respeitada e a heterogeneidade lingüística e a influência dos fatores sociais passam a ser estudadas com maior rigor metodológico. 
Uma nova concepção de língua orienta, conseqüentemente, uma nova forma de pensar o ensino da língua. Com o avanço de estudos sociolingüísticos, pensar o ensino da língua, hoje, envolve também uma reflexão fundamental sobre a dinâmica existencial da língua, sobre os condicionadores sociais que levam a variações e mudanças lingüísticas.

A grande crítica de Labov ao modelo saussuriano e chomskiano é baseada no fato de estes modelos se dedicarem exclusivamente à contemplação de seus próprios idioletos (Monteiro, 2000) e de não abrirem perspectivas a análises lingüísticas de enfoque social.

A idéia de que existe um falante-ouvinte ideal e de que as comunidades lingüísticas são homogêneas não se sustenta, e a cada situação de fala é possível perceber que a língua falada é, a um só tempo, heterogênea e diversificada. A proposta da sociolingüística é de buscar a sistematização dessa heterogeneidade.

A concepção heterogênea de língua defendida por Labov é resultado da assunção definitiva do aspecto social da linguagem, que traz em seu bojo o estudo dos diversos condicionadores sociais que operam na variação e mudança lingüística. Como lembra Monteiro (2000):

A heterogeneidade lingüística reflete a variabilidade social e as diferenças no uso das variantes lingüísticas correspondentes às diversidades dos grupos sociais e à sensibilidade que eles mantêm em termos de uma ou mais normas de prestígio. (MONTEIRO, 2000, p.58)

Por esse ponto de vista, a variação lingüística é um processo natural na língua e está fortemente condicionado socialmente. A língua só dá conta desse processo porque é heterogênea e opera com regras variáveis. 
Juntamente com a concepção heterogênea de língua, surgem as noções de regra variável, variáveis e variantes sociolingüísticas. Sabe-se que em uma língua são freqüentes e numerosas as formas em variação e, num olhar diacrônico, são também freqüentes as formas que mudam ou desaparecem. Mas, como lembra Monteiro (2000, p.58), é óbvio que nem todos os fatos da língua estão sujeitos a variações.

Conforme Labov (1972):

Nós podemos definir uma variável sociolingüística como aquela que está correlacionada com algumas variáveis não lingüísticas do contexto social: como o falante, a quem se fala, a audiência, as condições, etc. (tradução do autor) (LABOV,1972, p.237)

As formas que se encontram em variação (que podem ser duas ou mais) chamam-se variantes lingüísticas, que, na definição de Labov (1972), devem conter o mesmo valor de verdade e se apresentar em um mesmo contexto. Representam assim maneiras diferentes de dizer a mesma coisa, por isso estão em luta constante.

Dessa forma, podemos dizer que os pronomes de primeira pessoa do plural (de agora em diante P4) do português falado no Brasil são uma variável lingüística cujas formas variantes são nós e a gente. Segundo Monteiro (2000, p.59), "duas formas distintas de se transmitir um conteúdo informativo constituem uma variável lingüística”.

A língua dá conta dessas variações porque opera com um sistema de regras variáveis que, como diz Monteiro (2000, p.58), "aplicam-se sempre quando duas ou mais formas estão em concorrência num mesmo contexto".

Um dos conceitos pertencentes à lingüística gerativa de Chomsky bastante criticado pela sociolingüística é o conceito de competência lingüística; primeiro 
porque se remete a uma competência lingüística que seria concebível sem interferência de fatores sociais; segundo porque se baseia na língua de um falanteouvinte ideal inserido em uma comunidade de fala homogênea. Ou seja, para a sociolingüística não existe falante-ouvinte ideal, não há comunidades lingüísticas homogêneas e nem mesmo seria possível se tornar competente em uma língua sem que se considerasse seu aspecto social, dada a própria condição social da linguagem.

Uma vez que a concepção teórica de competência lingüística, no sentido chomskiano, como observa Monteiro (2000), não expressa a enorme complexidade de um sistema lingüístico em suas várias dimensões, abrangendo no máximo as áreas da gramática e da fonologia, fez-se necessária a introdução de um novo conceito: competência sociolingüística.

A competência sociolingüística implica não só a identificação e compreensão da natureza de contextos sociais, mas principalmente a habilidade de atuar lingüisticamente nestes contextos, diferenciando, entre outras coisas, formas e variedades lingüísticas apropriadas a cada contexto social.

Nossa competência sociolingüística nos orienta em um "monitoramento" social da linguagem, que nos permite pensar sobre palavras ou frases adequadas a determinados contextos, sobre expressões que especificam atitudes como autoridade, respeito e cortesia; leva-nos a considerar quando algo pode ser dito; onde pode ser dito e como pode ser dito. Nossa competência sociolingüística nos ajuda também a distinguir entre o papel social de expressões usadas por outras pessoas, assim como o próprio papel social das pessoas envolvidas em uma conversa. 
A competência sociolingüística de um falante se constitui em uma competência importantíssima, que pode e deve ser desenvolvida, entre outras competências comunicativas, através do ensino da língua nas escolas, de forma que os alunos saibam atuar lingüisticamente em todas as esferas sociais e em todos os meios de comunicação oral e escrita, uma vez que é isso que a sociedade demanda.

A pessoa que tiver sua competência sociolinguisticamente desenvolvida deverá se sentir mais à vontade face às exigências sociais e, principalmente, deverá relacionar-se bem com as diferenças lingüísticas e com sua própria identidade sociolingüística, assumindo-a publicamente, com autoridade e segurança lingüísticas.

\subsection{ANGLICISMO E ESTRANGEIRISMO}

Muitas pessoas repudiam estrangeirismos provenientes de idiomas modernos, mas palavras recém-incorporadas do latim e do grego antigo geralmente são muito bem recebidas. Além de questões culturais, como o orgulho nacional, uma das causas é a facilidade de adaptarmos palavras do latim e do grego às ortografias e pronúncias do português, enquanto com o inglês o processo é mais complicado.

Estrangeirismo é o uso de palavra, expressão ou construção estrangeira no lugar de equivalente vernácula.

Empréstimos, por outro lado, são palavras de outro idioma, mas ainda não completamente incorporadas ao nosso. Mantêm a escrita e a pronúncia originais, e não são muito difundidas. Na prática, a diferenciação entre estrangeirismos e empréstimos não é tão clara assim. O termo "mouse" foi incorporado ao português no Brasil, mas a pronúncia e a escrita originais foram mantidas. Será que isso 
muda? "Déficit" mantém a grafia original, mas os termos relacionados ao futebol foram adaptados à nossa língua à medida que o Brasil ganhou destaque internacional no esporte.

Segundo Ribeiro e Klein (2007), recebem o nome de estrangeirismo os vocábulos que ainda não fazem parte do acervo lexical do idioma, são sentidos como externos ao vernáculo desta língua. Podemos encontrar facilmente estrangeirismos em vocábulos técnicos, esportes, economia, informática, como também em outros tipos de linguagens especiais, como publicidade e colunismo social.

Sendo o anglicismo um fenômeno tão complexo e variado, não é fácil definir suas características de maneira precisa.

Um anglicismo é um elemento lingüístico que se emprega no espanhol e no português contemporâneo e que tem como origem imediata um modelo inglês. Anglicismo é uma palavra ou expressão proveniente da língua inglesa, mas que é empregada em outras línguas. Os anglicismos, assim como os galicismos, os italianismos, os latinismos etc. constituem, na verdade, empréstimos lingüísticos.

Anglicismos podem ser definidos, ainda, como palavras provenientes do inglês (geralmente usadas no português e no espanhol), seja devido à necessidade de designar objetos ou fenômenos novos, para os quais não existe designação adequada na língua, seja por uma série de motivos de caráter sociológico (ignorância da língua receptora, dificuldades em traduções, aculturação, vontade de parecer "distinto" etc.) que levam à preferência por palavras inglesas, em detrimento das vernáculas.

Segundo Ferreira (1975), o termo anglicismo vem do francês anglicisme, o qual corresponde a toda palavra ou locução inglesa introduzida noutra língua e 
empregada como se desta o fosse. Ainda de acordo com esse mesmo autor, anglicizar um país significa submetê-lo à influência inglesa, o que está preocupando muitos dos nossos gramáticos, e criando litígios entre os que são a favor e os que são contra a anglicização.

O português do Brasil incorporou um número considerável de anglicismos em décadas recentes. Alguns anglicismos foram aportuguesados, outros permaneceram com a sua grafia original. Exemplos: Usos de palavras ou expressões originais da língua inglesa: browser (navegador, leitor de hipertexto); cowboy (vaqueiro; no estilo do Velho Oeste nos EUA): filme de cowboy; drag queen (travesti, homem vestido de mulher); hit (sucesso, grande sucesso: canção que faz sucesso - Música); homecenter (loja enorme para materiais de construções) Loja para venda de vários acessórios para nossa casa; home theather (cinema em casa) Aúdio de qualidade sem precisar de caixas de som,aparelho para reproduzir filmes com ótima qualidade de imagens; home video (vídeo doméstico); link (ligação - em informática): links externos (ligações externas); mouse (periférico de computador, em informática); play (reproduzir, tocar; reprodução: de música ou vídeo); performance" (desempenho): A alta performance de um computador (o alto desempenho de...); piercing (perfuração ornamental: em orelhas, dentes, umbigos etc); pub (cervejaria); ranking (classificação, quadro classificatório); remake (regravação - Música); remix (novo arranjo - Música); shopping center ou apenas shopping (centro de compras); Loja que vende várias coisas como: brinquedos, roupas, acessórios em geral; single (compacto: versão pequena, com 2 ou 4 músicas, dos obsoletos discos LP); site (sítio, em informática); site oficial (sítio oficial); skate (prancha de rodas)Esporte muito radical,que várias pessoas praticam para se divertir na rua. 
Algumas palavras inglesas aportuguesadas, de uso aceito em geral, já incluídas em dicionários: bife (pedaço de carne de gado; de "beef"; no entanto, bife é dito "steak", em inglês, e "beef" é usado em inglês com o sentido de carne bovina); futebol (de football", usado na Inglaterra e em todo o mundo anglofônico, EXCETO nos EUA, onde o futebol que conhecemos é dito como "soccer", e a palavra "football" é traduzida em português como "futebol americano", um tipo diferente do soccer, famoso esporte em que se usa uma bola oval); handebol (jogo semelhante ao basquete; de handball); tênis ou ténis (esporte) (de "tennis"); tênis ou ténis (calçado) (de "tennis shoe"); videoclipe (ou clipe) (de "videoclip");

Alves (1990, p. 79) lembra ainda o fato de que "o emprego freqüente de um estrangeirismo constitui também um critério para que essa forma estrangeira seja considerada parte componente do acervo lexical português". A esse respeito, cita o substantivo jeans, "unidade lexical tão usada contemporaneamente, parece-nos já adaptada à língua portuguesa e manifesta-se, por isso, como um empréstimo ao nosso idioma".

Os estudiosos que nas últimas décadas têm-se ocupado em desenvolver diversas definições e classificações, tentando atingir toda a variedade de seus aspectos, por exemplo, Howard Stone (1957) considera como anglicismos palavras usadas em sua forma inglesa ou derivadas do inglês; palavras que passaram de outros idiomas ao inglês e deste ao espanhol e ao português; ou do inglês ao espanhol através do francês; termos e vocábulos criados por pessoas de fala inglesa e introduzidos no espanhol; palavras usadas em um sentido inglês (empréstimos semânticos ou contaminações); e traduções de tipos, complexos e modismos ingleses. 
Esta multiplicidade está bem resumida na definição formulada por Chris Pratt (1980), uma das mais rigorosas e objetivas, e, por isso, figura entre as mais utilizadas nos estudos posteriores sobre o anglicismo. Esta definição requer algumas observações acerca de alguns termos por ela utilizados. O primeiro conceito importante que ela expressa é a definição do anglicismo como elemento lingüístico, ou grupo dos mesmos.

Quando se fala de anglicismos ou de estrangeirismos em geral, a primeira coisa que vem à mente são as palavras tomadas diretamente de línguas estrangeiras, como os empréstimos puros. Mas as palavras, mesmo sendo manifestações mais evidentes do anglicismo, não são os únicos elementos que migram do inglês para o espanhol e o português. Ao contrário, o fenômeno do anglicismo atinge todo tipo de elemento lingüístico, que pode ser ortográfico, léxico, fonético, morfológico, semântico, sintático. Basta, por exemplo, prestar atenção ao gerundismo, bastante utilizado no inglês e freqüentemente adotado na fala de latinoamericanos, mesmo sendo considerado um modelo inadequado ao português e ao espanhol.

Existem vários motivos para adotar-se um estrangeirismo ou empréstimo. Às vezes não existe palavra adequada, ou esta é desconhecida por jornalistas, tradutores, escritores etc. Em outros casos, a palavra em português é conhecida, mas não é empregada por questões estéticas, de auto-afirmação ou esnobismo. Na informática quase sempre existem palavras adequadas em português, mas as palavras em inglês são mais difundidas pela imprensa, e passam a ser mais bem compreendidas.

O caminho do estrangeirismo ao empréstimo nem sempre é percorrido de maneira previsível. Não se pode exigir que um item lexical estrangeiro apague, de 
um momento para o outro, todo e qualquer vestígio de sua proveniência alógena. Em muitos casos, bem antes disso, esse elemento já estará interagindo com o restante do léxico, colocando-se à disposição dos falantes para novas criações vocabulares ou semânticas. Na verdade, em certas situações, a naturalização completa poderá nem vir a ocorrer.

\subsection{A INFLUÊNCIA DO ANGLICISMO}

Em nosso cotidiano, nos deparamos com uma infinidade de termos ingleses cujos verdadeiros significados em muitos casos nem sabemos ao certo. No entanto, tais termos são repetidos inúmeras vezes, mais por imitação que por pura necessidade.

No passado, o uso de palavras estrangeiras costumava ocorrer quando não existia uma equivalente em português que definisse o que se queria dizer, ou quando se desejava demonstrar cultura ou superioridade em relação àqueles que usavam termos apenas em português. Hoje, o emprego de palavras inglesas misturadas ao português, por exemplo, tem-se tornado cada vez mais comum, parece ter virado moda.

Devido à grande influência econômica e cultural norte-americana, diariamente ficamos em contato com a língua inglesa. Como conseqüência, nos acostumamos a usar várias palavras que não são traduzidas, mas que, pelo seu uso constante, acabam sendo compreendidas até por quem não fala inglês. Palavras e frases inglesas estão nas nossas ruas, casas, escritórios, escolas, academias etc, o que alguns vêem como uma ameaça à soberania nacional. 
É evidente a importância do empréstimo como mecanismo de ampliação do léxico, daí a razão de muitos lingüistas entenderem os empréstimos como uma forma de neologia. Observem-se, a seguir, algumas classificações de neologia propostas por autores que se ocupam do Léxico, as quais incluem o empréstimo como um processo de criação vocabular.

A constatação dos anglicismos pede uma reflexão sobre a grande influência dos Estados Unidos da América sobre nosso continente. Impregnados da cabeça aos pés pela indústria cultural, a América Latina apresenta diversos reflexos do processo de invasão cultural norte-americana, pela qual estamos passando há mais de meio século.

Em certas condições, uma língua pode tomar grande número de palavras por empréstimo de outra, cultural ou politicamente dominante. Foi o que aconteceu com o inglês na ldade Média, que se viu penetrado de termos franceses (beef, chance, arrive, pay, lesson e milhares de outros). No entanto, a estrutura gramatical não mudou e o vocabulário básico (artigos, conjunções, preposições, pronomes, auxiliares, além da imensa maioria dos termos de uso cotidiano) é predominantemente original - o inglês ainda é muito nitidamente uma língua germânica, e não uma mistura com o francês.

Segundo Alves (1990), o acervo do léxico português tem-se enriquecido, através dos séculos, por meio de dois procedimentos: processos vernáculos (derivação, composição, truncação, transferência semântica) e empréstimos de outros sistemas lingüísticos. Os empréstimos (do árabe, do provençal, do italiano, do espanhol, do francês, do inglês...) foram, assim, incorporando-se ao patrimônio lexical do português. 
Ainda segundo Alves (1990), na língua comum, podemos verificar que o empréstimo reveste-se de três modalidades. Apresenta-se, inicialmente, sob forma de estrangeirismo, ou seja, é utilizado para imprimir um certo exotismo, um pouco de cor local ao discurso do falante. A fase neológica corresponde à implantação da unidade lexical, em que esta se torna freqüente e, muitas vezes, sofre um processo de adaptação, seja ortográfica, fonológica ou de caráter morfológico - língua receptora. $\mathrm{O}$ empréstimo propriamente dito constitui a unidade lexical já difundida e incorporada ao acervo lexical do idioma.

A incorporação de termos estrangeiros é inerente às línguas vivas, e está relacionada a aspectos culturais e mesmo geopolíticos. Alves (1990) afirma que o estrangeirismo passa por algumas etapas até integrar-se à língua receptora. Primeiramente, o elemento estrangeiro é sentido como externo à língua vernácula, não fazendo parte do seu acervo lexical. Em seguida, o estrangeirismo é empregado juntamente com uma forma vernácula, sobretudo em textos escritos, com o objetivo de facilitar a compreensão do leitor. Essa forma traduzida pode tornar-se uma forma concorrente do estrangeirismo, alternando-se com ele, ou seja, num mesmo texto, para que não fique repetitivo, emprega-se ora o estrangeirismo ora o equivalente vernáculo.

Para a autora, a etapa propriamente neológica do estrangeirismo ocorre quando há integração à língua receptora. Essa integração pode manifestar-se por meio de adaptação gráfica, morfológica ou semântica. Exemplos de adaptação gráfica seriam shampoo/xampu e tournée/turnê. Já as adaptações morfológicas ocorrem quando os empréstimos começam a formar derivados ou compostos, como por exemplo: estressar, estressante, estressado (derivação: todos esses substantivos advêm da base stress à qual se unem afixos vernáculos), marketing 
verde (composição). As adaptações semânticas dizem respeito à mudança de significado que pode sofrer o empréstimo, passando a ter um emprego polissêmico, dependendo do contexto.

Para esses casos, a autora oferece alguns exemplos, entre eles o item léxico skin-head que significa originalmente "integrante de uma associação de jovens que usam as cabeças raspadas" e passa a significar simplesmente "sambista quem tem cabeça raspada". Observe-se no texto: "Sem nunca desligar seu radar detector de pesos-pesados, Pina - a skin head do samba - caiu na gandaia." (Folha de S. Paulo, 1989 apud Alves, 1990, p. 78). A autora ainda cita o decalque como forma de integração do empréstimo, ou seja, "a versão literal do item léxico estrangeiro para a língua receptora." (Alves, 1990, p. 79) Exemplos seriam: weekend/fim de semana, supermarket/supermercado.

A língua hoje, como sempre, dá muito pouca atenção a seus sistematizadores. Vive, funciona e evolui à sua maneira, como todas as outras instituições sociais. Não falamos nem escrevemos hoje como em 1950, como não dançamos mais o twist, nem usamos luvas e chapéus para sair às ruas.

Nunca é demais lembrar que toda língua viva varia e muda. E essa dinâmica revela muito bem a história dos empréstimos em qualquer língua. Eles chegam e, antes de se instalar, são empregados com sua forma original, causando estranheza. À medida que esse empréstimo vai-se incorporando por meio de decalques, traduções ou adaptações ortográficas, os indivíduos passam a tratá-los como itens léxicos constitutivos da língua de chegada, esquecendo-se, portanto, da sua origem.

O que constitui uma língua não é apenas o seu léxico, mas fundamentalmente a sua gramática, isto é, seus sons, seus padrões silábicos, sua morfologia, sua sintaxe. E no tocante à gramática, a língua portuguesa está absolutamente intocada. 
Assim, é certo que, na fase de implantação do conceito e de seu respectivo termo, empréstimos de outras línguas são introduzidos no português. Correspondem, portanto, a uma necessidade do desenvolvimento econômico e tecnológico. Todavia, tendem a ser, pouco a pouco, traduzidos ou substituídos por termos de caráter vernáculo pelos próprios usuários, os profissionais que trabalham com as línguas de especialidade. Nem sempre, é verdade, os termos criados em português são condizentes com as regras de formação da língua portuguesa. Este problema, porém, somente poderá ser resolvido com a implantação de uma política adequada de planejamento lingüístico no Brasil, que contemple, por um lado, a formação de terminólogos e, também, a criação de comissões de terminologia destinadas a assessorar os profissionais que trabalham nas variadas línguas de especialidade.

É claro que a maioria dos falantes, tanto de idioma português quanto espanhol, não vêm no uso dos anglicismos um problema, como postulam alguns legisladores e puristas. Talvez os falantes acreditem que utilizar anglicismos em determinadas situações de linguagem não torna impura a língua vernácula.

Parte das contribuições sociolingüísticas ao estudo do multilingüismo social é estabelecer a aberta diferenciação entre o anglicismo léxico e o empréstimo integrado. É preciso estabelecer as estratégias e instrumentos indispensáveis para superar as imitações e deficiências do passado, com a utilização equivocada do termo empréstimo para denominar tanto o processo de transferência léxica como o resultado do elemento transferido.

A princípio, a análise sociolingüística do comportamento bilíngüe depende tanto dos modelos pragmáticos de atuação comunicativa, como de uma teoria interdisciplinar. O indivíduo deve ser considerado como membro da comunidade de 
seu idioma, que se caracteriza por um conhecimento compartilhado das restrições comunicativas e das normas de comportamento social. É preciso observar, por outro lado, que multilingüismo social é um conceito integrador, relativo e neutro, que não determina o grau de competência nem a freqüência de uso variável, como tampouco o âmbito das distintas línguas particulares, nem a diferenciação social e funcional entre elas.

A teoria de identidade social proporciona uma análise das estratégias de troca social, com a finalidade de chegar a uma diferenciação psicolingüística positiva, e determina a dinâmica de conservação ou substituição lingüística. A comparação social com um grupo étnico externo sobre certos valores (poder, recursos econômicos, atributos intelectuais etc.) tem como resultado uma identidade positiva ou negativa para os membros do grupo, que adotaram em último caso uma ou várias estratégias de mobilidade social, criatividade social ou de competição social, com a finalidade de superar as limitações inerentes. Quando se aceitam os valores do grupo dominante, os membros dos grupos subordinados desenvolvem uma identidade social negativa. Uma estratégia importante para conseguir a mobilização social ascendente consiste em uma convergência até as características lingüísticas do grupo externo.

Em um mundo onde quem manda é o poder econômico, a velocidade tecnológica parece não deixar tempo para a reflexão. Procurando direcionar o olhar para o aspecto humano da língua, George Steiner nos oferece uma visão dos benefícios dos anglicismos na Língua Espanhola, considerando as línguas como elementos importantíssimos para a criatividade humana. Steiner (2001, p. 47) afirma que 
Os benefícios dos anglicismos são evidentes, pois facilitam enormemente o comércio internacional, o progresso junto com a ciência, o armazenamento da informação, a organização do entretenimento e do esporte em escala global e o turismo. Mas também há desvantagens porque cada vez que uma língua morre (e calcula-se que podem morrer 5.000 das 20.000 que existiam até há pouco tempo) há uma diminuição irreparável na criatividade humana, porque não há língua sem importância." E por outro lado estão os efeitos devastadores da utilização da identidade lingüística como veículo de conflitos étnicos. Nos conflitos étnicos os idiomas têm um papel decisivo. Para isto, só a educação, com o multilingüismo adquirido desde a infância oferece alguma possibilidade de solução. (STEINER, 2001, p. 47)

É através da diversidade que as várias línguas nos oferecem maneiras de compreender o mundo. Ao mesmo tempo nos oferece uma solução para manter a integridade das mesmas, que é o multilingüismo, onde não existe uma competitividade pelo prestígio e sim uma mútua e respeitosa compreensão.

A própria formação do português brasileiro é multilingüista, uma vez que o idioma falado hoje no Brasil é muito diferente daquele trazido pelos portugueses e falado no início da colonização, ainda no século XVI.

Acredita-se que o cenário de multilingüismo ocorrido no período de formação do Brasil devido ao convívio entre portugueses, índios e africanos teria sido favorável ao surgimento de um língua emergencial, resultante do contato entre falantes, não só de línguas diferentes, mas também de costumes e posições sociais diferentes. Esse cenário teria também favorecido a se eleger uma das línguas como a de prestígio, geralmente a do colonizador, como ocorre em situação de contato. No Brasil, elegeu-se a língua dos portugueses.

A situação de multilingüismo no Brasil não se deteve a um pequeno espaço de tempo. Ela se prolongou por três séculos (XVI a XIX), com a constante chegada 
de navios negreiros vindos da África, o que não permitiu que se constituísse uma língua crioula, já que a situação de multilingüismo se repetiu inúmeras vezes, impedindo que se fixasse uma determinada língua: mal se formava uma comunidade lingüística, nelas eram introduzidos falantes de línguas diferentes recém chegados da África, que teriam que passar pelo processo anterior, simplificação/redução da língua alvo, que agora não era mais o português dos europeus, mas a variedade já surgida e estabelecida naquele local. Assim, sempre que eram introduzidos novos indivíduos trazidos da África, surgia uma nova variedade, diferente da língua alvo, da língua nativa do falante e da língua que já se insurgia como socializadora, o que promovia a convivência de estágios diversos da língua. Em tal situação, não ocorre o estabelecimento do pidgin/crioulo típico, mas uma variedade da língua alvo que não esconde os múltiplos processos de aquisição por que passou.

Para explicar esse aspecto peculiar na formação do português do Brasil, surge o conceito de transmissão lingüística irregular que "constitui um contínuo de níveis diferenciados de socialização/nativização de uma língua segunda, adquirida massivamente, de forma mais ou menos imperfeita, em contextos sócio-históricos especificos" (Lucchesi, 2000, p. 104).

Considerando a história demográfica brasileira, não há dúvidas de que o quadro atual, em que o português figura como língua hegemônica, vai se paulatinamente estabelecendo ao longo dos anos da colonização e torna-se irreversível em meados do século XIX, a partir de quando, ao menos oficialmente, se encerra a entrada de contingentes de escravos negro-africanos no Brasil. Toma-se, pois, como marco divisor entre duas fases claramente distintas da história lingüística brasileira o ano de 1850, data oficial da extinção do tráfico negreiro no Brasil. 
A percepção da necessidade de uma multiplicidade lingüística nasce do conceito, explicitado por Steiner, de que não existe língua pequena nem melhor, apenas diferente, com todas as complexidades e características próprias que os seus falantes imprimam, desde o surgimento de cada uma delas até a sua atual estruturação.

Hoje, a língua portuguesa apresenta várias palavras que já foram incorporadas ao vocabulário e ao cotidiano do brasileiro (hot dog, bar, delivery, mouse, link, shopping, show). O uso dos anglicismos pode apresentar duas vertentes - comprometer a eficácia da comunicação, funcionando como um ruído entre o destinador e o destinatário, ou pode facilitar essa comunicação ao se utilizar de vocábulos mais simples e diretos que os seus correspondentes na língua portuguesa.

\subsection{O ANGLISCISMO SOB VÁRIOS ENFOQUES}

Em situações específicas de uso e por falantes também específicos, os estrangeirismos podem ser compreendidos pelos falantes de outros idiomas locais, sem necessariamente sofrerem adaptação ao idioma vernáculo. A compreensão ou não de uma palavra em um contexto de uso não implica a necessidade do conhecimento prévio de sua origem. 


\subsubsection{ENFOQUES ESTILÍSTICOS}

Uma primeira solução consistia na criação de um nível lingüístico posterior aos mencionados: o nível fraseológico. Assim, Lagueux (1988, p. 108) considera que "o traçado fraseológico consiste em traduzir literalmente sem levar em conta o universo conceitual da língua receptora". Darbelnet (1976, p. 110) já havia chegado há muito tempo a uma caracterização similar, ao definir uma categoria denominada como anglicismo de imagem: "chama-se assim porque representa o empréstimo de uma imagem e não um sentido ou uma estrutura." As comparações implícitas que introduzem assim na língua foram pensadas em inglês.

Neste mesmo trabalho, Darbelnet foi ainda mais longe, oferecendo uma vaga, mas sugestiva caracterização do anglicismo cultural: esta categoria se aplicava em princípio a uma adoção de toda a característica de uma cultura estrangeira, porém vizinha, como os métodos educativos, a forma de vestir etc. Mas, em um sentido mais restrito o anglicismo cultural se limitava a aspectos discursivos ou pragmáticos, como as rotinas e regras de comunicação.

\subsubsection{ENFOQUES FUNCIONALISTAS NO MARCO DA LINGÜÍSTICA CONTRASTIVA}

No âmbito do funcionalismo aplicado à lingüística contrastiva e à tradução, alguns estudiosos chegaram a esboçar uma categoria similar ao anglicismo cultural de Darbelnet, a partir da consideração de que certas rotinas e regras de comunicação não podiam ser traduzidas literalmente de um idioma para outro. Não 
se tratava de uma questão gramatical, mas normativa, idiomática e de freqüência, que poria um manifesto à natureza da língua como entidade social e cultural.

Ao examinar os limites da tradução, Coseriu (1978, p. 106-109) destaca que "não basta saber o que poderia dizer-se em uma língua; há que saber também o que se diz normalmente e em determinadas situações". Em conseqüência, não se deve traduzir a norma de uma língua pelo sistema de outra, pois nesse caso se obterão resultados ininteligíveis.

\subsubsection{O ENFOQUE TRADUTOLÓGICO: FALTA DE EQUIVALÊNCIAS PERFEITAS E EXCESSIVA FREQÜÊNCIA DE MODELOS ESTRANGEIROS}

A ênfase de Coseriu (1978) sobre o que se "diz normalmente“, "o normal" e "o mais freqüente" em uma língua como requisito para uma boa tradução nos leva a uma terceira e última aproximação teórica a noção de interferência pragmática, o empréstimo freqüente como variedade periférica ou marginal do empréstimo:

a) Lorenzo (1987, p.74) define o anglicismo freqüente como "o uso sem moderação de certas palavras e expressões que, se não são anglicismos em si, ao excluir outras opções que oferece a língua espanhola, são, por sua insistência, estranhos e monótonos".

Em um trabalho posterior, Lorenzo (1996, p. 91-92) aplica esta categoria de anglicismo freqüente a uma sintaxe e às fórmulas de conversação.

b) No âmbito da tradutologia, Vázquez-Ayora (1977, p.102-140) dedica um amplo capítulo aos anglicismos freqüentes, definidos desta maneira tão prolixa:

Quando em vez de selecionar a mais apropriada das 'correspondências' que oferece o espanhol nos contentamos 
simplesmente em copiar a forma mais parecida ou, inclusive, a mesma do inglês, e quando dessa forma há exagero na freqüência da língua anglo-saxônica, se tem criado uma anomalia que se difunde através de toda uma versão, tornando difícil a assimilação e delatando uma maneira estrangeirizante que não se amolda ao gênio de nossa língua. (...) Tem-se produzido um anglicismo de freqüência. Como seu nome indica, é causado pela 'freqüência' insólita com que aparece algum "termo" ou "expressão" sem que esse "termo" ou "expressão" seja necessariamente um anglicismo em si. Pode não ser termo estrangeiro, mas sua repetição no uso não é própria, e ele se distingue das outras classes de anglicismo que temos conhecido antes (...).

\subsubsection{O ENFOQUE PROPRIAMENTE PRAGMÁTICO: A COMPETÊNCIA COMUNICATIVA}

Apesar dessas interessantes aproximações à essência da interferência pragmática, as primeiras caracterizações globais desta modalidade de interferência não chegam até 1970 e correm paralelas ao desenvolvimento de disciplinas como a Etnometodologia, Etnografia da Comunicação, Análise Conversacional e a própria Pragmática em sentido estrito.

O primeiro autor que aborda explicitamente a possibilidade de empréstimos que afetem o nível pragmático é o lingüista australiano de origem alemã Clyne (1972) e (1977), em seus trabalhos sobre a fala dos imigrantes alemães na Austrália.

Em seu primeiro trabalho, Clyne (1972:98-110) estuda o "contato da linguagem com o discurso". Este autor estabelece as seguintes categorias de "empréstimos discursivos":

1. Marcadores discursivos. 
2. Certos tipos de falas usuais no chamado discurso repetido ou ritualizado.

3.Entre línguas tipológica e culturalmente similares existem notáveis diferenças nas regras de fala ou rotinas discursivas..

Em outro trabalho, Clyne (1977) fala de transferência pragmática, uma vez que formula a existência de um nível pragmático no sistema lingüístico (em pé de igualdade com os níveis tradicionais: léxico, fônico, semântico etc.): "Estudos anteriores de bilingüismo mostram a transferência, em vários níveis - fonético, fonêmica, prosódico, lexicais, semânticas, sintáticas, grafêmico. No entanto, transferência também ocorre regularmente no nível pragmático".

Neste trabalho, Clyne se baseia em diversos princípios teóricos da Pragmática e da Etnometodologia para elaborar seu marco de estudo das transferências pragmáticas.

Em primeiro lugar, parte do conceito básico de competência comunicativa, no sentido clássico estabelecido por Dell Hymes (1974), como superação da mera competência sintática chomskiana. Portanto, se trata de um nível superior ao âmbito oracional e às regras sintáticas, uma vez que incluem aspectos não estritamente lingüísticos, como os de tipo cultural.

Clyne observa que as diferenças que implicam a competência comunicativa em diversos idiomas podem conduzir a um "erro comunicativo" quando a intenção não é compreendida corretamente ou inclui um "conflito comunicativo" quando esta má compreensão deriva em algum tipo de choque ou conflito.

Em um trabalho recente, Payrató (1992, p.148) formula uma interpretação da interferência pragmática com muitos apontamentos de Clyne, mas com certas concepções estilísticas e afetivas do empréstimo: 
A interferência constitui um pequeno recurso comunicativo mais utilizado pelos indivíduos falantes com numerosos significados adicionais, tanto pragmáticas ou expressivas (irônicas, humorísticas) como sociais (marcas de variedade social, de neutralização de possíveis conflitos, etc.).

No terreno da tradução, Acosta (1987, p. 54-55) adverte que a falta de equivalências entre dois idiomas pode dar-se também em nível pragmático. $\mathrm{O}$ lingüista espanhol parte da mesma base que Coseriu e Clyne: em línguas diferentes, as regras de interação comunicativa não são equivalentes, no sentido de que não se pode traduzir literalmente. Para Acosta, o nível pragmático "supera os níveis teóricos da competência para chegar à performance (...) levando em conta na análise da língua, elementos como a situação e o contexto em que se produz o fato."

\subsubsection{O ENFOQUE INTERCULTURAL}

Finalmente, Wierzbicka (1991) proporciona um enfoque complementar da interferência pragmática. A pesquisadora polonesa parte da crítica aos planejamentos etnocentristas da tradição lingüística e etnometodológica anglosaxônica e oferece um amplo corpus de atos de fala de diversas línguas no que se põe uma curiosa comunidade cultural frente à especificidade anglo-saxônica.

Em concreto, Wierzbicka (1991) deduz deste amplo material uma série de traços culturais comuns às línguas romanas e eslavas, e às vezes opostas à cultura anglo-saxônica: afetividade, espontaneidade, sinceridade, dogmatismo etc. Por sua vez, estes traços culturais têm seu reflexo em uma série de mecanismos pragmáticos, atos de fala e recursos morfossintáticos: assim, por exemplo, a cultura anglo-saxônica - e, em conseqüência, a língua inglesa- mostra uma marcada 
tendência a evitar o imperativo em pedidos, pelo qual se têm desenvolvido numerosos mecanismos para realizar pedidos utilizando a forma interrogativa; em troca, as línguas eslavas e romanas, mais diretas e menos atenuadoras, utilizam com bastante freqüência o imperativo em pedidos.

As condições culturais na teoria e na prática da tradução são antigas. Santoyo (1996, p. 38) cita Mounin (1976, p. 50), segundo o qual não se deve contentar apenas em ser um bom lingüista, mas se deve ser também um etnógrafo excelente. Um dos pioneiros no estudo da interferência pragmática desde a perspectiva lingüística, Clyne tinha muito presente as considerações culturais. Desta forma, este autor insiste em que, línguas de culturas próximas, quando comparadas, apresentam claras divergências no comportamento discursivo. Atualmente, quando a internacionalização da cultura é muito mais acentuada que anos atrás, os trabalhos sobre interferência discursiva e cultural seguem insistindo em profundas diferenças de hábitos comunicativos que separam as próprias nações ocidentais, como assinalam Inigo e Westall (1998, p. 93).

Deste enfoque intercultural surge, de maneira clara e diretamente relacionada com os objetivos deste trabalho, a hegemonia da cultura anglo-saxônica especialmente a norte-americana - no mundo atual. Esta hegemonia não apenas se manifesta no empréstimo, mas terá interferência gramatical, visto que se estende muito além: o inglês norte-americano é o espelho através do qual se vêem as demais culturas mundiais da chamada aldeia global.

Em seu estudo sobre os anglicismos, Pergnier (1989, p.102) vê este fenômeno da seguinte maneira: não apenas se converteu em uma "língua de interferência", mas em uma "língua de referência", o que proporciona constantemente um padrão dos mecanismos lingüísticos de outras línguas. Segundo 
o lingüista francês, esta situação, até há pouco limitada às zonas de empréstimo íntimo e bilingüismo, é responsável por interferência em todos os níveis lingüísticos, e começa a se dar nas línguas mais expostas à influência americana, como o espanhol e o português. E tudo porque a grande referência mental e situacional é norte-americana. Tem-se a mentalidade de que tudo é mais tecnológico e avançado nessa parte do continente.

Riquelme (1998, p.51-63) propõe enfatizar a diferença entre o anglicismo lingüístico e o cultural, mantendo o termo anglicismo para o tipo lingüístico (geralmente léxico) e habilitando o antigo termo anglicismo para designar "essa influência da cultura anglo-saxônica nas formas de vida, gestos, atitudes e modas"; isto é, utilizando anglicismo com o valor que outros estudiosos atribuem ao termo anglicismo cultural. Neste sentido, o fenômeno do anglicismo cultural diferente do lingüístico, mas produto de uma mesma influência que afeta a todas as parcelas do saber e da atividade humana já foi formulado e analisado por Emilio Lorenzo em diversos trabalhos [Lorenzo (1980, p.109-110), (1987, p.71) e (1995, p.166)] desde seu primeiro artigo de 1955: o acadêmico espanhol menciona exemplos como o assobio de admiração às mulheres bonitas, os colunistas da imprensa, a árvore de natal, as unidades de medida não decimais, aspectos da vida da universidade (os campus, créditos, pós-graduação etc.).

Conseqüentemente, o anglicismo cultural está estreitamente ligado ao anglicismo pragmático quando um conceito restritivo do tipo verbal é aplicado, mas no sentido amplo ele inclui todos os elementos da cultura intelectual, material, as relações humanas e a comunicação. Como mostra de uma concepção etnológica do anglicismo cultural que pode integrar em sua descrição de fenômenos lingüísticos, podemos citar a proposta de Inigo e Westall (1998, p.93), que, ecoando uma longa 
tradição etnológica também presente nos próprios trabalhos sobre tradução, classificam estes anglicismos culturais em propriamente culturais, ideológicos, geográficos e lingüísticos (e neste último grupo cabem, precisamente, alguns anglicismos pragmáticos como as fórmulas de saudação, juramento ou blasfêmia)

Voltando ao enfoque intercultural propriamente dito, observamos que este duplo papel da língua e cultura anglo-saxônica, como exportadora e língua de interferência por um lado, e como mediadora e ponto de referência cultural por outro, se vê com bastante claridade no mundo do cinema. O espanhol já sofre um processo de transculturação que implica uma argumentação semelhante à de Pergnier sobre o francês canadense e o europeu:

Os filmes de cinema e televisão são produzidos, em sua maioria, nos Estados Unidos: seus costumes, suas festas, servem de modelo, de referência que se tornam corriqueiras em outros países. Algumas culturas se sentem acuadas pelas novas referências que entram nos domicílios diária e constantemente através de filmes da grande indústria norte-americana e seu estilo de vida norte-americano. Um exercício de reflexão pode consistir em assistir criticamente a um filme norteamericano (de estudantes universitários, por exemplo): observar seus hábitos, suas reações, suas comidas, suas atitudes, suas inquietações, seus valores etc. analisarmos e depois compararmos com a vida de nossa cidade ou em nossa volta, conosco, nossos jovens estudantes. Se olharmos para uns trinta ou quarenta anos atrás e analisarmos um filme de nosso cinema, compreenderemos que alguns aspectos estão se igualando à vida americana e como a identidade cultural vai se tornando obsoleta.

Também Inigo e Westall (1998, p. 101) manifestam o poder do cinema como mecanismo exportador de hábitos lingüísticos e culturais norte-americanos: 
No entanto, estamos constantemente alertando para a imposição cultural, que é importada por meio do cinema: a sua capacidade de atingir todos os setores da sociedade, para tornar banais, elementos que até pouco tempo atrás eram desconhecidos fora da cultura.

Assim, o cinema é a ponta da lança transcultural e da incorporação aldeia global norte-americanizada. Como afirma McCarthy (apud Jiménez, 1997, p. 311):

O conhecimento das diferenças interculturais entre polissistemas (línguas naturais em sentido amplo) deve servir para evitar - tanto na tradução como na aprendizagem de segundas línguas - o fracasso pragmalingüístico e sóciopragmático. E estes dois conceitos, retirados de Thomas (1983, p.99), enlaçam diretamente as noções mais simples de "erro comunicativo" e "conflito comunicativo" nos diversos trabalhos pioneiros de Clyne. Poderia supor-se, inclusive, que Thomas reelabora os conceitos de Clyne levando em conta os estudos posteriores sobre a competência comunicativa (em especial, a compartimentalização da competência comunicativa que propõem Canale e Swain (1980) e Canale (1983) em competência lingüística, sociolingüística, textual/discursiva e pragmática):

a) Para Thomas, o fracasso pragmalingüístico se dá quando o receptor não percebe a força pragmática que o emissor quis transmitir.

b) O fracasso sócio-pragmático surge do desconhecimento do que se considera comportamento sociolingüístico apropriado na segunda língua.

Concluindo, a breve panorâmica oferecida por Valero et all. (1997) do nível ou aspecto pragmático-discursivo na análise da tradução e da aprendizagem de segundas línguas mostra as necessárias semelhanças e analogias entre as diferentes abordagens a partir da simples descoberta do problema na Estilística e Funcionalismo, até considerações inteiramente interculturais, através de considerações pragmáticas, com base no conceito-chave de competência 
comunicativa. Portanto, temos a intenção de aproveitar os apontamentos e sugestões de todas essas áreas para desenvolver uma visão compreensiva do anglicismo pragmático de uma forma muito especial.

Em resumo, podemos dizer que a interferência pragmática e cultural em filmes e seriados americanos não é muito pronunciada no aspecto quantitativo, mas, em termos de qualidade, é possível documentar casos de influência angloamericana em quase todas as áreas do discurso que atualmente estão sob consideração da pragmática: discursos marcados, regras de fala e rotinas discursivas relativas a diferentes momentos da interação dialógica (início e fórmulas apelativas ou fáticas, espelhos, fórmulas de acordo, a mudança de turno e encerramento discursivo). Fórmulas de fixação pragmática vinculadas a vários rituais da vida social (tratamento, cortesia e pedido, agradecimento, parabéns e despedida). Procedimentos de mudança do enunciado (advérbios, afirmação, negação e probabilidade). Ênfase, atenuação e exclamações.

Em contraste, a penetração e difusão destes elementos pragmáticos de signo anglo-americano nos próprios hábitos lingüísticos dos hispano-americanos é algo a que não se pode responder com comentários impressionistas e previsões apocalípticas, mas deve ser determinado através de um estudo de diversos modos de falar desde o mais permeável à influência americana ao mais remoto a partir dele.

Uma das variedades de tradução mais propensas à presença de empréstimos pragmáticos é a dublagem de filmes e seriados estrangeiros, como eles operam em uma variedade de linguagem que imita o diálogo e a língua falada espontânea (foco de interferência em situações pragmáticas sobre bilingüismo) e, muitas vezes, adota os valores culturais do modelo. Isto é particularmente visível quando o modelo é 
também - como na fala dos imigrantes bilíngües - a poderosa cultura material norteamericana, conhecida e imitada por todo o mundo.

Agost (1997, p. 817) e (1999, p.9) também reivindica a importância da dublagem como uma forma de tradução básica da sociedade atual, ponderando seu valor intercultural e lamentando a pouca atenção que tem recebido até o momento (até ao ponto de duvidar que a dublagem é realmente uma forma de tradução). E como acontece na própria lingüística - é curioso encontrar em autores clássicos maior perspicácia e visão do que existe hoje. A este respeito, Agost recorda que um dos autores clássicos da teoria e prática da tradução, Nida (1964, p.177), levava em conta a importância da dublagem na vida moderna, claramente considerada, como uma forma a mais de tradução, e criticou sua marginalização nos estudos tradutológicos.

A tradução foi sempre considerada, desde a Antiguidade Clássica, como uma das mais poderosas e sutis maneiras de entrada das influências idiomáticas e culturais. Em particular, como a única via possível de entrada para empréstimos nãolexicais (geralmente sob a forma de termos ou substituição morfológica) em situações de empréstimos culturais entre as grandes línguas européias. Os galicismos semânticos e sintáticos do século passado devem a sua entrada às desastrosas traduções contra as reações puristas, jornalistas e acadêmicos. E os anglicismos semânticos, sintáticos e morfológicos deste século devem também a sua entrada a traduções deficientes, mas as dimensões e as áreas consideradas se multiplicam, pois:

- O volume das traduções é infinitamente maior do que o século passado. 
- Não são apenas os textos traduzidos escritos, mas também os textos orais (no todo ou em parte derivados de um modelo de carta).

- A tradução de textos orais que procuram imitar a língua diária, como nos diálogos cinematográficos, abrem as portas para a entrada de termos relativos ao elemento discursivo que regem intercâmbios comunicativos ordinários: e é aqui onde se produz a interferência pragmática em uma situação teórica de empréstimo cultural diferenciado e sem bilingüismo.

No espanhol atual, a tradução é um dos mais poderosos meios de entrada de empréstimos e termos. Entre as formas de tradução, investigadores do anglicismo no espanhol têm desenvolvido um papel proeminente - destacando a dublagem na televisão e no cinema. Mas o que é estranho - perigosamente estranho - é que, embora os autores do período 1960 a 1980 tivessem posto em evidência a importância da dublagem como meio de entrada, os dubladores continuam sendo o "primo pobre" dos estudos de tradução.

Os malefícios do inglês estão agora, se é que é possível, ainda maiores. Um novo elemento foi adicionado às tradicionais rotas de invasão: televisão. Como esperado, na era "anglicada" da televisão foram os elementos léxicos que levaram à condenação de mais conservadores e em troca vieram, sem comentários, verdadeiras monstruosidades que revelaram o desconhecimento dos tradutores.

\subsection{OS CAMINHOS DA INVASÃO}

O uso de anglicismos nos meios de comunicação de países latinos, como por exemplo o jornal, tem aumentado notadamente neste novo milênio, aumentando o 
léxico e ampliando as possibilidades de uma melhor interação lingüística, principalmente tecnológica. No entanto, a língua oficial está sendo soterrada por sinônimos que são substituídos, visto o prestígio que adquiriu essa outra língua na mídia que os promove.

Acredita-se que o imperialismo lingüístico do inglês não é a força real do inglês em si, mas da expansão econômica, cultural e tecnológica dos EUA. A língua é secundária e vem com o resto. Os homens preferem falar a língua que lhes permite se movimentar no planeta, portanto, se os Estados Unidos é potência e dominante na área de informática, é natural que as palavras referentes ao assunto sejam conservadas em sua forma original.

\subsubsection{MEIOS DE COMUNICAÇÃO}

Os meios de comunicação em massa continuam sendo uma das principais vias por onde os anglicismos se introduzem em outros idiomas. Muitas notícias publicadas em revistas, e mais recentemente nos sites da internet, têm origem em países de língua inglesa, que enviam suas informações à imprensa do mundo todo. A tradução desses textos é feita rapidamente, levando, muitas vezes, à adoção de palavras e significados do inglês, contribuindo ainda mais para a disseminação dos estrangeirismos.

Este problema de tradução afeta a todos os meios de comunicação que caracterizam uma sociedade moderna. Os livros, que no passado constituíam um veículo privilegiado para a difusão de idéias e de novas palavras, hoje possuem menor importância para o fenômeno do anglicismo. Mesmo que muitos dos livros consumidos na América Latina sejam traduções de obras escritas originalmente em 
inglês, sua influência no idioma é pouco relevante, seja por não ter um público tão numeroso, como as revistas e a televisão, seja porque a língua literária usada em livros geralmente é percebida em um plano diferente da língua usada no cotidiano, ou seja, é considerada uma linguagem formal, sendo bastante raro que influencie diretamente na fala diária das pessoas.

Em compensação, os meios de comunicação em massa que contribuem de maneira extremamente significativa para a difusão de anglicismos são a televisão e o cinema.

Uma das causas principais deste feito é o papel que desempenham as agências de imprensa internacionais. A maioria de origem anglo-americana, através de matérias redigidas em inglês e traduzidas às pressas, difundem termos anglicistas em suas revistas. Fora isso, existem outras publicações que, mesmo estando fora da esfera internacional, preferem o uso de anglicismos em suas páginas, talvez como uma forma de equiparação às revistas internacionais.

No que se refere à televisão, desde os anos setenta até hoje, é o meio de comunicação de maior influência em todo o mundo. Como resultado do crescimento do público que assiste à TV, os programas e os filmes que são transmitidos pelos canais latinos têm uma repercussão notável, tanto na língua como nas atitudes sociais dos cidadãos.

Muitos dos quadros dos programas de televisão exibidos na América latina são cópias ou exportações de quadros exibidos em canais de TV norte-americanos. É por isso que, através deles, mais que léxicos e culturas inglesas se propagam. Também se espalham atitudes, gostos, modos de vida e preferência típicas da sociedade estadunidense. 
As séries, os documentários, os filmes realizados nos Estados Unidos e dublados para o espanhol e para o português são vistos diariamente por milhões de telespectadores, inclusive crianças que estão ainda adquirindo a capacidade de fala, influenciando de maneira notória na introdução de expressões lingüísticas, principalmente sintáticas, pela má qualidade de algumas traduções e dublagens.

Algumas redes de TV, principalmente as digitais, transmitem filmes em sua versão original, com legendas, sendo que muitos telespectadores preferem esta versão à aquela dublada. $\mathrm{A}$ isso se soma o fato de que o número de espectadores assinantes destas TVs digitais ou possuidores de antenas parabólicas com recepção de canais norte-americanos, britânicos e de outros países de língua inglesa cresce a cada dia. Por tudo isso, não é de se estranhar que muitos dos termos do mundo televisivo sejam anglicismos, como prime time, ratings, share, set, late nights, zapping, pay per view.

Por último, queremos destacar o meio de comunicação por excelência do fim dos anos noventa: a internet. A facilidade e o relativo baixo custo de seu uso, somados às possibilidades infinitas para estabelecer contatos com o exterior e buscar todo tipo de informações, têm levado, em poucos anos, ao sucesso da Internet em todo o mundo, principalmente entre jovens e no meio universitário e comercial. Como quase todas as tecnologias avançadas, a internet nasceu nos EUA, assim como toda a terminologia relacionada a ela (página Web, website, Usenet, telnet, intranet, newsgroups, chat, host,) tem sua origem no inglês. Afinal, este idioma se transformou também na língua mestra daqueles que estão conectados à rede e distribuem mensagens por todo o mundo. 


\subsubsection{TECNOLOGIAS}

O setor tecnológico é uma das áreas que mais se utilizam da introdução de novos termos que passam do uso especializado ao comum graças à rápida difusão dos meios de comunicação digital, como por exemplo, a internet. Neste âmbito verifica-se uma supremacia de anglicismos, representados por estrangeirismos como "e-learning", "e-assessment".

\subsubsection{O FATOR ECONÔMICO, INDUSTRIAL E COMERCIAL DOS ESTADOS UNIDOS E DO MUNDO ANGLO-SAXÃO}

O inglês tornou-se também franquia inquestionável e idioma do comércio, da indústria internacional e da economia. Se os Estados Unidos são o país que mais investem na pesquisa científica, é lógico que é também é um dos países principais no comércio internacional, porque exerce a liderança das vendas dos produtos que cria ou aperfeiçoa e, conseqüentemente, sua língua, neste caso o inglês, prevalecem acima das outras.

Também é importante recordar que as empresas multinacionais, geralmente norte-americanas, obrigam suas sucursais a manter um sistema administrativo e contábil em língua inglesa, para que seja facilmente interpretado por diretores das matrizes.

Ainda devemos considerar que tanto o Japão quanto as colônias britânicas na velha Ásia (Hong Kong, Formosa, etc.), que tanto protagonizaram no mundo dos negócios nos anos oitenta e início dos anos noventa, usaram o inglês nas relações comerciais entre elas e o restante do mundo. O mesmo pode ser dito dos países da 
União Européia, entre eles a Espanha, cujos industriais recorrem a esta língua quando assinam, com outras nações, contratos de importação, exportação e distribuição da mercadoria e, no geral, ao fazer qualquer tipo de transação econômica internacional.

Os Estados Unidos são também um dos países que mais desenvolvem pesquisas acadêmicas na ciência da economia e das finanças. Gomez de Enterría, especialista nesta matéria, declara que, no vocabulário da economia dos últimos trinta anos, a maioria grande dos termos de origem estrangeira são angloamericanos.

Este fato fez com que os profissionais de economia e finanças vissem a necessidade de aprender 0 inglês e de consultar às publicações de jornais especializados na área, que são em língua inglesa. Além disso, as notícias relacionadas ao mundo financeiro ocupam atualmente um lugar de destaque em todos os meios maciços de comunicação, como a televisão. Em conseqüência, muitos anglicismos da economia foram incorporados à língua comum, de modo que pudessem ser incluídos e compreendidos por um público muito amplo. Entre eles, estão leasing, marketing, ranking, overnight.

\subsubsection{PUBLICIDADE}

Como conseqüência direta do progresso econômico e da relevância do comércio e do mundo do consumo na sociedade atual, a publicidade se transformou em um dos fatores mais influentes, do ponto de vista sociolingüístico, nos falantes de qualquer país civilizado. Com o objetivo de impulsionar o receptor a atuar de acordo com a mensagem contida nos anúncios, os publicitários não hesitam em 
recorrer a qualquer tipo de estratégia que consiga impressionar ou, pelo menos, prender a atenção do consumidor. Um dos recursos psicolingüísticos mais usados e antigos é o que Medina (2007) chama de "o poder mágico da novidade" e a "admiração pelo que vem de fora". É a utilização de palavras ou expressões que causam estranheza, curiosidade, como é o caso dos estrangeirismos, para aumentar o poder de atração dos produtos.

Medina López (1994) diz que, para conseguir ampliar cotas do mercado internacional e, portanto, reduzir gastos com campanhas publicitárias, faz falta dispor de uma língua que se converta em mecanismos lingüísticos internacionais e facilmente identificáveis com um estilo de vida ou ideologia. Sem dúvida, o inglês cumpre, dia a dia, essa função aglutinadora de língua internacional comercial e publicitária.

Outra influência da natureza sociocultural da publicidade é a transculturação, ou seja, a popularização, especialmente com os anúncios da televisão, das atitudes, formas, costumes e gestos dos anglo-saxões e, principalmente, dos americanos. Trata-se do que Lorenzo (1987) denomina anglicismo cultural.

\subsubsection{POLÍTICAS INTERNACIONAIS E GLOBALIZAÇÃO}

A globalização é o empobrecimento da linguagem. Ouve-se muitas vezes que a globalização implica também a globalização lingüística, ou a ofensiva do inglês, cuja capacidade de penetração aumentou radicalmente nas últimas décadas, impulsionada particularmente pela internet. Grijelmo (1999) afirma que em apenas meio século, o inglês colocou em nossas bocas tantas palavras como o árabe em oito séculos. 
A invasão dos anglicismos assusta a muitos especialistas em muitos países, mas não a todos. Segundo Grijelmo (1999), o inglês começou a penetrar com força na língua espanhola em meados do século XX. Antes, o idioma havia sofrido uma ofensiva similar por parte do francês. Há um século, os neologismos de todas as línguas se construíam com palavras do latim e do grego. Também as influências tecnológicas eram provenientes de países que não falavam espanhol, como a Inglaterra, a França e a Alemanha.

Segundo Llosa (2000), um dos argumentos mais freqüentes contra a globalização é o desaparecimento das fronteiras nacionais e o estabelecimento de um mundo interconectado por mercados internacionais, o que infligirá um golpe nas culturas regionais e nacionais, nas tradições, costumes, mitologias e padrões de comportamento que determinam a identidade cultural de cada comunidade ou país.

A influência do inglês e da cultura anglo-saxão e a penetração de expressões e palavras inglesas não é somente um fenômeno que afeta o espanhol e o português e os países falantes destes idiomas, mas também afeta todas as línguas e culturas européias.

A expansão demográfica de um povo dentro ou fora de suas fronteiras geográficas ou políticas aumenta o lugar e a importância social de suas línguas. Um crescimento populacional maior de uma comunidade com relação a outra, condiciona a influência de suas línguas entre si, de suas perspectivas, mesmo que as situações sejam mais complexas.

No terreno da política, apesar do elevado número de tradutores e intérpretes que trabalham na seção de espanhol dos organismos internacionais, é necessário destacar o fato de que cada vez são mais os políticos, assessores e diplomatas que 
aprendem inglês para freqüentar as reuniões internacionais. Como indica Pratt (1980), não há o que discutir, hoje em dia o inglês é a língua da diplomacia.

No âmbito militar, a participação de países latinos na Organização das Nações Unidas - ONU tem propiciado que tropas latinas atuem em conflitos internacionais, convivendo com soldados de todo o mundo. Se se considerar o peso dos EUA e Grã-Bretanha neste tipo de intervenção militar, não é surpresa que a língua de comunicação empregada seja o inglês. Desta forma, o peso do inglês é também patente tanto no linguajar militar espanhol e português, como em seus falantes militares.

\subsubsection{PRESTÍGIO LINGÜÍSTICO}

Também acontece de o uso de anglicismos e a inclusão de termos em inglês no discurso de falantes de espanhol e português não estar associado diretamente a nenhum das situações acima mencionadas, mas estão ligados diretamente à pretensão dos habitantes em demonstrar que conhecem o idioma inglês.

Por motivos de índole sociolingüística, a língua estrangeira de prestígio para os latino americanos é o inglês. Pratt (1980) afirma que a presença, no espanhol, de muitos anglicismos que mantêm a escrita original, sem adaptações, se deve ao desejo de parecer moderno.

Este fenômeno de prestígio das línguas, de que se ocupam a psicolingüística e a sociologia da linguagem, explica que o prestígio da linguagem funciona como mediador do modernismo. É a janela para o mundo. Em conseqüência, quando os falantes de outros idiomas utilizam o inglês por esnobismo lingüístico, esta língua 
atua como símbolo de classe e status (percebe-se aqui um anglicismo), ou de modernidade.

A maioria dos lingüistas concorda em apontar os jovens, os editores, os economistas, os políticos e os intelectuais entre os falantes que mais recorrem ao uso do inglês. A respeito dos economistas, Herrera Soler (1990) corrobora esta opinião, quando inclui o esnobismo entre as causas principais da presença no espanhol de léxicos como baby boom, business center, delivery against payment e expressões que obedecem à atração e ao fascínio que exercem no mundo da economia e das finanças.

Tem-se que considerar que neste setor existem outros interesses que vão muito além do mero exibicionismo lingüístico. Como conseqüência do uso destes anglicismos como símbolo de prestígio, busca-se a obtenção de benefícios pessoais, como um bom cargo de trabalho ou uma ascensão profissional. Essa tendência está generalizada em todos os profissionais relacionados, de alguma forma, com o comércio e o mundo dos negócios, como é o caso dos vendedores de automóveis, que, quando se dirigem aos clientes de suas concessionárias, gostam de destacar o airbag, o reprise e o $A B S$ dos veículos que desejam vender.

Por outro lado, os redatores também costumam receber críticas por recorrer, com muita freqüência, ao inglês, por um esnobismo relacionado com o que Pratt (1980) denomina "función argótica". É dizer, na livre tradução, que se caracteriza por não se comprometer e resultar em uma vaga, imprecisa e ambígua declaração, típica da linguagem político-administrativa, reproduzida diariamente na imprensa.

Esta tendência parece caracterizar também outros profissionais. Navarro (1998, p. 1087), referindo-se aos médicos, comenta que: 
Todos nós temos algum amigo ou conhecido que, ao passar um período mais ou menos prolongado em um hospital estadunidense, nos fala, em sua volta, de seu paper que acaba de publicar em uma famosa revista internacional. Não ignora que está utilizando uma palavra inglesa, também não ignora qual é sua tradução correta. $O$ que ocorre é que, depois de uns meses ou anos no umbigo do mundo, tem que manter distância de seu ingênuo colega que publica na mesma famosa revista que ele, mas que não viajou ao exterior.

Ressalte-se que, mesmo que os anglicismos que correspondem a esta tendência surjam na fala de certos sujeitos influentes, ou de um registro determinado, difundem-se, por mimetismo, com muita rapidez, entre os falantes mais receptivos a este tipo de usos, desconhecedores, inclusive, do inglês. Também por esnobismo, ou por modas passageiras, muitos pais preferem batizar seus filhos com nomes estrangeiros, principalmente aqueles com origem no inglês.

\subsubsection{OS ADOLESCENTES}

Uma linguagem em que a influência da língua inglesa se faz sentir também, de forma clara, é a juvenil. Pela ação conjunta de muitos dos fatores (a publicidade, os meios de comunicação, sobretudo a televisão e a Internet, o entretenimento, os esportes e os jogos, o mundo do lazer e do espetáculo), é freqüente encontrar muitos anglicismos na fala dos jovens.

A esse respeito, Smith (1993) expõe que, com relação aos jovens, o vocabulário serve para marcar sua geração e abraçar seus usuários enquanto age excluindo outros. Esta linguagem (não apenas verbal, mas comportamental) não é 
pretensiosa, apenas nova e estranha, de modo equivalente aos estilos e extravagâncias e a música barulhenta.

O consumo de tudo o que é proveniente da América do Norte, tanto na música, quanto na televisão, nos hábitos alimentares, com as lanchonetes de comida rápida, os jogos (que, mesmo em sites brasileiros já são chamados apenas de games), a própria internet, campeã no uso estrito de palavras inglesas (download, site, link, email, hardware, spyware, backup, format etc.) e na criação de verbos derivados diretamente dessas palavras (backupear, formatar), além daquelas que têm expressão em português e que podem perfeitamente ser usadas, mas que são preteridas em favor da palavra em inglês (wireless $=$ sem fio, software $=$ programa).

Essa geração, criada em frente aos computadores, com celulares que já fazem parte de seus corpos, tão ligada que está à tecnologia, tem facilidade em aprender tudo aquilo por que se interessa e, estando voltadas e interessadas no idioma, cultura e modo de vida americanos, é isso que incorporará com a maior facilidade, deixando de conhecer suas próprias raízes (muitas vezes seu próprio idioma), mas conhecendo como ninguém todos os estrangeirismos.

\subsection{CONSIDERAÇÕES}

O esquema de níveis lingüísticos colocados por Carmen Valero et all. (1997) para avaliar fatores que afetam o fluxo de informações no processo de tradução. Estes autores partem, de fato, da consideração das línguas como polissistemas que reúnem vários sistemas lingüísticos e culturais que Valero et all. propõem limitar desta forma: léxico- semântico, pragmático e discursivo-pragmático. 
Essa curiosa classificação reflete o desejo de integrar a análise da tradução no amplo e abrangente quadro dos atuais estudos sobre linguagem, além da simples taxonomia morfossintática, e vem ao encontro das contribuições discutidas neste capítulo.

Neste nível, discute a tradução a partir da perspectiva da pragmática aplicada à análise do discurso, entendida como uma disciplina que lida com a análise das interações verbais.

Tanto o tradutor como um estudante de uma segunda língua não podem restringir-se a conhecer o código desta língua, uma vez que aparece em diferentes gramáticas formais, mas eles terão de adquirir uma competência pragmática e a capacidade de utilizar a língua de maneira eficaz para atingir uma finalidade específica e de compreender o contexto na língua.

$\mathrm{Na}$ seqüência das importantes contribuições em pragmática aplicada à análise do discurso, Valero et all. (1997) menciona os princípios de organização da conversa: o princípio da cooperação (teoria) e teoria da cortesia (Brown e Levinson).

A partir daqui, a necessidade de lançar as bases de uma pragmática contrastiva em que o apoio à tradução de um estudo mais aprofundado leva Valero et. all. (1997) a acercar-se dos enfoques interculturais: na verdade, princípios universais da cooperação e cortesia -, bem como os atos de fala concreta onde se manifestam - podem assumir valores diferentes em diferentes culturas. Neste sentido, os autores apontam para o estudo de Blum-Kulka, House e Casper (1989) como um instrumento fundamental da pragmática contrastiva, mas imediatamente centram as suas atenções sobre as contribuições de Wierzbicka, citando os seus trabalhos e petições em Língua e cultura anglo-saxônica e seu contraste com os procedimentos empregados nas línguas eslavas e culturas românicas. Neste 
aspecto, os autores destacam a curiosa semelhança pragmática e situação cultural das culturas e línguas eslavas e românicas diante do anglo-saxão, hoje predominante e convertido em um ponto de referência universal.

Naturalmente, a invasão do anglicismo nos idiomas latinos não é uma característica exclusivamente destes idiomas. O fenômeno se estende a grande parte das línguas do mundo. Este estudo explorou o português e o espanhol falados nas Américas porque são eles que recebem em maior intensidade a influência do inglês devido à proximidade geográfica e às estreitas relações econômicas entre os países latino americanos e os EUA.

O motivo da valorização de estrangeirismos, em especial de origem norteamericana, é o contato cotidiano com o inglês, devido à globalização, que gerou uma certa idéia de status, assim, parece mais fino falar pelas expressões que exigem uma 'forçadinha' no sotaque. Além do mais, demonstra mais intimidade com outras línguas, parecendo que domina não só o português, mas o estrangeiro também.

Se a população está agregando ao seu vocabulário cada vez mais palavras estrangeiras, enquanto desconhece a própria língua, o problema está no que causa isso tudo, e não na conseqüência. Estrangeirismo é apenas uma conseqüência da crescente convivência, absorvendo diversos costumes, com a cultura norteamericana. Herdamos muitas características do nosso vizinho estadunidense, como a arquitetura atual da cidade, o hábito de andar em grupos, tribos urbanas que provêm daquela cultura, há grande contato com a música norte-americana muito mais do que com a de outros países, as comidas rápidas ou semi-prontas, a grande audiência de filmes hollywoodianos etc. 
Tudo encaminha a uma interseção de línguas: em alguns pontos bem dosada, em outros, exageradamente inútil. Diante dessa relação costumeira do uso, mesmo que indevido, proibir estrangeirismos por lei seria tão inútil quanto proibir desvios gramaticais ou gírias. Será que realmente vale a pena este confronto? Não seria melhor pensar por que uma pessoa prefere um termo estrangeiro em vez do nacional? São pontos, logicamente, muito mais difíceis de serem tocados. Talvez por isso sejam ignorados.

Em nenhum lugar do mundo existe uma língua pura, pois o vocabulário de qualquer língua é resultado de séculos de intercâmbios com outros povos, outras culturas, e conseqüentemente, outras línguas. Como afirma Bagno (2001, p 73.), "lutar contra os empréstimos lingüísticos é uma luta perdida". Quanto ao uso das palavras inglesas na área de informática, o autor complementa dizendo que a compreensão ou não de uma palavra nada tem a ver com sua origem, com sua etimologia, com a língua de onde ela procede: tem a ver com a coisa ou o fato que ela designa, com o mundo de referências ao qual ela remete. Nem o cidadão mais culto e bem-informado poderá entender termos que não façam parte do seu universo de referências.

Toda língua viva varia e muda. E essa dinâmica revela muito bem a história dos empréstimos em qualquer língua. Eles chegam e, antes de se instalar, são empregados com sua forma original, causando estranheza. À medida que esse empréstimo vai-se incorporando por meio de decalques, traduções ou adaptações ortográficas, os indivíduos passam a tratá-los como itens léxicos constitutivos da língua de chegada, esquecendo-se, portanto, da sua origem.

Os anglicismos estão na língua porque a sociedade os usa, independentemente de que sejam considerados alienígenas ou elementos de 
integração. Só o fato de existirem é motivo suficiente para pensar que a mesma sociedade os aceita ou os rechaça segundo sua conveniência ou vigência.

A aparência ou característica inglesa que se pretende imprimir à língua portuguesa com o uso dos anglicismos traz à tona uma importante e preocupante constatação: a forte influência da cultura norte-americana sobre a cultura de países latinos, como o Brasil, por exemplo. Assim, a anglicização vocabular segue pareada à anglicização cultural. A relação língua-cultura-sociedade é muito evidente ao se abordar o tema anglicismo. A língua falada por um determinado grupo social reflete, sem dúvida, os seus valores e os seus pensamentos.

A dependência está atrelada a um posicionamento de inferioridade que tende à valorização dos países ingleses em detrimento do nosso próprio. Entremear palavras em inglês com palavras em português produz ao falante um sentimento momentâneo de glória, riqueza, prestígio e culturação. Isso, provavelmente, ocorre porque ainda não ultrapassamos o preconceito contra nós mesmos - contra as nossas origens. Somente quando nos valorizarmos como brasileiros, filhos de uma terra colonizada, mas que se desenvolveu ao longo de todos esses anos, nos orgulharemos da nossa língua que, afinal, como nós, é fruto de uma grande mistura de línguas - latim, grego, sânscrito, árabe, etc. Desse modo, seremos capazes de racionalizar o uso dos anglicismos, não os vendo como ameaças ou grandes dádivas - eles continuarão sendo o que sempre foram ,um recurso a mais à nossa linguagem.

A vida é uma transição própria, pois todos os momentos dela se dão em fases que configuram a transição. Estamos sempre mudando. Tudo muda, nada permanece sempre igual. E se o ser é dinâmico por natureza, a língua através da qual os seres humanos se expressam não poderia fugir a esse dinamismo. 
Então, a língua se constrói, a língua está sempre em construção, é um eterno movimento, é uma mudança perene, a sua situação é de um provisório, de um temporal que vai sempre se afeiçoando, se acomodando, se ajustando exatamente a uma conjuntura social, política, econômica, religiosa, ética, que vai sofrendo também transformações ao longo do tempo, de tal maneira, e, por conseguinte, de não acreditar no império soberano de uma determinada língua, ainda que ela tenha uma grande presença, e muito menos, na possibilidade de um pensamento único.

No uso comum, na fala transmitida, pode-se dizer que o importante é adequar a fala à situação de fala. Há um momento para cada palavra, há uma palavra para cada momento. A língua escrita, não. A língua escrita exige, como em vários momentos do convívio social, a língua escrita exige a variante sócio-cultural culta. Mas, acima de tudo, a identidade se faz na diferença. 


\section{METODOLOGIA}

Para o desenvolvimento deste trabalho, optou-se pelo uso da metodologia qualitativa, utilizando-se o método da análise documental e a observação sistemática.

\subsection{ANÁLISE QUALITATIVA}

A aplicação de métodos qualitativos torna possível evidenciar rapidamente as diversas interações a que estão submetidos os objetos de estudo; tais técnicas permitem aprofundar as variáveis em estudo, explorando e trazendo à tona um grande leque de possibilidades sobre os temas tratados; daí este tipo de pesquisa, também ser chamado de Pesquisa Exploratória.

Segundo Minayo (1992),

\footnotetext{
"a metodologia qualitativa é aquela que incorpora a questão do significado e da intencionalidade como inerentes aos atos, às relações e às estruturas sociais. O estudo qualitativo pretende apreender a totalidade coletada visando, em última instância, atingir o conhecimento de um fenômeno histórico que é significativo em sua singularidade". (Minayo, 1992, p.10)
}

Para Barbosa (1999, p.58), esta metodologia "pressupõe que um número limitado de casos é expressivo de uma situação social mais abrangente. Portanto, a lógica da pesquisa qualitativa é diferente dos métodos quantitativos". 
Os métodos qualitativos tratam as unidades sociais investigadas como totalidades que desafiam o pesquisador. Neste caso, a preocupação básica do cientista social é a estreita aproximação dos dados, de fazê-lo falar da forma mais completa possível, abrindo-se à realidade social para melhor apreendê-la e compreendê-la.

Se há uma característica que constitui a marca dos métodos qualitativos é a flexibilidade, principalmente quanto às técnicas de coleta de dados, incorporando aquelas mais adequadas à observação que está sendo feita.

Outra característica importante da metodologia qualitativa consiste na heterodoxia no momento da análise dos dados. A variedade de material obtido qualitativamente exige do pesquisador uma capacidade integrativa e analítica que, por sua vez, depende do desenvolvimento de uma capacidade criadora e intuitiva.

A metodologia qualitativa, mais do que qualquer outra, levanta questões éticas, principalmente, devido à proximidade entre pesquisador e materiais pesquisados. Ainda que a maioria dos pesquisadores (especialmente os sociólogos) dedique pouca atenção a essa questão, existe uma elaborada discussão — principalmente entre os antropólogos - que procura dar conta dos problemas decorrentes da relação de alteridade entre os dois pólos na situação de pesquisa.

\subsection{ANÁLISE DOCUMENTAL}

Foi utilizado o método de análise documental. O objetivo da análise documental é identificar, em documentos primários, informações que sirvam de subsídio para responder alguma questão de pesquisa. 
Por representarem uma fonte natural de informação, documentos "não são apenas uma fonte de informação contextualizada, mas surgem num determinado contexto e fornecem informações sobre esse mesmo contexto" (Lüdke \& André, 1986, p. 39). A análise documental deve ser adotada quando a linguagem utilizada nos documentos constitui-se elemento fundamental para a investigação.

A pesquisa documental é uma das técnicas decisivas para a pesquisa em ciências sociais e humanas. Ela é indispensável, porque a maior parte das fontes escritas - ou não escritas - são quase sempre a base do trabalho de investigação. Saint-Georges (1997, p. 30) considera que "a pesquisa documental apresenta-se como um método de recolha e de verificação de dados: visa o acesso às fontes pertinentes, escritas ou não, e, a esse título, faz parte integrante da heurística da investigação".

A pesquisa documental deve muito à História e sobretudo aos seus métodos críticos de investigação sobre fontes escritas. Cohen e Manion (1990, p. 75) esclarecem que "os últimos anos têm sido testemunhas de um processo de aproximação entre a investigação histórica e a investigação noutras áreas...”.

$\mathrm{E}$ isso acontece porque a investigação histórica, ao pretender estabelecer sínteses sistemáticas dos acontecimentos históricos, serviu sobretudo às ciências sociais, no sentido da reconstrução crítica de dados que permitam inferências e conclusões. Enfim, a possibilidade de, a partir de dados passados, perspectivar o futuro e a partir deste compreender os seus antecedentes, numa espécie de reconstrução (Cohen \& Manion, 1990).

A propósito das fontes documentais, existe uma grande aproximação na definição de conceitos, senão uma certa unanimidade em considerar as mesmas integradas na tipologia de fontes primárias e fontes secundárias. As primeiras como 
fontes de época, e as segundas como fontes interpretativas baseadas nas primeiras (Cohen \& Manion, 1990; Deshaies, 1997).

Adequando esta perspectiva às questões da educação, outros autores preferem designar as fontes documentais (oficiais) como documentos internos e como comunicações externas, considerando todos estes dados como muito importantes para os investigadores qualitativos (Bogdan \& Biklen, 1999).

Também Deshaies (1997, p.135-6) partilha desta idéia quando diz que "a grande variedade de materiais escritos e audiovisuais disponíveis não pode deixar de chamar a atenção dos investigadores...". Semelhante a esta perspectiva SaintGeorges (1997, p. 91-92) considera ainda, dentro das fontes primárias, as fontes deliberadas e as fontes inadvertidas, referindo que estas últimas são as "mais comuns e constituem, geralmente, a fonte primária mais valiosa". No mesmo sentido se expressam Cohen e Manion (1990, p. 85), quando afirmam "a importância de usar fontes primárias de dados quando for possível”. Na verdade, tudo isto tem o sentido expresso por Saint-Georges (1997, p. 17), quando afirma que se devem "considerar os documentos (escritos ou não) como verdadeiros fatos de sociedade".

A partir da visão abrangente do assunto, realizou-se seleção, síntese e julgamento dos dados e das informações, com base nas técnicas de análise documental e de análise de conteúdo. A análise documental supõe o estudo dos manifestos que registram a ocorrência dos fenômenos e as idéias motivadas por eles. O método histórico norteou a análise deste material que, conforme Richardson et al. (1985), "consiste em estudar os documentos visando investigar os fatos sociais e suas relações com o tempo sócio-cultural-cronológico." (p.182).

A análise de conteúdo foi implementada, logo após a análise documental. Segundo Richardson et al. (1985), essas duas técnicas apresentam aspectos 
complementares que possibilitam um conhecimento mais aprofundado dos fatos e dos fenômenos por meio do estudo dos documentos e dos conteúdos transcritos das entrevistas. Enquanto a análise documental preocupa-se com as temáticas contidas nos textos, a análise de conteúdo preocupa-se com as mensagens subjacentes aos temas abordados nos registros documentais.

\subsection{OBSERVAÇÃO SISTEMÁTICA}

Neste trabalho utilizou-se, ainda, a observação sistemática. Este tipo de observação é utilizado em pesquisas que têm como objetivo a descrição precisa dos fenômenos ou o teste de hipóteses. Pode, ainda, ocorrer em situações de campo ou de laboratório.

Antes da coleta de dados, o pesquisador elabora um plano específico para a organização e registro das informações. Isto implica estabelecer, antecipadamente, as categorias necessárias à análise da situação.

Para que as categorias sejam estabelecidas adequadamente, é conveniente que o pesquisador realize um estudo exploratório, ou mesmo estudos dirigidos à construção dos instrumentos para registro dos dados.

Bales mostrou, ainda, as limitações da observação sistemática, afirmando que, assim, o pesquisador está impossibilitado de ocultar a realização da pesquisa. Além disso, ele tem que ter tempo e preparação prévia das categorias a serem analisadas.

Como vantagem deste método, Bale aponta a facilidade de análise do material coletado. 


\subsection{MATERIAL ANALISADO}

Para a construção deste trabalho, analisou-se material jornalístico de grande circulação e importância nacionais, dos idiomas português (brasileiro) e espanhol (sul-americano). São eles:

Do Brasil

- Folha de S. Paulo

Do Chile:

- El Mercurio

Da Argentina:

- Clarín

Adquiriu-se um exemplar de cada um dos jornais acima mencionados veiculados no dia 16 de março de 2008, um domingo. Não houve um critério na seleção desta data, sendo escolhida aleatoriamente, apenas houve a preocupação de selecionar os jornais de Domingo por conter todas as editorias e informações da semana, além de contar com mais páginas.

Além da análise das edições impressas, investigou-se também a ocorrência de anglicismos nas versões on-line das edições de domingo dos mesmos jornais, $\begin{array}{llll}\text { sendo } & \text { Folha } & \text { (http://www.folha.uol.com.br/), } & \text { Clarín.com }\end{array}$ (http://www.clarin.com/) e El Mercurio (http://diario.elmercurio.com/).

Uma revolução tecnológica associada com a reestruturação do sistema capitalista levou a uma concentração no mercado de mídia e ao desenvolvimento de novos meios de comunicação, com destaque para a internet. Nos países em desenvolvimento, o ganho de escala e visibilidade com a inserção dos jornais em conglomerados de mídia tem ajudado a manter o lucro do setor. 
Para Ignácio Ramonet (1999), estamos vivendo num mundo em que todos se comunicam, chamado por alguns de "sociedade da informação", ou, conforme Milton Santos, "meio técnico.científico.informacional".

Ramonet relata que:

Os atores econômicos (empresas, patronato), políticos (governo, partidos, grupos), sociais (sindicatos, associações, organizações nãogovernamentais) ou culturais (teatros, óperas, centros culturais, casas de cultura, editores, livrarias) produzem informação, têm seu próprio jornal, seu próprio boletim, seus próprios responsáveis pela comunicação. (RAMONET, 1999)

Diferente de outros períodos da história, em que os custos de produção asseguravam o controle da informação a quem possuía rotativas ou sistemas de broadcasting, com a internet as ferramentas técnicas para a disseminação de informações estão ao alcance de qualquer um que disponha de conhecimento para isso. A competição pelo tempo de audiência do usuário de internet acontece entre grandes conglomerados e amadores em busca de 15 megabytes de fama ou movidos pelo desejo de se expressar.

Para Manuel Castells (2003b), pela primeira vez na história, surge uma capacidade de comunicação maciça e não midiatizada. Apesar de em termos de audiência e faturamento a Internet ainda refletir a concentração da mídia tradicional, exemplos de sucesso comercial fora do "main stream" já não são raros, embora muitas vezes o objetivo desta comunicação sem mediação seja não mercantil.

Ramonet acrescenta que cada vez mais esta capacidade de comunicação não mediatizada pela indústria está sendo utilizada. O teórico da comunicação e diretor da publicação francesa Le Monde Diplomatique complementa: 
Ao mesmo tempo em que as tecnologias da comunicação se desenvolvem, o número de grupos ou de indivíduos que comunicam é maior. Assim, a Internet permite a qualquer pessoa não só ser efetivamente, à sua maneira, jornalista, mas até encontrar-se à frente de uma mídia de alcance planetário. Matt Drudge, o homem que denunciou o caso Clinton-Lewinsky, mostrou isso muito bem, ele que não teve nenhum escrúpulo ao declarar: Sou um homem da multimídia. Não há nada mais enfadonho que ser obrigado a consultar os advogados antes de denunciar um caso. Prefiro fazer tudo eu mesmo. A Internet é tão romântica... Poder dizer o que se quer, tocar numa tecla e aí está. Seria estúpido renunciar a isto. (RAMONET, 1999, p.79).

Fazendo parte do sistema da mídia ou desafiando sua estrutura tradicional, as novas formas de comunicação on-line, suas implicações sociais e na indústria de mídia estão na pauta de empresários do setor e pesquisadores. Estas transformações não podem ser ignoradas. Castells (2003) chega a dizer que os sistemas de telecomunicações e a internet hoje são equivalentes à eletricidade da Era Industrial.

Estas ponderações confirmam a importância da mídia digital e, assim, a relevância da inclusão das edições on-line na análise do material.

Para compreender a escolha deste material, porém, faz-se necessário conhecer sua história, para que fique clara sua importância no cenário nacional em que circulam e, até mesmo, no cenário mundial. 


\subsubsection{FOLHA DE S. PAULO}

A história da Folha começa em 1921, com a criação do jornal "Folha da Noite". Em julho de 1925, é criado o jornal "Folha da Manhã", edição matutina da "Folha da Noite".

A "Folha da Tarde" é fundada após 24 anos. Em 1ํ de janeiro de 1960, os três títulos da empresa se fundem e surge o jornal Folha de S. Paulo.

1921: É fundado, em 19 de fevereiro, o jornal "Folha da Noite". O jornal criado por Olival Costa e seu sócio Pedro Cunha noticiava com prioridade as deficiências dos serviços públicos. Lançou campanhas pelo voto secreto e apoiou o tenentismo e o Partido Democrático. A Redação é instalada em uma sala, na rua São Bento, 66-A, no segundo andar de um prédio, na cidade de São Paulo.

1925: Em julho, é criado o jornal "Folha da Manhã", edição matutina da "Folha da Noite".

1931: Em janeiro, o jornal é vendido para Octaviano Alves Lima, cafeicultor, que prioriza a defesa dos interesses da lavoura, defende o liberalismo e se opõe ao Estado Novo. Lança campanhas pela saúde pública. A tiragem diária dos dois jornais sobe de 15 mil para 80 mil exemplares. Ainda em janeiro, o nome da companhia é alterado para Empresa Folha da Manhã.

1945: Em março, o controle acionário passa para as mãos de José Nabantino Ramos. É adotada a imparcialidade como política redacional. Os jornais, feitos para a classe média, defendem o ensino público e a cédula única.

1949: Em 1ํ de julho, é lançado o jornal "Folha da Tarde". 
1958: Em 10 de dezembro começa a circular a llustrada, caderno sobre cultura e variedades. A Folha já fazia cobertura de assuntos culturais desde a sua fundação, em 1921, mas não havia um caderno específico para esses temas.

1960: Em 1ํ de janeiro, os três títulos da empresa se fundem e surge o jornal Folha de S. Paulo.

1962: Em 31 de julho, Caio de Alcântara Machado é eleito presidente da empresa, deixando o cargo em 20 de novembro do mesmo ano. Em agosto, os empresários Octavio Frias de Oliveira e Carlos Caldeira Filho (1913-1993) assumem o controle acionário da Empresa Folha da Manhã.

1963: Em 15 de outubro é lançado o jornal "Notícias Populares". Dois anos depois, em 1965, o Grupo Folha incorpora o jornal.

1967: Em 19 de outubro, a "Folha da Tarde" volta a circular, o que não acontecia desde a unificação dos três jornais, em 1960. A Folha dá início à revolução tecnológica e à modernização do seu parque gráfico, que a colocarão na liderança da imprensa diária brasileira nos anos 80 .

1971: O jornal moderniza com o sistema de fotocomposição. Começa a impressão na Gross Metro-offset, recém-lançada nos EUA. É a rotativa mais avançada à época e a segunda maior do mundo, superada apenas pelo equipamento do "Daily Mirror", de Belfast, Irlanda.

1976: A Folha desempenha um papel decisivo no processo de redemocratização do Brasil, quando abre suas páginas ao debate de idéias que fervilhavam na sociedade civil. Em 22 de junho, começa a circular "Tendências/Debates", que abriga textos de intelectuais e políticos perseguidos pelo regime militar.

1981: Em junho, o documento de circulação interna "A Folha e alguns passos que é preciso dar" surge como a primeira sistematização de um projeto editorial. $\mathrm{O}$ texto 
fixa três metas: informação correta, interpretações competentes sobre essa informação e pluralidade de opiniões sobre os fatos.

1983: A Folha se torna a primeira redação informatizada na América do Sul com a instalação de terminais de computador para a Redação e edição de texto. É criado o Datafolha, instituto de pesquisa de opinião pública e de mercado, que faz levantamento de temas de interesse dos leitores e fornece informações à produção editorial.

1984: Em junho, surge o documento, também de circulação interna, "A Folha depois da campanha diretas-já", devido ao destaque do jornal na campanha em relação aos outros veículos de comunicação. O modelo proposto é o de um jornalismo crítico, pluralista, apartidário e moderno. A Folha implanta o Manual da Redação. Pela primeira vez, um manual de jornalismo condensa uma concepção de jornal, da política editorial às fases de produção.

1991: Em fevereiro, a Folha reorganiza o noticiário em novos cadernos de circulação diária. Além da llustrada, o jornal passa a oferecer os cadernos Brasil, Mundo, Dinheiro, Cotidiano e Esporte. A Folha é o primeiro órgão da imprensa brasileira a pedir o impeachment do presidente Fernando Collor de Mello, que renuncia no ano seguinte.

1992: O empresário Octavio Frias de Oliveira passa a deter a totalidade do controle acionário da companhia. Em janeiro, a Folha se consolida como o jornal com a maior circulação paga aos domingos, com uma média de 522.215 exemplares. A Primeira Página passa a circular colorida todos os dias e são criados o caderno Mais! e a Revista da Folha.

Anos 2000: A Câmara dos Deputados, em 22 de fevereiro de 2000, realiza sessão solene em homenagem ao Grupo Folha e ao seu publisher, Octavio Frias de 
Oliveira. Representantes dos principais partidos destacaram a contribuição da Folha à democratização do país. O Folha WAP, serviço que disponibiliza o noticiário e serviços da Folha Online para telefones celulares, é apresentado. É o primeiro produto desse tipo no Brasil. O jornal em tempo real Folha Online amplia substancialmente seu time de colaboradores e lança novos canais na sua home page, como "Pensata", que reúne artigos de vários colunistas, "Círculo Folha", com informações variadas sobre o Grupo Folha, e "Almanaque", site produzido pelo Banco de Dados que resgata textos de valor histórico publicados nos jornais do grupo. Começa a circular o jornal "Valor", especializado em economia e produto da associação do Grupo Folha, que edita a Folha, e da Infoglobo Comunicações, que publica "O Globo". A Folha passa a publicar uma compilação semanal de reportagens e artigos de alguns dos melhores jornais do mundo, como o "The New York Times", dos EUA, e o diário de economia britânico "Financial Times".

\subsubsection{EL MERCURIO}

É o jornal em circulação mais antigo do Chile e do mundo em língua espanhola, publicado ininterruptamente. Foi fundado em 1827 pelos tipógrafos Tomás G. Wells, norte-americano, Ignacio Silva Medina e Pedro Félix Vicuña, a primeira edição foi lançada em 12 de setembro do mesmo ano.

A editora de Valparaíso de El Mercurio foi fundada por Pedro Félix Vicuña, em 12 de setembro de 1827, e mais tarde foi adquirida por Agustín Edwards Ross, em 1880. A editora de Santiago foi fundada por Agustín Edwards Mac Clure, em junho de 1900. Em 1942 Edwards Mac Clure morreu e seu filho Agustín Edwards assumiu 
como presidente. Quando Augustin Eastman morreu em 1956, seu filho, Agustín Edwards Eastman, assumiu o controle da empresa.

\subsubsection{CLARÍN}

Fundado em 28 de agosto de 1945, em Buenos Aires, pelo jornalista, político e ex-ministro Roberto J. Noble (1902-1969). Trata-se de um jornal que atualmente é o líder entre os diários argentinos e que foi a semente do poderoso e influente conglomerado multimídia Clarín, maior do país e segundo no mundo hispânico.

A história e a evolução do jornal estão intimamente ligadas à vida do fundador, que acabou influenciando a conduta ética de seu jornal e de sua empresa, mesmo depois de sua morte, quando assume a direção a esposa Ernestina Laura Herrera de Noble, que transfere a gestão do grupo a Héctor Magnetto.

No início da década de 1970, Laura e Héctor fazem o grupo ter um grande salto empresarial, colocando-o entre as dez maiores empresas da Argentina e entre os três maiores grupos de mídia da América Latina e como segundo na América do Sul. Muitos episódios de sua relação com os governos militares e civis evidenciam os inúmeros favores recebidos pelo jornal, o que tornou possível sua hegemonia. Graças às benesses, o grupo conseguiu deter o controle do papel de imprensa, dando início ao monopólio, obter a Rádio Mitre AM e o Canal 13, burlando a legislação, além de subsídios e empréstimos oficiais.

Com a configuração multimídia, o grupo aposta na "convergência" e investe agora em suportes de ponta, nos quais também é líder - Internet, tevê por cabo e via satélite, telefonia móvel. Associado a grupos transnacionais ou competindo com eles, objetiva ingressar no setor da telefonia fixa. 


\subsection{NORMAS EDITORIAIS}

Com relação aos estrangeirismos, o manual de Redação do jornal Folha de São Paulo aconselha o seu uso apenas quando for indispensável, quando não houver outro termo em português ou quando o termo correspondente for pouco usado; mesmo nesses casos, deve-se preferir o termo já aportuguesado e não a grafia estrangeira. Ainda segundo o Manual, deve-se dar preferência, nos demais casos, ao equivalente em português e evitar o uso excessivo dos termos estrangeiros e das citações em outros idiomas, que tornam o texto pretensioso e pedante.

Não foram encontradas informações de manuais de redação dos jornais Clarín e El Mercurio.

Para proceder à definição/tradução dos termos coletados, recorreu-se aos seguintes dicionários: Dicionário Eletrônico Michaelis da Língua Portuguesa (2008), Michaelis - Dicionário de Inglês/Português, Português/Inglês (2006) e Dicionário Online de Anglisicmos (2008).

Neste trabalho, serão analisados tanto os empréstimos quanto os estrangeirismos, usando para isso a definição de Carvalho (1989), que explica que a introdução de um termo estrangeiro em um sistema lingüístico passa por quatro fases, sendo elas: 
PALAVRA ESTRANGEIRA (existente na língua A)

\section{$\downarrow$}

ESTRANGEIRISMO (usado na língua B)

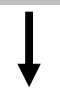

EMPRÉSTIMO (adaptação de qualquer tipo na língua B)
XENISMO (ausência de adaptação para a língua $B$ )

Carvalho (1989, p. 43) utiliza a dicotomia saussuriana langue/parole para explicar a diferença entre "estrangeirismo" e "empréstimo": o "estrangeirismo" faz parte da parole, sendo o seu uso individual, e o "empréstimo" passa a ser um elemento da langue, já devidamente socializado. Diz ela ainda que:

“... alguns empréstimos continuariam como fatos da parole, pois não são utilizados em novos enunciados e outros seriam da langue, pela freqüência de uso". (CARVALHO, 1989, p. 43)

Carvalho também faz uma outra distinção entre empréstimo e estrangeirismo, ressaltando que a diferença conceitual deve ficar bem clara. Ela compara os "empréstimos lingüísticos" aos "empréstimos monetários" feitos pelo Brasil, explicando que, "embora o governo brasileiro receba em dólares", estes são transformados em moeda nacional para uso no território brasileiro. Assim, o empréstimo é o estrangeirismo adaptado de várias formas.

Amancio (2006) também estabelece uma distinção entre "empréstimos lingüísticos" e "estrangeirismos". Ela define empréstimos lingüísticos como sendo termos ou estruturas de uma língua que se adaptaram e se integraram na língua que 
as recebeu e que, por isso, não produzem mais o efeito de estranhamento; não são mais sentidos como "de fora" da língua e sim considerados como parte integrante dela. Já os "estrangeirismos são definidos como sendo termos ou estruturas de uma língua, que são sentidos como estrangeiros na língua que os recebeu.

Amancio (2006) acrescenta ainda que nem sempre é fácil distinguir o empréstimo do estrangeirismo, mesmo quando há critérios lingüísticos (adaptação do vocábulo estrangeiro ao padrão da língua), de uso e práticos (a presença ou a ausência do termo nos dicionários da língua).

Para Amandio, a escolha do "empréstimo lingüístico" ou do "estrangeirismo" entre as formas de criação de vocábulos novos tem motivos de três ordens, que em geral explicam o uso do "estrangeirismo" em lugar do emprego de vocábulos criados com recursos da própria língua. São eles:

- Os contatos lingüísticos decorrentes da necessidade que têm os homens de interagir;

- A facilidade do empréstimo em relação à criação de novos termos;

- Os sentidos específicos dos vocábulos estrangeiros em relação aos outros neologismos e, conseqüentemente, os papéis diferenciados que tais termos assumem na organização persuasiva e argumentativa do discurso.

Corroborando a visão de Amandio, Alves (2004) explica que o estrangeirismo passa por algumas etapas até integrar-se à língua receptora. Primeiramente, o elemento estrangeiro é sentido como externo à língua vernácula, não fazendo parte do seu acervo lexical. Em seguida, o estrangeirismo é empregado juntamente com uma forma vernácula, sobretudo em textos escritos, com o objetivo de facilitar a compreensão do leitor. Essa forma traduzida pode tornar-se uma forma concorrente 
do estrangeirismo, alternando-se com ele; ou seja, num mesmo texto, para que não fique repetitivo, emprega-se ora o estrangeirismo ora o equivalente vernáculo.

Faraco (2004) define estrangeirismo como

O emprego, na língua de uma comunidade, de elementos oriundos de outras línguas. No caso brasileiro, posto simplesmente, seria o uso de palavras e expressões estrangeiras no português. Trata-se de fenômeno constante no contato entre comunidades lingüísticas, também chamado de empréstimo. A noção de estrangeirismo, contudo, confere ao empréstimo uma suspeita de identidade alienígena, carregada de valores simbólicos relacionados aos falantes da língua que origina o empréstimo. (FARACO, 2004, p.15)

$\mathrm{Na}$ tentativa de mostrar os estrangeirismos como enriquecedores da língua, Faraco (2004) afirma que:

Receber palavras de origem estrangeira em forma de empréstimo nada tem a ver com a soberania político-econômica. Os idiomas são palcos de mestiçagem e de interculturalidade e não devem ser vistos como baluartes ou fortalezas de nacionalidade, pois as naçõesestados contêm diferentes etnias com diferentes identidades. A presença de estrangeirismos na língua portuguesa de nenhuma forma ameaça a cultura brasileira, amplamente definida como literatura, música, teatro, folclore e dança. (FARACO, 2004, p. 104)

Faraco diz ainda que

... embora pareça fácil apontar, hoje, home banking e coffee break como exemplos claros de estrangeirismos, ninguém garante que, daqui a alguns anos, não estarão sumidos de bocas e mentes, como o match do futebol e o rouge da moça; assim como ninguém garante 
que não tenham sido incorporados naturalmente à língua, como o garçom, o sutiã, o esporte e o clube. (FARACO, 2004, p. 18)

Uma breve reflexão sobre o que é hoje parte legítima da língua, mas ontem não o foi, já indica que não é simples dizer como algo deixa de ser um estrangeirismo e passa a ser parte da língua da comunidade.

Como pudemos observar, os autores citados incluem os estrangeirismos como um dos processos de criação vocabular. É natural que um país carente de determinadas tecnologias importe-as de outro. E, ao se transferir a tecnologia, transfere-se também o termo que a denomina, razão pela qual ocorre a alta incidência de estrangeirismos na língua portuguesa do Brasil, cuja balança comercial ainda se caracteriza por exportar fundamentalmente matéria-prima e importar tecnologia, o que torna o país mais afeito à entrada de termos estrangeiros, fundamentalmente os anglicismos. 


\section{ANALISANDO OS ESTRANGEIRISMOS}

\subsection{FOLHA DE S. PAULO}

\subsubsection{REVISTA DA FOLHA}

A Revista da Folha é uma revista publicada aos domingos pelo jornal Folha de São Paulo. Conta com 34 páginas e traz variedades, matérias mundiais, fala de turismo e tem várias páginas destinadas à publicidade.

Desta edição de 16 de março de 2008 destacam-se os seguintes estrangeirismos:

Reportagem: O JAPÃO É POP

1) “O Japão é pop." (p. 08)

POP - Diz-se de uma estética primária procurada no objeto comum ou na sua utilização como matéria artística: Arte pop.(MICHAELIS, 2008)

Abreviatura da palavra inglesa popular, inicialmente relacionada com a música, mas que se estendeu a outras formas artísticas como a pintura. (Dicionário on-line de anglicismos, 2008)

2) "Um grafiteiro, uma banda de rock japonês, um baiano autor de mangá e uma dupla que se veste como personagens de animes formam um mosaico da cultura pop nipônica no cenário paulistano." (p. 08) 
ROCK - Dança de origem norte-americana, de compasso quaternário, surgida na década de 50. (MICHAELIS, 2008)

Gênero musical surgido nos EUA nos anos 50. (Dicionário on-line de anglicismos, 2008)

3) “... onda que invadiu a cidade por meio de um boom de eventos dedicados principalmente aos quadrinhos japoneses e às competições de cosplay, espécie de concurso de fantasia, com personagens de animes (animação japonesa)." (p. 09)

BOOM - Crescimento acelerado nos negócios ou na aceitação de um produto; período de expansão da economia; uma súbita elevação nos preços. (MICHAELIS, 2008)

Aumento súbito do mercado. (Dicionário on-line de anglicismos, 2008)

COSPLAY - não foi encontrado significado nos dicionários Michaelis ou no de anglicismos. Também não consta tradução do termo para o português nos dicionários pesquisados.

Segundo explicação encontrada na própria matéria da revista, cosplay é "uma espécie de concurso de fantasia, com personagens de animes (animação japonesa)" (FOLHA DE S. PAULO, 2008, p. 09).

4) "Artistas do gênero estão com suas agendas mais cheias, como atestam músicos, grafiteiros e performers entrevistados." (p. 10)

PERFORMERS - 1. executor, realizador, autor. 2 ator, músico, artista. (MICHAELIS, 2006)

5) "Passou a fazer capas de CDs e flyers para festas de hip hop." (p. 10) 
CDs - Sigla de compact disc. (MICHAELIS, 2008)

Disco compacto. (Dicionário on-line de anglicismos, 2008)

Compact disc (disco laser). (MICHAELIS, 2006)

FLYERS - 1 voador, pessoa ou coisa que voa, fugitivo, avião. 2 aviador. 3 veículo, trem, navio ou animal muito veloz. (MICHAELIS, 2006)

Pequenos folhetos publicitários com a função de anunciar e promover eventos, serviços ou instruções numa ampla gama de aplicações. (WIKIPEDIA, 2008). Com certeza este é o significado do termo no texto.

HIP HOP - Não foi encontrada em nenhum dos dicionários pesquisados. Buscados como termos separados "hip" e "hop" chega-se à tradução como "quadris dançantes" ou "dança dos quadris". Na Wikipédia encontra-se como definição "movimento cultural iniciado no final da década de 1960 nos Estados Unidos como forma de reação aos conflitos sociais e à violência sofrida pelas classes menos favorecidas da sociedade urbana. (WIKIPEDIA, 2008)

6) "A ponto de, na onda de festas e sites sobre o assunto, brasileiros sem vínculo nenhum como Japão mergulharem na idéia." (p. 11)

SITES - Local, página na internet que pode ser acedido através de um endereço. (Dicionário on-line de anglicismos, 2008)

Posição, lugar, terreno. (MICHAELIS, 2006)

Reportagem: DEU NO “THE NEW YORK TIMES”

1) "Quem descobriu o vilarejo baiano foram os surfistas." (p. 14)

SURFISTA - Praticante do surfe. (MICHAELIS, 2008) Nota-se que aqui a palavra "surf" é escrita "surfe", já adaptada à língua portuguesa. 
Desporto aquático nascido na Califórnia nos anos 60. (Dicionário on-line de anglicismos, 2008)

O termo surfista não consta no dicionário de inglês, mas a palavra surf traz o seguinte significado: Rebentação, arrebentação, espuma de ondas. Sports surfar, praticar surfe. (MICHAELIS, 2006)

2) “... há opções para saciar a sede de aventura dos mais empolgados: rapel, rafting, canoagem, mountain-bike e arvorismo." (p. 14)

RAPEL - não foi encontrado em qualquer dos dicionários pesquisados. $\mathrm{Na}$ Wikipédia é definido como uma atividade radical praticada com uso de cordas e equipamentos adequados para a descida de paredões e vãos livres bem como outras edificações. (WIKIPEDIA, 2008)

RAFTING - Viajar em ou transportar com balsa, jangada. (MICHAELIS, 2006). É conceituado como "prática de descida em corredeiras em equipe utilizando botes infláveis, equipamentos de segurança." (WIKIPEDIA, 2008)

MOUNTAIN-BIKE - Pesquisados como termos separados, mountain-bike pode ser traduzido como "bicicleta de montanha" (MICHAELIS, 2006). Pode ser explicado como uma modalidade de ciclismo fora de estrada na qual o objetivo é transpor percursos com diversas irregularidades e obstáculos. (WIKIPEDIA, 2008)

Reportagem: QUERO MINHA PARTE EM DINHEIRO

1) "Essas promoções saem todas de cabecinhas muito criativas do pessoal de marketing." (p. 19)

MARKETING - 1 Comercialização. 2 Execução de todos os atos de comércio que sirvam para dirigir o escoamento de mercadorias e serviços do produtor ao 
consumidor. 3 Conjunto de operações que envolvem a vida do produto, desde a planificação de sua produção até o momento em que é adquirido pelo consumidor. (MICHAELIS, 2008)

Estratégias de venda de idéias ou produtos. (Dicionário on-line de anglicismos, 2008)

Mercadologia (MICHAELIS, 2006)

2) "Uma vez, o $\boldsymbol{D} \boldsymbol{j}$ Mauro Borges, no meio de uma crise, jogou notas de $\mathrm{R} \$ 50,00$ para o público." (p. 19)

DJ - Disc-jockey Pessoa encarregada de escolher e passar a música a ser ouvida numa discoteca. (Dicionário on-line de anglicismos, 2008)

1 locutor de rádio de programas musicais. 2 pessoa que seleciona e apresenta a programação musical de casas noturnas. 3. Locutor. (MICHAELIS, 2006)

3) "Os marqueteiros ainda inventam alguns termos para valorizar mais esses eventos." (p. 19)

MARQUETEIROS - pessoa ou profissional do marketing. (MICHAELIS, 2008) O termo, todavia, é quase sempre utilizado pela imprensa para designar especificamente aqueles profissionais que fazem "marketing político".

Reportagem: POR ONDE ANDAS?

1) "A Revista convidou cinco paulistanos para fazer o test-drive das calçadas da cidade." (p. 20)

TEST-DRIVE - Teste de um produto. (Dicionário on-line de anglicismos, 2008)

Dirigir um veículo para testá-lo, antes de comprá-lo. (MICHAELIS, 2006) 
2) "Em uma tarde ensolarada, a dupla aceitou o convite para dar uma volta pelas ruas dos Jardins que se converteram em um shopping a céu aberto." (p. 22)

SHOPPING - Centro comercial. (Dicionário on-line de anglicismos, 2008)

1 compra. 2 ato de fazer compras. (MICHAELIS, 2006)

Estrutura que contém estabelecimentos comerciais como lojas, lanchonetes, restaurantes, salas de cinema, playground ${ }^{2}$, parques de diversões e estacionamento, caracterizado pelo seu fechamento em relação à cidade. (WIKIPEDIA, 2008).

\section{MATÉRIAS PUBLICITÁRIAS:}

1) Até $60 \%$ off.

OFF - Desligado. (MICHAELIS, 2008)

Apesar da tradução literal da palavra ter o significado de desligado, no contexto da frase o significado real refere-se a desconto, promoção. (Dicionário on-line de anglicismos, 2008)

2) Jantar especial preparado pelo chef Olivier Cosan.

CHEF - Cozinheiro-chefe. (MICHAELIS, 2008)

3) Cover The Beatles.

COVER - 1 coberta, cobertura. 2 tampa. 3 cobertor. 4 invólucro, envoltório. 5 capa de livro. 1 cobrir, tampar. 2 cobrir a superfície de. 3 abrigar, proteger. 4 incluir, abranger. (MICHAELIS, 2008)

\footnotetext{
${ }^{2}$ Nota-se que, nesta definição de shopping, pode ser encontrada a palavra playground, que também é um anglicismo.
} 
Aqui surge uma surpresa, porque a tradução não condiz com o significado que a palavra tem quando usada em uma frase na língua portuguesa. A palavra cover é definida como "imitação", principalmente de cantores e/ou bandas famosas. (Dicionário on-line de anglicismos, 2008)

4) Jet ski, passeios de barco, caiaque, windsurf, (...), tênis, bicicleta, vôlei de praia.

JET SKI - Jet - 1 jato, jorro. (MICHAELIS, 2008).

Ski - esqui. (MICHAELIS, 2008). Aqui percebe-se a incorporação da palavra à língua portuguesa, inclusive com adaptação em sua ortografia. Segundo o dicionário, a palavra esqui significa: Espécie de patim que consiste numa tábua estreita e comprida, um pouco levantada na ponta e que serve para deslizar sobre a neve. (MICHAELIS, 2007)

O composto "Jet ski" não foi encontrado em nenhum dos dicionários, nem de português nem de inglês. Utilizando-se da tradução de suas partes, conclui-se que é um esqui a jato. A única definição encontrada na enciclopédia é que é um "meio de transporte para andar na água". (WIKIPEDIA, 2008)

WINDSURF - a palavra não foi encontrada. Buscando suas partes temos:

Wind - vento. (MICHAELIS, 2008)

Surf - rebentação, espuma de ondas. (MICHAELIS, 2008)

A enciclopédia define como prancha à vela, podendo ser chamado também de surfe (aqui novamente em sua forma adaptada à língua portuguesa) a vela. (WIKIPEDIA, 2008) 
TÊNIS - esta palavra já está totalmente incorporada à língua portuguesa e já nem aparece nos dicionários de inglês, apesar de sua origem. A palavra tennis (em inglês) apresenta como tradução o termo tênis, nosso velho conhecido. (MICHAELIS, 2008).

O dicionário de língua portuguesa explica o termo:

1 Jogo praticado com bola e raquete, em campo dividido ao meio, transversalmente, por uma rede. 2 Calçado esportivo confeccionado em lona e com solado de borracha. (MICHAELIS, 2007)

VÔLEI - assim como a palavra anterior, esta apresenta-se grafada já adaptada à língua portuguesa. Nos dicionários de idiomas, o termo volley (em inglês) mostra a tradução: vôlei. (MICHAELIS, 2008)

O dicionário de língua portuguesa, mais uma vez, explica o significado:

Jogo que, numa quadra dividida transversalmente ao meio, por uma rede suspensa, é disputado por duas turmas (uma de cada lado da rede, com seis integrantes cada), as quais, com um máximo de três batidas, sem que cada jogador possa bater duas vezes seguidas, procuram passar, com as mãos, ou o punho, uma bola que deve bater no chão da quadra adversária, o que naturalmente a turma desta faz o possível para evitar. (MICHAELIS, 2007)

5) kits para bebê.

KIT - 1 estojo. 2 conjunto de instrumentos. (MICHAELIS, 2008) 


\subsubsection{CADERNO PRINCIPAL}

\section{CAPA}

1) As commodities estão em seu sétimo ano seguido de alta, puxadas pelo crescimento da economia global.

COMMODITIES - mercadorias, no sentido de produtos primários ou básicos, como café, algodão, açúcar, trigo e minérios etc. (Econogloss, 2008)

Esta palavra não foi encontrada no dicionário de inglês.

2) Sexo, mentiras e videotape.

VIDEOTAPE - No dicionário de inglês, a palavra videotape recebe como tradução: videoteipe. (MICHAELIS, 2008)

Gravação simultânea de som e imagem em fita magnética, a qual permite reproduções futuras de cenas que podem passar como atuais em relação ao momento da transmissão. (MICHAELIS, 2007)

3) Internet rápida leva TV paga a crescer 13\%.

INTERNET - não foi encontrada no dicionário de inglês.

Segundo o dicionário da Língua Portuguesa, internet é uma rede remota internacional de ampla área geográfica, que proporciona transferência de arquivos e dados, juntamente com funções de correio eletrônico para milhões de usuários ao redor do mundo. (MICHAELIS, 2008) 


\section{OPINIÃO}

1) Batia os olhos nas notícias on-line sobre trânsito e via a informação de cem ou pouco mais quilômetros de congestionamento.

ON-LINE - não foi encontrada a expressão, apenas as palavras em separado, que podem ser traduzidas como "na linha". (MICHAELIS, 2008)

2) o e-mail, que deu oportunidade à comunicação de forma surpreendente, se, de um lado, está servindo na busca e na troca de informações para aproximar pessoas, de outro, está produzindo chatos em massa, em escala industrial.

E-MAIL - correio eletrônico (MICHAELIS, 2008)

A palavra também foi encontrada no dicionário de língua portuguesa, trazendo exatamente o mesmo significado: correio eletrônico. (MICHAELIS, 2007).

\section{PAINEL DO LEITOR}

1) A Folha fez por merecer seu próprio slogan.

SLOGAN - no dicionário de inglês: frase, palavra de propaganda. (MICHAELIS, 2008)

No dicionário de língua portuguesa: 1 Divisa, lema, legenda, mote (de um grupo, de um partido etc.). 2 Frase concisa, de fácil percepção e memorização, que resume as características de um produto ou serviço, ou uma de suas qualidades ou ponto de venda, usada e repetida inalteradamente nos anúncios de uma firma. (MICHAELIS, 2007) 
BRASIL

1) O Ministério da Saúde lança, nesta semana uma cartilha para os parlamentares, alvo de intenso lobby dos fabricantes.

LOBBY - No dicionário de inglês: 1 pessoa ou grupo que procura influenciar legisladores. 2 grupo de pessoas que se unem a favor ou contra alguma ação. 3 Fazer lobby, tentar obter a aprovação de um projeto ou de uma lei na câmara, mediante pedido de votos. 4 pedir votos a membros da câmara. 5 tentar influenciar. (MICHAELIS, 2008)

$\mathrm{Na}$ língua portuguesa encontra-se: Pessoa ou grupo que tenta influenciar os congressistas (deputados e senadores) a votar projetos de seu interesse, ou de grupos que representam. (MICHAELIS, 2007)

Curiosamente, no dicionário de língua portuguesa encontra-se ainda: lobista Pessoa que exerce lóbi (aqui escrito como é pronunciado). (MICHAELIS, 2007)

\section{2) Ombudsman}

OMBUDSMAN - no inglês: funcionário designado para receber e investigar reclamações dos cidadãos contra órgãos governamentais ou empresas. (MICHAELIS, 2008)

$\mathrm{Na}$ língua portuguesa: 1 Nos países de democracia avançada, funcionário do governo que investiga as reclamações do povo contra os órgãos administrativos. 2 Pessoa incumbida de observar e criticar as falhas de uma empresa, pondo-se no lugar do público. (MICHAELIS, 2007) 
3) Alguns leitores tomaram a charge que acompanhou o texto, (...) como uma afronta às mulheres.

CHARGE - surpreendentemente, esta palavra tem diversos significados em inglês: 1 carga de pólvora, carga explosiva. 2 cargo, ofício, dever, responsabilidade, obrigação. 3 cuidado, encargo, custódia. 4 pessoa ou coisa sob cuidados de alguém, protegido, afilhado. 5 ordem, incumbência, direção, comando. 6 carga, fardo. 7 instrução, exortação. 8 acusação formal. 9 preço de venda, custo. 10 encargo financeiro, despesa, ônus. 11 ataque, assalto, carga, investida. 12 sinal de ataque. 13 carga elétrica, carga de bateria, de acumulador etc. 14 divisa. 15 falta no jogo de futebol. 16 lançamento de débito. (MICHAELIS, 2008) Apesar de tantos significados, percebe-se que nenhum deles refere-se ao significado da palavra na frase. Este significado foi encontrado apenas no dicionário de língua portuguesa: caricatura. (MICHAELIS, 2007)

4) Não é função do cartum ser fiel a estudos.

CARTUM - aqui está um anglicismo incorporado à escrita portuguesa. Em inglês, a grafia é cartoon, e significa: 1 desenho executado sobre papel forte para servir de modelo a diversas obras, tais como tapeçaria, mosaico, pintura a fresco. 2 caricatura. 3 desenho animado. desenhar caricaturas. (MICHAELIS, 2008)

O dicionário de língua portuguesa traz a grafia "cartum", acompanhada do significado: Narrativa humorística expressa através de caricatura e normalmente destinada a público em jornais e revistas; anedota gráfica. (MICHAELIS, 2007)

5) Menos usual, mas também cabível no caso, é a mensagem de atração de simpatia a ser valorizada pelo status do mensageiro. 
STATUS - em inglês: estado, condição. 2 cargo, posição social, status, prestígio. 3 posição legal. (MICHAELIS, 2008)

Em língua portuguesa: 1 Posição do indivíduo no grupo (ou do grupo noutro maior de que faça parte), determinada pelas relações com todos os outros membros através de competição consciente. 2 Posição legal de um indivíduo. (MICHAELIS, 2007)

MUNDO

1) A firma é a $13^{\underline{a}}$ no ranking das cem mais prestigiadas do país.

RANKING - classificação, categorização. (MICHAELIS, 2008)

No dicionário de língua portuguesa encontra-se: Seqüência de classificação (de atletas e jogadores). (MICHAELIS, 2007)

\subsubsection{MAIS!}

Reportagem: "ROLETA RUSSA"

1) Um thriller com algo do melodrama.

THRILLER - apresenta o mesmo significado nos dois idiomas. Em inglês: 1 história, romance, filme ou peça de suspense. 2 algo que emociona ou deixa tenso. (MICHAELIS, 2008)

$\mathrm{Na}$ língua portuguesa: Enredo de filme, peça, narrativa etc. que inspira horror. (MICHAELIS, 2007) 
Reportagem: VIAGENS INSÓLITAS

1) A recusa da identidade gay não é expressão de livre escolha, mas sintoma de opressão.

GAY - em inglês encontra-se: 1 alegre, divertido, jovial. $\mathbf{2}$ vistoso, brilhante, vivo. $\mathbf{3}$ prazenteiro, festeiro. 4 lascivo, dissoluto. 5 homossexual, relativo a homossexual. (MICHAELIS, 2008)

No dicionário de língua portuguesa a palavra grafada como "gay" traz como resultado: "guei", que significa 1 Homossexual masculino. 2 Veado, bicha. (MICHAELIS, 2007)

\section{Reportagem: GATO PINGADO}

1) O anúncio de que já passou da hora do jantar encontra Robert Crumb, nome lendário dos quadrinhos underground, centrado.

UNDERGROUND - em inglês: 1 subterrâneo. 2 subsolo. 3 movimento de resistência. 4 trem subterrâneo, metrô. 5 vanguarda cultural, contracultura. 1 subterrâneo, subtérreo. 2 secreto. 3 de resistência ou oposição secreta. 4 que atua na vanguarda cultural ou na contracultura. 1 debaixo da terra, no subsolo. 2 em segredo, às escondidas, ocultamente, secretamente. (MICHAELIS, 2008)

$\mathrm{Na}$ língua portuguesa tem-se: Movimento ou organização que funciona secretamente e cuja finalidade, geralmente, é destruir a autoridade estabelecida ou a força inimiga invasora de um território. (MICHAELIS, 2007)

Aqui, percebe-se que o significado em inglês não traz exatamente a mesma idéia da frase em língua portuguesa, apontando para que o anglicismo serviu como inspiração para nomear o movimento contra os invasores mas, em sua origem, não significa exatamente isso. 


\section{Reportagem: O GORDO E O MAGRO}

1) Uderzo sonha com o "american way of life" dos anos 50.

AMERICAN WAY OF LIFE - modo de vida americano. (MICHAELIS, 2008).

Aqui, o que temos não é um anglicismo, mas uma expressão que poderia ter sido escrita na língua portuguesa, já que tem correspondentes perfeitos, mas que o autor preferiu escrever em inglês, dando destaque ao sentido da frase.

Reportagem: MUTANTES ENTRE NÓS

1) O super-humano Wolverine e a vilã mutante Mística.

SUPER - o dicionário de inglês não traz o correspondente em língua portuguesa, mas explica o significado da palavra: 1 (artista) extranumerário. 2 superintendente. $\mathbf{3}$ objeto, projeto de qualidade e tamanho superior. 4 excelente, formidável. (MICHAELIS, 2008)

Em língua portuguesa tem um significado sucinto, porém claro: Exprime a idéia de superioridade (MICHAELIS, 2007)

2) Alguns indivíduos usam alguns hotspots mais que outros.

HOTSPOTS - esta palavra não foi encontrada em nenhum dicionário pesquisado. Seu significado pôde ser encontrado apenas na própria matéria de jornal, que explica que hotspots são pontos específicos do genoma que, recombinados, alteram informações genéticas, alterando o DNA do indivíduo, que terá descendentes com características genéticas diferentes das suas. 
Talvez por ser um tema ligado à ciência e ser o inglês o idioma dominante nesta área, ainda não exista na língua portuguesa (e talvez nunca chegue a existir) uma palavra correspondente.

\section{Reportagem: O CARA-METADE}

1) Ele tem pele clara, tem "traços europeus", fala com sotaque americano "standard" impecável.

STANDARD - no inglês: 1 padrão, critério, protótipo, modelo, regra, norma, medida, nível. 2 medida ou peso padrão. 3 bandeira, emblema, símbolo, estandarte. 4 suporte, coluna. 5 árvore ou arbusto com um tronco liso e direito. 6 base, pedestal. 7 padrão, que serve de padrão. 8 excepcional, modelar, exemplar. 9 legal, oficial. 10 clássico. 11 normal, comum. (MICHAELIS, 2008)

Curiosamente, no dicionário de língua portuguesa, a palavra "standard" aponta para seu correspondente "estândar" (praticamente desconhecido), que significa: Tipo ou modelo uniforme de produção; padrão, paradigma. (MICHAELIS, 2007)

\subsubsection{ESPORTES}

Reportagem: CLÁSSICO CONFUNDE PAPÉIS EM RIBEIRÃO

1) Não tivemos nenhum pênalti a nosso favor.

PÊNALTI - esta palavra já ganhou uma escrita "aportuguesada". No inglês é penalty: 1 pena, penalidade, punição, multa. 2 desvantagem, perda. 3 pênalti, penalidade máxima. (MICHAELIS, 2008) 
Com a grafia encontrada na frase, o dicionário de língua portuguesa traz o seguinte resultado: Em futebol, infração praticada por um jogador dentro da grande área de seu próprio clube e punida com a penalidade máxima (MICHAELIS, 2007)

2) Diz o superintendente de futebol.

FUTEBOL - também já totalmente adaptada à língua portuguesa, chega-se a esquecer que sua origem é inglesa. Football: 1 futebol. 2 bola de futebol. $\mathbf{3}$ qualquer jogo ou bola como a de futebol. (MICHAELIS, 2008)

Bem explicado na língua portuguesa: Jogo entre dois grupos de onze jogadores, em campo retangular, onde cada grupo procura fazer entrar uma bola no gol adversário, sem Ihe tocarem com a mão, tantas vezes quantas forem possíveis, durante os noventa minutos de prática. (MICHAELIS, 2007)

Reportagem: ‘EPIDEMIA’ DE LESÕES MUSCULARES ASSOLA O SÃO PAULO

\section{1) Pocket show.}

POCKET SHOW - segundo o dicionário de inglês, pode ser traduzido como "mostrar o bolso". (MICHAELIS, 2008)

No dicionário de língua portuguesa não foi encontrado significado.

Recorrendo à enciclopédia é que foi possível descobrir que se refere não a "mostrar o bolso", mas a um "show de bolso". Show aqui com o significado de espetáculo (MICHAELIS, 2007) e a expressão "de bolso" no sentido de curta duração.

2) Filé (...) levou o seu know how.

KNOW HOW - no inglês: experiência, técnica, prática, perícia (MICHAELIS, 2008) 
Na língua portuguesa: Técnica e prática eficientes num processo de produção. (MICHAELIS, 2007)

O Econogloss (2008) explica como: experiência técnica, saber fazer. Utiliza-se geralmente nos processos de fabricação não patenteada, mas que exige uma grande habilidade. Também se aplica a um conjunto de operações que exigem experiência em várias especialidades.

Reportagem: ERA BOM, MAS NEM TANTO

1) O doping era mais comum que hoje.

DOPING - o inglês não aponta uma tradução, mas explica o significado: 1 Turf doping: injeção ilícita de uma droga estimulante no animal de corrida a fim de assegurar-Ihe a vitória. (MICHAELIS, 2008)

Assim como na língua portuguesa: 1 Uso ilegal, por um atleta, de substâncias químicas que the aumentem o desempenho. 2 Aplicação ilegal de substâncias químicas num cavalo, para aumentar seu desempenho na corrida. (MICHAELIS, 2007)

\subsubsection{ILUSTRADA}

Reportagem: FICÇÃO DILUÍDA RESISTE NA BAHIA DE NOSSOS DIAS

1) Agora, a palavra surge mais relacionada ao badalado restaurante freqüentado por vips locais.

VIPS - este é um verbete especial. Na verdade, ele nasceu de uma abreviação: V.I.P. (very important person), que significa: pessoa muito importante (MICHAELIS, 2008) 
Ou, na língua portuguesa: Pessoa de prestígio considerável. (MICHAELIS, 2007)

2) ... virou uma galeria de lojinhas e um hotel.

HOTEL - este é outro verbete que está totalmente incorporado à língua portuguesa que até é possível esquecer que é de origem (e grafia) do inglês, tanto que a referência no dicionário de inglês é exatamente a mesma: hotel. (MICHAELIS, 2008)

3) Seus vários ambientes - bar, reprodução do quarto da cafetina Maria Machadão...

BAR - assim como no caso acima, este verbete está incorporado à língua portuguesa e o dicionário aponta como tradução a mesma palavra (MICHAELIS, 2008)

Reportagem: ESCRITOR ERA COMO SEUS PERSONAGENS, DIZ CAETANO

1) Gosto de Jorge Amado como gosto de Fellini e de axé music.

MUSIC - no inglês: música (MICHAELIS, 2008)

Esta palavra tem um correspondente perfeito na língua portuguesa mas o mundo artístico opta em usar a expressão em inglês para designar estilos musicais.

\section{Reportagem: EX-'FRIENDS' SE ISOLA EM NOVA SÉRIE}

1) $\mathrm{Na}$ ocasião, Matthew vinha trabalhando em um personagem esquizofrênico inspirado em um software que simulava os efeitos da esquizofrenia.

SOFTWARE - mais um verbete onde o dicionário não aponta um correspondente na língua portuguesa, mas descreve seu significado: suporte lógico, suporte de programação. Conjunto de programas, métodos e procedimentos, regras e 
documentação relacionados com o funcionamento e manejo de um sistema de dados. (MICHAELIS, 2008)

A palavra é encontrada com facilidade no dicionário de língua portuguesa, trazendo o mesmo significado que o dicionário de inglês. (MICHAELIS, 2007)

Reportagem: NERD DESAJEITADO QUER SER POPULAR EM SÉRIE DA TV PAGA

1) A trama é centrada nas desventuras de Rusty, um garoto nerd e desajeitado. NERD - Apesar de não haver sido encontrada nos dicionários de inglês ou de língua portuguesa, a enciclopédia contribuiu com uma explicação enriquecedora, que diz que a expressão é derivada de Northern Electric Research and Development (Departamento de Pesquisa e Desenvolvimento da companhia Northern Electric do Canadá, hoje Nortel), ou seja, atribuída àqueles indivíduos que trabalhavam no laboratório de tecnologia, que eram dados a passar noites em claro nas suas pesquisas. Na década de 1960 difundiu-se a sua conotação pejorativa, aplicado a pessoas com inteligência geralmente acima da média, com alguma dificuldade em se relacionar socialmente, e que não obedece aos padrões, principalmente físicos e intelectuais, da sociedade, tornando-se uma pessoa marginalizada, tímida e solitária. Atualmente, no entanto, o termo nerd vem sendo usado por determinados grupos relacionados a interesses específicos como forma de se identificarem.

\section{OUTRO CANAL}

1) O reality show "Big Brother Brasil" deixou de ser um programa odiado por atores. 
REALITY SHOW - pode ser traduzido como espetáculo da vida real (MICHAELIS, 2008), que poderia ser usado sem prejuízo do significado da frase mas, por modismo, prefere-se usar o termo americanizado.

2) Para desespero dos figurinistas, não há quem o convença a trocar o "conjuntinho" short vermelho/camisa amarela.

SHORT - em tradução literal significa: 1 curto. 2 breve. 3 baixo, pequeno, não alto. 4 restrito, de pouco alcance. 5 insuficiente, pouco. 6 deficiente, inadequado. 7 limitado, escasso. 8 conciso, resumido. (MICHAELIS, 2008)

$\mathrm{Na}$ língua portuguesa, utilizando-se da mesma grafia, explica-se como 1 Tipo de calção esportivo usado por homens e mulheres. (MICHAELIS, 2008)

3) Não deixa de ser sexy, é só outro ponto de vista.

SEXY - o dicionário de inglês explica como: 1 sexualmente atraente, erótico. 2 excitante. (MICHAELIS, 2008)

Já o dicionário de língua portuguesa explica: Que possui sex-appeal; vamp. (MICHAELIS, 2008)

Aqui percebe-se que o dicionário de inglês foi mais explicado que o de língua portuguesa, que se utilizou de outros anglicismos para explicar o verbete.

\section{4) O Pequeno Pônei}

PÔNEI - aqui já bem aportuguesada, a palavra pônei deriva de pony (MICHAELIS, 2008) 
Pônei, na língua portuguesa, explica-se como cavalo muito pequeno (altura $1 \mathrm{~m}$ a 1,45 m), ágil e fino, de várias raças, sendo as mais conhecidas as das llhas Shetland e da Islândia. (MICHAELIS, 2007)

Este é um exemplo de anglicismo que teve a grafia adaptada às normas da língua portuguesa.

\subsubsection{DINHEIRO}

Reportagem: RECEITA COM COMMODITIES DEVE CHEGAR A US \$ $100 \mathrm{BI}$

1) O Brasil deve ter receita record (...) este ano.

RECORD - o inglês explica como 1 registro, inscrição, anotação (MICHAELIS, 2008) Já o dicionário de língua portuguesa traz o verbete adaptado ao idioma. Recorde: 1 Ato desportivo, devidamente homologado, que supera tudo o que, no mesmo gênero, se fez anteriormente. 2 Proeza inaudita. 3 Ponto máximo. (MICHAELIS, 2007)

Reportagem: MINÉRIO DE FERRO DEVE RENDER $61 \%$ A MAIS

1) ... este ano deve apresentar deficit de US $\$ 1,150$ bilhão.

DEFICIT - o dicionário de inglês traduz como: déficit (com acento), deficiência. (MICHAELIS, 2008)

O dicionário de língua portuguesa explica como 10 excesso da despesa em relação à receita, em um orçamento; saldo negativo entre a receita e a despesa num orçamento. 2 O que falta numa conta, provisão, receita etc. (MICHAELIS, 2008) 
Reportagem: BANDA LARGA PUXA TV POR ASSINATURA, QUE CRESCE 13\% EM 2007

1) Na esteira do "triple play", o NetFone via Embratel teve expansão de $212 \%$.

TRIPLE PLAY - pode ser traduzido como: jogo triplo. (MICHAELIS, 2008) No texto, refere-se a telefone, internet e TV por assinatura.

2) Sobre o fim do pagamento mensal pelo ponto extra, quando a manutenção do equipamento não for feita pela operadora, Annemberg reitera que a norma foi mal redigida e nada muda em junho.

EXTRA - o inglês traz como tradução: 1 extraordinário. 2 acréscimo, aumento. (MICHAELIS, 2008)

A lingual portuguesa explica como Forma abreviada de extraordinário (MICHAELIS, 2007)

\subsection{CLARÍN}

\subsubsection{CAPA E CONTRACAPA}

1) Test de los Pumas ofrece revancha

TEST - 1 prova, exame, teste, determinação de presença, de qualidade. (MICHAELIS, 2008)

Em espanhol usa-se a mesma grafia: test. 
2) Escocia tendrá chances de vengar la derrota de los cuartos de final em La Copa Mundial de rugby...

RUGBY - Tanto no dicionário de inglês quanto de português o verbete é explicado apenas como um esporte.

3) Descubrem que los marcapassos son vulnerables a los hackers.

HACKERS - 1 pessoa capaz de desempenhar uma tarefa de forma competente. 2 alguém que gasta muitas horas com o computador, operando-o por tentativa e erro sem auxílio de manual. 3 pessoa que usa seu conhecimento técnico para ganhar acesso a sistemas privados. (MICHAELIS, 2008)

A palavra não aparece no dicionário de inglês.

4) El clown trae su compañía teatral a Buenos Aires ...

CLOWN - o inglês aponta como tradução a palavra payaso, mostrando que há um correspondente em espanhol que poderia ser usado no texto.

5) Se tratan además, manejo de correspondência, atención al público, organización de agendas, follow up telefónic, correo electrónico e internet, transmisión y recepción de fax por PC.

FOLLOW UP - é traduzida como "atendimento".

INTERNET - a palavra não foi encontrada no dicionário de espanhol, apesar de ser usada e compreendida.

FAX - não existe tradução para o espanhol. A palavra usada é a mesma nos dois idiomas. 
6) ... Dyseño web y diseño gráfico ...

WEB - da mesma maneira que a palavra anterior, não existe tradução. A palavra em inglês é usada no espanhol sem adaptações.

7) Especialidades: motores diésel, electricidad, ...

DIÉSEL - a diferença entre os idiomas inglês e espanhol é apenas o acento usado no idioma latino.

\subsubsection{EL PAÍS}

Reportagem: LA POLICÍA PORTEÑA TENDRÁ SALARIO ALTO, CASA Y TECNOLOGÍA DE PUNTA

1) Pero, además, comprarán patrulleros de última tecnologia, que vienen com GPS, o mapa de posicionamiento satelital.

GPS - apesar de não ser uma palavra, mas uma sigla de Global Positioning System, é usado como sendo um verbete. Poderia ser usado Sistema de Posicionamiento Global, o que alteraria a sigla para SPG.

\section{MATÉRIAS PUBLICITÁRIAS:}

1) Viví todas las notebooks em frávega.

NOTEBOOKS - a tradução para o espanhol seria bloc de notas, o que não corresponde ao sentido da frase, que se refere a um computador portátil. 


\subsubsection{OPINION}

Reportagem: NUEVAS Y PELIGROSAS BURBUJAS FINANCIERAS

1) ... lleva frecuentemente a processos de ajuste excesivos (overshooting) que generan recesiones y caídas em los precios de los activos superiores a las necesarias.

OVERSHOOTING - poderia ser traduzido como superación.

Reportagem: LAS MALAS SEÑALES QUE SE REPITEM

1) Copyright Clarín 2008.

COPYRIGHT - traduz-se como derecho de autor.

\subsubsection{ZONA}

Reportagem: EL PLAN DE RADARIZACIÓN, FRENADO POR UMA BATALLA DE EMPRESAS

1) ... el plan para radarizar los cielos argentinos vuelve a estar empantanado em una batalla entre empresas, lobbys internacionales e internas políticas.

LOBBYS - esta é mais uma palavra que é usada diretamente do inglês, com a mesma pronúncia e escrita.

2) Embajadores, lobbystas de empresas, peritos militares y funcionários discuten desde hace meses...

LOBBYSTAS - aqui já existe uma adaptação ao idioma. Lobbystas não existe no inglês. 


\subsubsection{SOCIEDAD}

Reportagem: EL FESTIVAL EVANGÉLICO CERRO EM EL OBELISCO ANTE 100.000 PERSONAS

1) Los adolescentes comenzaron a arrimarse cuando caía el sol para ver a las bandas de rock Cristiano.

ROCK - a tradução para o espanhol é roca, que obviamente não tem relação alguma com o contexto da frase.

2) Y más que remeras com La sonrisa de Palau, ayer había adolescentes hip hoperos com gorra al costado ...

HIP HOPEROS - mais uma vez, percebe-se a incorporação da palavra ao idioma local. Hip hoperos seriam pessoas adeptas do hip hop, mas essa expressão não existe no inglês.

3) Hasta el merchandising subió de precio.

MERCHANDISING - não foi encontrada tradução para a palavra.

O glossário para termos técnicos em inglês traduz como "propaganda, comercial". (ECONOGLOSS, 2008)

Reportagem: LA CIENCIA BUSCA EM EL CEREBRO DE LOS MÚSICOS LAS CLAVES DE LA CREATIVIDAD

1) Estudiaron a músicos de jazz para ver qué ocurría... JAZZ - não existe tradução para o espanhol. 
O dicionário de português explica como música norte-americana caracterizada por improvisação, ritmos sincopados, execução em conjunto contrapontístico e feições melódicas especiais, peculiares à interpretação individual de cada tocador. (MICHAELIS, 2007). A origem americana explica o uso do verbete.

\subsubsection{VIAJES}

Reportagem: BROADWAY: EL MUNDO DEL ESPETÁCULO

1) ... um musical que mezcla hip hop, salsa, rap y boleros.

HIP HOP - já usada em reportagem em português, também não tem tradução para o espanhol.

RAP - (Rytm and poetry) repete-se o ocorrido na palavra anterior. Assim como em “jazz", a origem explica o uso do anglicismo.

\subsubsection{IECO}

Reportagem: EL MOMENTO MÁS TEMIDO.

1) Las desventuras de Wall Street están llegando ahora a maisn street.

MAIN STREET - pode ser traduzido como calle principal.

Reportagem: "EL NACIÓN SERÁ UMA EMPRESA TESTIGO EM TODOS LOS MERCADOS"

1) Me gustaría impulsar el leasing, ver em detalle qué pasa com la factura conformada, que es un instrumento muy util em todo el mundo. 
LEASING - pode ser traduzida como arrendamiento.

Reportagem: LLEGA STARBUCKS: CÓMO SE PREPARA LA COMPETENCIA

1) Para su desembarco, La firma armo el joint-venture ...

JOINT-VENTURE - não tem tradução direta para o espanhol.

Segundo o Econogloss (2008) é um empreendimento conjunto. Uma das estratégias alternativas de entrada e operação em mercados externos. As quatro formas mais comuns: licença para uso de marcas e patentes, contrato de fabricação, contrato de administração e empreendimentos de propriedade conjunta.

2) Ya hay un grupo de diez managers que se está entrenando em las sucursales.

MANAGERS - pode ser traduzido como director, sem prejuízo de significado.

3) ... está muy detrás de McDonald's en fast-food.

FAST-FOOD - poderia ser usado o termo comida rápida.

4) ... Ilegaron a pensar en instalar self-service para bajar costos.

SELF-SERVICE - libre servicio. Pode ser melhor explicado como auto-atendimento.

5) ... si el lugar está de moda y es cool.

COOL - em espanhol traduz-se por fresco mas, na gíria da moda, quer dizer legal.

6) Con los precios de los commodities em alza, el valor promedio del kilo de café que se vende em los supermercados y almacenes subió...

COMMODITIES - em espanhol é traduzido como comodidades. 
Reportagem: MARCAS Y ENTRETENIMIENTO, UM NEGOCIO QUE AÚN NO DESPEGA

1) Por ahora, el advertainment da para presupuestos regionales.

ADVERTAINMENT - a palavra não foi encontrada nos dicionários de idiomas.

Segundo o Econogloss (2008) é um conceito que se propõe a fazer um mix entre publicidade e entretenimento.

2) Un nuevo paquete Premium de juegos interactivos...

PREMIUM -a tradução é prémio, premiación. Significa algo especial, para quem merece.

Reportagem: DETECTAR EMOCIONES, EL ÚLTIMO HALAZZGO DE LA ALTA TECNOLOGÍA

1) Cámaras sensoriales, dispositivos satelitales "inteligentes" y la minería de información (data mining, em inglés) ...

DATA MINING - o texto mostra a expressão em espanhol minería de información, acompanhada do termo em inglês.

2) De sus laboratórios surgieron, por ejemplo, el Pen Drive ...

PEN DRIVE - as palavras só foram encontradas separadas; uma vez juntas, são traduzidas pela mesma expressão. Pode ser entendido como unidade de disco em forma de caneta.

3) Precisamente ése es el objetivo del Business Intelligence ... 
BUSINESS INTELLIGENCE - essa expressão pode ser traduzida por negocio inteligente.

4) ... como las ventas y el stock.

STOCK - traduz-se por acciones, ou estoque, em português.

Reportagem: EMPLEADO COM INCENTIVOS VENDE MÁS Y ATIENDE MEJOR

1) Cada vez más se percibe su valor como estímulo para el personal.

PERSONAL - em espanhol também se usa personal. Em português traduz-se por pessoal.

2) ... mediante mistery shoppers, la recomendación de la marca que hacían los vendedores de distintos locales.

MISTERY SHOPPERS - traduz-se literalmente como vendedor de misterio.

3) Director de Business Risk Management

BUSINESS RISK MANAGEMENT - traduz-se como gestion de negocio de riesgos.

Reportagem: TECNOLOGÍA PARA CONGRESOS

1) Para salir adelante recurrió al hobby rentado de su padre.

HOBBY - a palavra não tem uma tradução.

O dicionário de língua portuguesa explica como atividade de recreio ou descanso praticada nas horas de lazer. (MICHAELIS, 2007)

Atividade de recreio ou descanso praticada nas horas de lazer. 
2) Además, tienen um start up.

START UP - literalmente se traduz como puesta en marcha. Na frase, a expressão significa "incentivo, algo mais".

3) Muy lejos de los comienzos, cuando la gente no entendia bien lo que hacían los hermanos y los confundían com disc jockers.

DISC JOCKERS - assim como discutido no texto em português, a expressão em inglês foi adotada para os outros idiomas.

\subsubsection{DESPORTES}

Reportagem: INDEPENDIENTE. TODO CAMBIA EM 10 MINUTOS

1) Pero el show continuó a pesar del dolor de muchos y de la malicia de unos pocos.

SHOW - traduzido como mostrar. A palavra é usada sem alterações em inglês, espanhol e português, utilizada para designar espetáculo.

Reportagem: MASCHERANO GOZÓ COM SU PRIMER GRITO EM LIVERPOOL

1) Ahora puedo concentrarme solamente en el fútbol.

FÚTBOL - assim como em português, em espanhol o verbete adaptou a escrita à pronúncia.

2) ... renunciará a su cargo en el club español.

CLUB - a palavra é usada com a mesma grafia nos dois idiomas, espanhol e inglês. 
Em português significa 1 Sociedade recreativa. 2 Grêmio. 3 Associação política. 4 Local em que se reúnem essas agremiações. (MICAELIS, 2007)

Reportagem: HAMILTON ARRANCÓ MEJOR

1) ...pero mientras giraba para regresar a los boxes, La bomba de nafta dejó detenida a su Ferrari.

BOXES - a palavra, que significa 1 caixa (de madeira, de papelão etc.), lata, caixote. 2 camarote. 3 cabina, cubículo, reservado. 4 abrigo pequeno, compartimento. 5 cocheira. 6 estande. (MICAELIS, 2007), tem a mesma grafia em português, inglês e espanhol.

Reportagem: BUENOS AIRES OBTUVO UN ÉXITO COM VALOR AGREGADO

1) ... a su buen juego de forwards debía agregarle mayor agresividad em ataque para vulnerar la buena defensa de Buenos Aires.

FORWARDS - a tradução literal é hacia adelante, mas o sentido na frase é ataque, avanço.

Reportagem: GALES SE CORONÓ COM UN CIERRE PERFECTO

1) ... fue juez de touch, se debió em gran parte al importante aporte de su mejor jugador ...

TOUCH - no inglês: contato ou, contacto (em espanhol)

Reportagem: AZUL SORPRENDIÓ Y PUSO UMA CUOTA DE SUSPENSO

1) Le puso suspenso Azul Vóley a una serie que no parecía tan pareja ... 
VÓLEY - a palavra ganhou acento e perdeu um "l", mas continua com a grafia e a pronúncia assemelhada a "volley", já discutido anteriormente.

\section{Reportagem: POR QUÉ SON INVENCIBLES}

1) ... en la historia de la mejor liga del planet básquet ...

PLANET BÁSQUET - traduz-se como planeta cesta, porém aqui a palavra básquet já recebeu alteração na grafia original do inglês basket.

2) Pero, por si esto fuese poco, tienen el mejor Record del Oeste.

RECORD - aqui o mesmo se repete quando a palavra apareceu no texto em português. A grafia segue igual ao inglês.

3) Por el Grand Prix de atletismo que se disputa em Mar Del Plata ...

GRAND PRIX - traduzido como Gran Premio.

4) Hóckey sobre patines.

HÓCKEY - o dicionário de inglês-espanhol não mostra outra opção de verbete.

O dicionário de português explica como sendo jogo disputado entre quadros de onze jogadores de cada lado, praticado em diversas variantes e cujo objetivo é introduzir em gols opostos uma pequena bola, empurrando-a ou batendo-a com um bastão recurvado, chamado estique. 


\subsection{EL MERCURIO}

\subsubsection{CAPA E CONTRACAPA}

1) Piñera afronta "test callejero" em el centro de Santiago.

TEST - mais uma vez aparece esta palavra, usada nos três idiomas pesquisados, sempre com o mesmo sentido e grafia.

2) El crack se dispara entre los adictos a las drogas em Chile

CRACK - a palavra não usa tradução para passear entre os idiomas.

O dicionário explica que é um narcótico produzido a partir da pasta-base da cocaína, bicarbonato de sódio e outras substâncias, apresentado em forma de pedras, as quais são fumadas em cachimbos improvisados. (MICHAELIS, 2007)

\section{3) Bodies, the exhibition}

BODIES, THE EXHIBITION - aqui a tradução seria Cuerpo, la exibición mas, como trata-se do nome de um evento, é comum utilizar-se do idioma inglês.

\subsubsection{INTERNACIONAL}

Reportagem: EL TEMIDO “TELÉFONO ROJO” SUENA EM LA CAMPAÑA

1) One, two, three, four ... Una niña de cabellos dorados cuenta inocentemente los pétalos de uma flor.

ONE, TWO, THREE, FOUR - Uno dos, tres, cuatro. 
2) Nine, eight, seven, six .. Al llegar a zero el brillante flash de una explosión nuclear cubre la vista y las nubes se tieñen de fuego. "iEsos son los riesgos!”, advierte uma alarmista voz en off del spot televisivo.

NINE, EIGHT, SEVEN, SIX .. ZERO - Nueve, ocho, siete, seis ... cero. Tanto aqui quanto nos numerais anteriores, cabe a utilização do inglês porque o texto refere-se a uma explosão nuclear autorizada pelo governo americano.

FLASH - esta palavra não usa tradução, apenas define-se como luminosidade intensa e instantânea (MICHAELIS, 2007)

OFF - traduz-se como apagado, mas o texto refere-se a fora de gravação.

SPOT - in situ ou, no local.

\subsubsection{VIDA SOCIAL}

Reportagem: "AFTER OFFICE", UMA INICIATIVA QUE MEZCLA TRABAJO Y AMISTAD

1) Gran aceptación tuvo la nueva forma de reunión social denominada "After Office".

AFTER OFFICE - no espanhol: después de la oficina, ou, de acordo com o texto, depois do trabalho.

2) Las reservas se pueden hacer incluso por internet.

INTERNET - palavra já discutida anteriormente. 
3) ... como olvidar la grabadora en el taxi cuando iban a reportear o despachar mal los temas a la hora de cierre.

TAXI - assim como na língua portuguesa, o espanhol também conserva o mesmo verbete do inglês.

Reportagem: ENTRE PCS TRAJO A CHILE "SENSATIN WHITE", UNA EXPERIENCIA INOLVIDABLE

1) "Sensation White" fue la fiesta más exitosa que há llegado a Chile.

SENSATION WHITE - Sensación blanca. Aqui também encontramos a nomeação de um evento, justificando o uso do anglicismo.

Reportagem: RESPUESTAS A DUDAS COTIDIANAS EN EL ARTE

1) ... sólo con marcar tiempos y hacer un show para ser aplaudido por la galera.

SHOW - palavra já integrante dos idiomas estudados.

\subsubsection{VIDA Y SALUD}

1) ... junto a música cela, concursos y una cata de shop ...

SHOP - traduz-se por tienda, ou loja.

2) ... a partir de las 19:00 funcionará um happy hour.

HAPPY HOUR - traduz-se como hora feliz, mas explica-se por horário, após o expediente de trabalho, em que as pessoas se reúnem em bares, clubes etc., para beber, comer e conversar. (MICHAELIS, 20047) 


\subsubsection{DESPORTES}

Reportagem: LOS CONSEJOS DE ISLA, GUTIÉRREZ Y TAPIA

1) ... hay factores de adaptación como el idioma o el estilo Del fútbol italiano que le pueden complicar su estadía.

FÚTBOL - novamente aparece a palavra fútbol, já discutida anteriormente.

Reportagem: LUTO EN EL FÚTBOL: MUERE ALFREDO “TORPEDO” NÚÑEZ

1) ... cuando terminaba un amistoso de baby.

BABY - bebé. Aqui usou-se com a intenção de "infantil".

\subsubsection{ARTES Y LETRAS}

Reportagem: IAN Mc EWAN: "MADAME BOVARY HÁ MUERTO"

1) ... en la Universidad descubrí el jazz.

JAZZ - mais vez aparece o estilo musical importado dos EUA.

Reportagem: EL PRIMER LIBRO DE BOB DYLAN

1) ... el chico country que admiraba a Woody Guthrie e interpretaba canciones folk...

COUNTRY - na frase, tem o sentido de interior, campo, região rural.

FOLK - popular.

2) ... a la manera de un Rimbaud en tiempo de rock.

ROCK - mais um estilo musical. 
3) ... a los ídolos de la fiction.

FICTION - poderia ser usada a palavra ficción.

4) de un rockstar devastado por una sobredosis en el cuarto de un hotel ... ROCKSTAR - estrela del rock. Cantor de rock.

HOTEL - assim como na língua portuguesa, o espanhol também herdou a mesma grafia desta palavra.

5) ... ausência de feeling con el público.

FEELING - pode ser traduzido como sentimento. Na frase, caberia melhor a palavra empatía.

Reportagem: FOLLET BIEN VALE UM DESAYUNO

1) Se exhibió además um trailer que mostraba la formidable campaña de marketing

TRAILER - a tradução encontrada foi remolque (reboque), o que não corresponde ao valor da frase, que significa trechos de filmes. (MICHAELIS, 2007)

MARKETING - traduzida como comercialización para o espanhol.

\subsubsection{ECONOMYA Y NEGOCIOS}

Reportagem: CHILE 2010: LOS RICOS POBRES

1) En 2008 terminaremos de constatar que el alza de precios de los commodities metálicos, en particular el cobre, está aqui para quedarse ... 
COMMODITIES - aqui uma palavra presente em todos os jornais pesquisados, mostrando que a economia é globalizada nos produtos e nas palavras.

Reportagem: CULTIVO DE PERLAS MABE

1) ... a cambio del pago de um royalty ...

ROYALTY - para o espanhol traduz-se como regalías. O dicionário de língua portuguesa explica como comissão entre proprietário e usuário de uma patente industrial ou marca de fantasia, ou entre o editor e autor de um livro. (MICHAELIS, 2007)

Reportagem: EL MERCURIO Y IGM ABREN INSCRIPCIONES PARA FORMACIÓN FLEXIBLE

1) ... tanto los sócios del club de lectores como los alumnos ...

CLUB - aqui aparece mais um verbete já discutido anteriormente.

\subsubsection{NACIONAL}

Reportagem: PÉRDIDA DE DOCUMENTOS EXTRANJEROS

1) ... más importante empresa de courier del país...

COURIER - em espanhol, correo.

Reportagem: CARABINEROS PONDRÁ A SUS EFECTIVOS A TRABAJAR EN UN TRATO MÁS DIURECTO CON LA COMUNIDAD

1) Pero ahora estamos trabajando en el software.

SOFTWARE - usada sem tradução ou adaptação em vários idiomas. 
Reportagem: OBSESIONES QUE DESNUDAN LAS CINCO DÉCADAS DE MADONNA

1) referente ochentero a sex symbol cincuenterón.

SEX SYMBOL - símbolo sexual, em espanhol. O uso da expressão em inglês dá mais charme à frase.

2) ... con uma banda marcial em clave pop y hip-hop ...

POP - novamente aparecem os estilos musicais.

HIP HOP - importados dos EUA, continuam sendo chamados pelos nomes que lá receberam.

3) ... como el más sexy del Mundial de Francia.

SEXY - não encontrou-se tradução. Utiliza-se a mesma grafia em inglês, espanhol e na língua portuguesa.

\subsubsection{REPORTAJES}

Reportagem: GOBIERNO ACOGE PROPUESTAS PARA "OXIGENAR LA POLÍTICA"

1) El think tank de derecha les entrego una minuta ...

THINK TANK - literalmente é traduzido como tanque de pensar. É usado no texto com o sentido de grupo de decisão. 
1) El rating sube como espuma.

RATING - traduz-se como classificación. É um sinônimo de ranking.

Reportagem: "¡POR FAVOR, PAREMOS ESTO! VAMOS POR UNA PENDEINTE MUY PELIGROSA"

1) .. que le recetó para el déficit atencional?

DÉFICIT - mais uma vez surge esta palavra já discutida nos jornais anteriores.

Reportagem: LAS DUDAS DE LA UDI

1) Por qué un ejecutivo top y no um político ...

TOP - a tradução para o espanhol é superior, mas o sentido no texto refere-se a importante, seleto.

Reportagem: TRAVESÍA SIN BLINDAJE

1) ... almuerza um sandwich ...

SANDWICH - conjunto de duas fatias de pão, entre as quais se põe outra de carne, presunto, queijo, salame etc. (MICHAELIS, 2007), recebe a mesma escrita em inglês e espanhol.

Reportagem: DESAFÍO NACIONAL

1) ... con bastantes poblemas, la del lobby.

LOBBY - presente em todos os jornais pesquisados, mostra que a política também é semelhante nos diversos países.

2) ... su agenda está en la página web ... 
WEB - novamente aparece esta expressão, usada mundialmente sem adaptações ou traduções.

3) Lamentablemente, la ley se aprobó con un registro de lobbistas ...

LOBBISTAS - mais uma vez aparece esta palavra, derivada de lobby e criada nos idiomas espanhol e português.

\subsubsection{DOMINGO}

Reportagem: BUZIOS ÍNTIMO

1) ... siempre bullibiosa e hiper turística Buzios.

HIPER - assim como na língua portuguesa, o espanhol também já incorporou o verbete "hiper" como designação para aumentar, reforçar ou destacar a importância de algo.

2) ... disfrutan en el lounge bar de la pousada.

LOUNGE BAR - ou salón bar. Refere-se ao estabelecimento que tem bar e salão para dança.

Reportagem: LA GRAN BARRERA DE BELICE

1) ... el único all inclusive de la Gran Barrera.

ALL INCLUSIVE - ou, no espanhol, todo incluído. Refere-se ao hotel que tem vários serviços incluídos na diária.

2) Robinson Crusoe style. 
STYLE - aqui poderia ser usada a palavra estilo.

3) ... cheesies y salsichas...

CHESSIES - é utilizada a mesma palavra nos idiomas inglês e espanhol para designar queijo.

4) ... gringos homeless ...

HOMELESS - em espanhol poderia ser usado sin hogar. Na língua portuguesa: desabrigados.

5) ... face to face, tiburones toros, martillo.

FACE TO FACE - traduz-se para o espanhol como cara a cara.

\subsection{ANALISANDO E DISCUTINDO OS RESULTADOS}

Foram pesquisadas palavras do idioma inglês nos textos dos jornais selecionados, de língua portuguesa e espanhola. Não foram considerados os nomes próprios, de pessoas, lugares, títulos de livros, filmes, músicas ou espetáculos.

As palavras foram citadas com as frases em que estavam inseridas visando melhor compreender o sentido em que foram empregadas, já que a análise de palavras soltas pode levar a interpretações diversas.

Observe-se a tabela abaixo: 
TABELA - Palavras pesquisadas nos jornais escolhidos

\begin{tabular}{|c|c|c|c|c|}
\hline & PALAVRAS PESQUISADAS & $\begin{array}{l}\text { FOLHA DE } \\
\text { SÃO PAULO }\end{array}$ & CLARÍN & $\begin{array}{c}\text { EL } \\
\text { MERCURIO }\end{array}$ \\
\hline 1 & Advertainment & & $\mathbf{X}$ & \\
\hline 2 & After office & & & $\mathbf{X}$ \\
\hline 3 & All inclusive & & & $\mathbf{X}$ \\
\hline 4 & American way of life & $\mathbf{X}$ & & \\
\hline 5 & Baby & & & $\mathbf{X}$ \\
\hline 6 & Bar & $\mathbf{X}$ & & \\
\hline 7 & Bodies, the exhibition & & & $\mathbf{X}$ \\
\hline 8 & Boom & $\mathbf{X}$ & & \\
\hline 9 & Boxes & & $\mathbf{x}$ & \\
\hline 10 & Business intelligence & & $\mathbf{X}$ & \\
\hline 11 & Business risk management & & $\mathbf{X}$ & \\
\hline 12 & Cartum & $\mathbf{X}$ & & \\
\hline 13 & Cds & $\mathbf{X}$ & & \\
\hline 14 & Charge & $\mathbf{x}$ & & \\
\hline 15 & Chef & $\mathbf{X}$ & & \\
\hline 16 & Chessies & & & $\mathbf{X}$ \\
\hline 17 & Clown & & $\mathbf{X}$ & \\
\hline 18 & Club & & $\mathbf{X}$ & $\mathbf{X}$ \\
\hline 19 & Commodities & $\mathbf{X}$ & $\mathbf{X}$ & $\mathbf{X}$ \\
\hline 20 & Cool & & $\mathbf{X}$ & \\
\hline 21 & Copyright & & $\mathbf{x}$ & \\
\hline 22 & Cosplay & $\mathbf{X}$ & & \\
\hline 23 & Country & & & $\mathbf{X}$ \\
\hline 24 & Courier & & & $\mathbf{X}$ \\
\hline 25 & Cover & $\mathbf{X}$ & & \\
\hline 26 & Crack & & & $\mathbf{X}$ \\
\hline 27 & Data mining & & & \\
\hline 28 & Deficit & $\mathbf{X}$ & & $\mathbf{X}$ \\
\hline 29 & Diésel & & $\mathbf{X}$ & \\
\hline 30 & Disc jockers & $\mathbf{X}$ & $\mathbf{X}$ & \\
\hline 31 & Doping & $\mathbf{X}$ & & \\
\hline 32 & E-mail & $\mathbf{x}$ & & \\
\hline 33 & Extra & $\mathbf{X}$ & & \\
\hline 34 & Face to face & & & $\mathbf{X}$ \\
\hline 35 & Fallow up & & $\mathbf{X}$ & \\
\hline 36 & Fast-food & & $\mathbf{X}$ & \\
\hline 37 & Fax & & $\mathbf{x}$ & \\
\hline 38 & Feeling & & & $\mathbf{X}$ \\
\hline 39 & Fiction & & & $\mathbf{X}$ \\
\hline 40 & Flash & & & $\mathbf{X}$ \\
\hline 41 & Flyers & $\mathbf{X}$ & & \\
\hline 42 & Folk & & & $\mathbf{X}$ \\
\hline 43 & Fowards & & $\mathbf{X}$ & \\
\hline 44 & Fútbol & $\mathbf{X}$ & $\ddot{X}$ & $\mathbf{X}$ \\
\hline 45 & Gay & $\mathbf{x}$ & & \\
\hline 46 & GPS & & $\mathbf{X}$ & \\
\hline 47 & Grand prix & & $\mathbf{x}$ & \\
\hline 48 & Hackers & & $\mathbf{X}$ & \\
\hline 49 & Happy hour & & & $\mathbf{X}$ \\
\hline 50 & Hip hop & $\mathbf{X}$ & $\mathbf{X}$ & $\mathbf{x}$ \\
\hline 51 & Hip hoperos & & $\mathbf{X}$ & \\
\hline 52 & Hiper & & & $\mathbf{X}$ \\
\hline 53 & Hobby & & $\mathbf{x}$ & \\
\hline 54 & Hóckey & & $\mathbf{X}$ & \\
\hline
\end{tabular}




\begin{tabular}{|c|c|c|c|c|}
\hline 55 & Homeless & & & $\mathbf{X}$ \\
\hline 56 & Hotel & $\mathbf{X}$ & $\mathbf{X}$ & $\mathbf{X}$ \\
\hline 57 & Hotspots & $\mathbf{X}$ & & \\
\hline 58 & Internet & $\mathbf{X}$ & $\mathbf{X}$ & $\mathbf{X}$ \\
\hline 59 & Jazz & & $\mathbf{X}$ & $\mathbf{x}$ \\
\hline 60 & Jet ski & $\mathbf{X}$ & & \\
\hline 61 & Joint-venture & & $\mathbf{X}$ & \\
\hline 62 & Kit & $\mathbf{X}$ & & \\
\hline 63 & Know how & $\mathbf{X}$ & & \\
\hline 64 & Leasing & & $\mathbf{X}$ & \\
\hline 65 & Lobbistas & & $\mathbf{X}$ & $\mathbf{x}$ \\
\hline 66 & Lobby & $\mathbf{X}$ & $\mathbf{X}$ & $\mathbf{X}$ \\
\hline 67 & Lounge bar & & & $\mathbf{x}$ \\
\hline 68 & Main street & & $\mathbf{X}$ & \\
\hline 69 & Managers & & $\mathbf{X}$ & \\
\hline 70 & Marketing & $\mathbf{X}$ & & $\mathbf{X}$ \\
\hline 71 & Marqueteiros & $\mathbf{X}$ & & \\
\hline 72 & Merchandising & & $\mathbf{X}$ & \\
\hline 73 & Mistery shoppers & & $\mathbf{X}$ & \\
\hline 74 & Mountain-bike & $\mathbf{X}$ & & \\
\hline 75 & Music & $\mathbf{X}$ & & \\
\hline 76 & Nerd & $\mathbf{X}$ & & \\
\hline 77 & Nine, eight, seven, six .. Zero & & & $\mathbf{X}$ \\
\hline 78 & Notebooks & & $\mathbf{X}$ & \\
\hline 79 & Off & $\mathbf{X}$ & & $\mathbf{x}$ \\
\hline 80 & Ombudsman & $\mathbf{X}$ & & \\
\hline 81 & One, two, three, four & & & $\mathbf{x}$ \\
\hline 82 & On-line & $\mathbf{X}$ & & \\
\hline 83 & Overshooting & & $\mathbf{X}$ & \\
\hline 84 & Pen drive & & $\mathbf{X}$ & \\
\hline 85 & Pênalti & $\mathbf{X}$ & & \\
\hline 86 & Performers & $\mathbf{X}$ & & \\
\hline 87 & Personal & & $\mathbf{X}$ & \\
\hline 88 & Planet básquet & & $\mathbf{X}$ & \\
\hline 89 & Pocket show & $\mathbf{X}$ & & \\
\hline 90 & Pônei & $\mathbf{X}$ & & \\
\hline 91 & Pop & $\mathbf{X}$ & & $x$ \\
\hline 92 & Premium & & $\mathbf{X}$ & \\
\hline 93 & Rafting & $\mathbf{X}$ & & \\
\hline 94 & Ranking & $\mathbf{X}$ & & \\
\hline 95 & Rap & & $\mathbf{X}$ & \\
\hline 96 & Rapel & $\mathbf{X}$ & & \\
\hline 97 & Rating & & & $\mathbf{x}$ \\
\hline 98 & Reality show & $\mathbf{X}$ & & \\
\hline 99 & Record & $\mathbf{X}$ & $\mathbf{X}$ & \\
\hline 100 & Rock & $\mathbf{X}$ & $\mathbf{X}$ & $\mathbf{X}$ \\
\hline 101 & Rockstar & & & $\mathbf{x}$ \\
\hline 102 & Royalty & & & $\mathbf{X}$ \\
\hline 103 & Rugby & & $\mathbf{X}$ & \\
\hline 104 & Sandwich & & & $\mathbf{X}$ \\
\hline 105 & Self-service & & $\mathbf{X}$ & \\
\hline 106 & Sensation white & & & $\mathbf{X}$ \\
\hline 107 & Sex symbol & & & $\mathbf{X}$ \\
\hline 108 & Sexy & $\mathbf{X}$ & & $\mathbf{X}$ \\
\hline 109 & Shop & & & $\mathbf{X}$ \\
\hline 110 & Shopping & $\mathbf{X}$ & & \\
\hline 111 & Short & $\mathbf{X}$ & & \\
\hline 112 & Show & & $\mathbf{X}$ & $\mathbf{X}$ \\
\hline 113 & Sites & $\mathbf{X}$ & & \\
\hline 114 & Slogan & $\mathbf{X}$ & & \\
\hline
\end{tabular}




\begin{tabular}{|c|c|c|c|c|}
\hline 115 & Software & $\mathbf{X}$ & & $\bar{x}$ \\
\hline 116 & Spot & & & $\mathbf{X}$ \\
\hline 117 & Standard & $\mathbf{X}$ & & \\
\hline 118 & Start up & & $\mathbf{X}$ & \\
\hline 119 & Status & $\mathbf{X}$ & & \\
\hline 120 & Stock & & $\mathbf{X}$ & \\
\hline 121 & Style & & & $\mathbf{x}$ \\
\hline 122 & Super & $\mathbf{X}$ & & \\
\hline 123 & Surfista & $\mathbf{X}$ & & \\
\hline 124 & Taxi - & & & $\mathbf{X}$ \\
\hline 125 & Tênis & $\mathbf{X}$ & & \\
\hline 126 & Test & & $\mathbf{X}$ & $\mathbf{X}$ \\
\hline 127 & Test-drive & $\mathbf{X}$ & & \\
\hline 128 & Think tank & & & $\mathbf{X}$ \\
\hline 129 & Thriller & $\mathbf{X}$ & & \\
\hline 130 & Top & & & $\mathbf{X}$ \\
\hline 131 & Touch & & $\mathbf{X}$ & \\
\hline 132 & Trailer & & & $\mathbf{X}$ \\
\hline 133 & Triple play & $\mathbf{X}$ & & \\
\hline 134 & Underground & $\mathbf{X}$ & & \\
\hline 135 & Videotape & $\mathbf{X}$ & & \\
\hline 136 & VIPs & $\mathbf{X}$ & & \\
\hline 137 & Vôlei & $\mathbf{X}$ & $\mathbf{X}$ & \\
\hline 138 & Web & & $\mathbf{X}$ & $\mathbf{X}$ \\
\hline 139 & Windsurf & $\mathbf{X}$ & & \\
\hline & TOTAL & 64 & 51 & 51 \\
\hline
\end{tabular}

Foram 139 palavras pesquisadas. Destas 63 estavam no jornal Folha de São Paulo e 51 palavras em cada um dos jornais de língua espanhol. Clarín e El Mercurio. Ainda se percebe que 15 palavras apareceram em dois jornais diferentes e 6 palavras foram destacadas nos três jornais pesquisados, sendo elas: commodities, hip-hop, hotel, internet, lobby e rock.

Separando-se por área, temos:

TABELA - Contribuição das áreas para a introdução dos anglicismos

\begin{tabular}{llc} 
ÁREA & PALAVRAS & TOTAL \\
\hline ESPORTE & $\begin{array}{l}\text { Boxes, Doping, Fútbol, Grand prix, Hóckey, Jet ski, Mountain- } \\
\text { bike, Pênalti, Planet básquet, Rafting, Rapel, Rugby, Surfista, } \\
\text { Tennis, Vôlei e Windsurf }\end{array}$ & $\mathbf{1 6}$ \\
\hline $\begin{array}{l}\text { CIÊNCIA E } \\
\text { TECNOLOGIA }\end{array}$ & $\begin{array}{l}\text { CDs, E-mail, Fax, GPS, Hackers, Hotspots, Internet, Nerd, } \\
\text { Notebooks, On-line, Pen drive, Sites, Software, Videotape, } \\
\text { Web. }\end{array}$ & $\mathbf{1 5}$ \\
MÚSICA E ARTE & $\begin{array}{l}\text { Cartum, Charge, Cosplay, Cover, Disc jockers, Flyers, Folk, Hip } \\
\text { hop, Hip hoperos, Jazz, Music, Performers, Pop, Rap, Rock, }\end{array}$ & $\mathbf{1 7}$ \\
Rockstar, Underground \\
ECONOMIA E & $\begin{array}{l}\text { Advertainment, After office, Business intelligence, Business risk } \\
\text { management, Commodities, Copyright, Data mining, Fallow up, }\end{array}$ & $\mathbf{2 8}$ \\
\hline
\end{tabular}


Joint-venture, Kit, Know how, Leasing, Lobbistas, Lobby, Main

street, Managers, Marketing, Marqueteiros, Merchandising,

Mistery shoppers, Ombudsman, Overshooting, Royalty, Selfservice, Shop, Shopping, Slogan.

\section{ALIEMENTAÇÃO}

E DIVERSÃO

All inclusive, American way of life, Bar, Bodies, the exhibition,

Chef, Chessies, Club, Fast-food, Happy hour, Hobby, Hotel,

Lounge bar, Pocket show, Reality show, Sandwich, Sensation white, Show, Thriller, Trailer.

Aqui se observa algumas áreas que são grandes contribuintes de anglicismos para os idiomas espanhol e português. O esporte mostrou-se uma surpresa, trazendo mais palavras que a área de ciência e tecnologia, citada como grande importadora de verbetes.

Economia e negócios, ao contrário, confirmou a expectativa, sendo a área onde mais anglicismos apareceram.

Percebe-se ainda que algumas palavras já receberam adaptação ao idioma receptor, enquanto outras vivem harmonicamente conservando a grafia original.

TABELA - Palavras que conservam a escrita original e palavras adaptadas no novo idioma

\section{ORIGINAL}

Bar, Boxes, Charge, Chef, Chessies, Club, Commodities, Copyright, Country, Cover, Crack, Data mining, Deficit, Doping, E-mail, Extra, Fast-food, Fax, Feeling, Flash, Gay, Grand prix, Hackers, Happy hour, Hip hop, Hiper, Hobby, Hockey, Hotel, Internet, Jazz, Jet ski, Jointventure, Kit, Know how, Leasing, Lobby, Lounge bar, Managers, Marketing, Merchandising, Mountain-bike, Music, Nerd, Notebooks, Ombudsman, On-line, Overshooting, Pen drive, Personal, Pop, Premium, Rafting, Ranking, Rap, Rapel, Rating, Reality show, Record, Rock, Royalty, Rugby, Self-service, Sexy, Shopping, Short, Sites, Slogan, Software, Super, Test-drive, Top, Trailer, Videotape, Web, Windsurf.

\section{ADAPTADA}

Cartum, Diésel (acentuada em espanhol), Fútbol, Hip hoperos, Lobbistas, Marqueteiros, Pênalti, Pônei, Surfista, Táxi (em português ganhou acento), Tênis, Vôlei 
VIP - very important personal

CD - compact disc

GPS - Global Position System

DJ - disc jokey

Com a verificação de 139 anglicismos, alguns deles aparecendo em mais de um jornal, ou seja, mais de um país, reconhece-se a importância dos anglicismos na criação e evolução de outros idiomas.

A globalização, com a troca de mercadorias, turismo, culturas, artes, a popularização da internet, a velocidade com que as informações cruzam o globo, facilitam também o transporte das palavras, que trazem consigo também costumes que, assim como os verbetes, são adaptados à realidade das pessoas que os recebem.

\subsection{JORNAIS ON LINE}

Agora se apresenta a coleta de anglicismos nas versões on-line dos jornais "Folha on Line" (Folha de São Paulo), "EMOL" (El Mercurio on line) e "Clarín on line".

\subsubsection{FOLHA ON-LINE}

COLUNAS

Reportagem: Depois de abrir balcão, Lula tenta frear fisiologia

1) Na crise do mensalão, o presidente Luiz Inácio Lula da Silva temeu que prosperasse na Câmara dos Deputados um processo de impeachment. 
IMPEACHMENT - no dicionário de língua portuguesa, é o processo político-criminal que se instaura contra o presidente da República, qualquer governador, ministro do Supremo Tribunal ou procurador-geral da República, com o fim de impor-Ihe a pena de destituição do cargo, por delito de responsabilidade resultante da infração de deveres funcionais em prejuízo dos interesses da Nação.

O dicionário de inglês diz que é o impedimento legal de exercer mandato, de ocupar cargo.

Reportagem: Sem Marcelo, Globo teme queda de "BBB" no lbope

1) Não é por acaso que a direção do "BBB" colocou famosos como Deborah Secco e Cláudia Leitte no reality show.

BBB Big Brother Brasil - traduzido como "Grande Irmão", é um programa com formato importado, mas que optou em apresentar-se com nome em inglês. Aqui se percebe que a principal importação é cultural.

REALITY SHOW - pode ser traduzido como exibição da realidade. Na prática é uma modalidade de programa que mostra o comportamento das pessoas em situações reais, geralmente contando com câmeras que filmam 24 horas por dia.

\section{Reportagem: Sem flashes}

1) O governador de Minas Gerais, que recentemente teve um affair com a Miss Brasil, Natália Guimarães, está mais reservado em relação à vida pessoal.

FLASH - a tradução do inglês diz que é um lampejo, clarão ou brilho repentino e passageiro, sinal luminoso, jato de luz, relâmpago. 
O dicionário de língua portuguesa trata como lâmpada elétrica de luminosidade intensa e instantânea que possibilita tirarem-se fotografias em lugares de iluminação insuficiente.

AFFAIR - esta palavra, na verdade não é um anglicismo, mas é um estrangeirismo. Importada da França, affair refere-se a "namoro casual".

MISS - a tradução literal seria "senhorita", mas a palavra refere-se a uma participante de um concurso de beleza.

Reportagem: Tudo combinado

1) A atriz Myriam Martin, que faz a sensual Rosinha do "Zorra Total" (Globo), chamou um fotógrafo amigo para "flagrá-la" fazendo topless, no Rio.

TOPLESS - a tradução do inglês é a mesma apresentada pelo dicionário de língua portuguesa: Diz-se da roupa de banho feminina que deixa o corpo nu da cintura para cima.

Reportagem: Passaporte para o aborrecimento

1) Ao chegar no local de atendimento ontem, dentro de um shopping, com toda a documentação e meia hora antes do horário, surpresa:

PASSAPORTE - do inglês, passport, que traz exatamente a tradução "passaporte". Na língua portuguesa explica-se como Documento de licença pelo qual a autoridade pública permite que alguém, devidamente identificado, tenha livre trânsito dentro do próprio país ou em país estrangeiro. 
SHOPPING - já explicada anteriormente, esta palavra costuma ser utilizada como referência a "centro de compras". A tradução literal seria "comprando". O curioso é que nos Estados Unidos a palavra usada para o equivalente a shopping é "Mall".

2) "OK", respondi resignado e me encaminhei bovinamente para o banco ao lado.

OK - este verbete acabou virando palavra, com o sentido de certo, correto, mas é, na realidade, uma sigla. Não foi encontrada em nenhum dos dicionários de idiomas.

Existem diversas explicações para o significado desta sigla. Uma delas diz que a expressão OK surgiu durante a Guerra da Secessão. Quando as tropas voltavam para o quartel após uma batalha sem nenhum tipo de baixa, escreviam abreviadamente a seguinte expressão: "O Killed" (zero mortos). Disso, surgiu a expressão que se usa para indicar que está tudo bem.

3) Inclusive ofereci a ele meu e-mail...

E-MAIL - palavra já estudada anteriormente, aparece novamente aqui.

4) Para quem tiver curiosidade, no link abaixo constam todos os salários da administração pública federal.

LINK - em português tem-se "Participação ao vivo de um repórter ou alguém que não se encontra na própria estação de TV (na rua, por exemplo): A apresentadora do programa pediu um link para que os visitantes da feira pudessem fazer perguntas ao entrevistado."

O dicionário de inglês aponta a tradução como: 1 argola, elo. 2 conexão. 3 Typo gr medida de 7,92 polegadas. 4 articulação. 5 ligação, vínculo. encadear, unir, ligar. 
No texto, o verbete é usado com o sentido de conexão.

DINHEIRO

Reportagem: Minério de ferro deve render $61 \%$ mais

1) A perspectiva de mais um período de demanda aquecida desenha 2008 como um novo ano de quebra de recordes das commodities minerais.

COMMODITIES - palavra sempre presente nas notícias de economia. Significa mercadorias, no sentido de produtos primários ou básicos, como café, algodão, açúcar, trigo e minérios etc. (Econogloss, 2008)

2) O déficit de US\$1,150 bilhão praticamente repete o desempenho de 2007. DÉFICIT - palavra já estudada anteriormente. Poderia ser utilizada deficiência.

3) Para o níquel, a previsão é superávit de US $\$ 420$ milhões.

SUPERÁVIT - o dicionário de inglês não traz esta palavra. Em português significa "O excesso da receita sobre a despesa num orçamento."

4) Prova disso são os negócios à vista, que também registram sucessivos recordes. RECORDES - palavra já estudada.

\section{CINEMA}

Reportagem: Mostra em São Paulo apresenta 20 filmes gratuitos

1) Os filmes serão exibidos em formatos DVD. 
DVD - este verbete é, na verdade, uma sigla. Significa Digital Video Disk. Não foi encontrado em nenhum dos dicionários.

\section{DINHEIRO}

Reportagem: Banda larga puxa TV por assinatura, que cresce 13\% em 2007

1) $O$ acesso à internet de alta velocidade mais uma vez puxou o crescimento da TV paga no país.

INTERNET - palavra sempre presente nos jornais pesquisados.

2) Na esteira do "triple play", o Net Fone via Embratel teve expansão de 212\%.

TRIPLE PLAY - palavra já estudada. No texto, refere-se a telefone, internet e TV por assinatura.

3) A Sky, segunda maior empresa de TV paga do país, pediu à Anatel que recomendasse ao Cade (Conselho Administrativo de Defesa Econômica) a rejeição da aquisição da TVA - terceira no ranking- pela Telefônica.

SKY - em inglês, a palavra significa céu. No texto, refere-se a uma empresa de televisão por assinatura.

RANKING - verbete já estudado. Significa classificação.

\section{ILUSTRADA}

Reportagem: Lenny Kravitz volta ao Brasil no mês que vem

1) O cantor Lenny Kravitz se apresentará em São Paulo em dois shows.

SHOW - palavra estudada nas versões escritas dos jornais. É usada sem alterações. 
2) Os ingressos variam de $R \$ 100$ (platéia superior 3) a $R \$ 400$ (camarote setor 1) e estão à venda a partir deste domingo (16) na bilheteria do evento ou pelo site.

SITE - esta palavra aparece sempre que o texto se refere à Internet. É usada sem alterações nos idiomas português e espanhol.

Reportagem: Search marketing tem que ser integrado às campanhas publicitárias 1) No Brasil a maioria das pessoas são impactadas por uma marca pela primeiras vez através de mídias offline, como TV, rádio e mídia impressa.

SEARCH MARKETING - como esperado, não aparece no dicionário de língua portuguesa. Em inglês pode ser traduzido como "pesquisa mercadológica".

OFFLINE - não aparece no dicionário de português. Em inglês significa fora de linha: o que não se acha ligado a um computador.

2) ...quem sabe mais detalhes da promoção de desconto de fim de semana ou sobre como agendar um test-drive.

TEST-DRIVE - palavra já estudada, refere-se a teste de produtos novos.

4) Então, quais são as implicações para marketeiros?

MARKETEIROS - palavra aportuguesada, não aparece no dicionário em inglês, mas em língua portuguesa significa pessoa ou profissional do marketing (é interessante que um anglicismo é usado para explicar outro). 
5) Para obter alguns dos indicadores de performance de sua campanha de search marketing...

MARKETING - palavra estudada, refere-se a mercado.

6) rankings, tráfego proveniente de sites de busca...

RANKINGS - o dicionário de inglês explica como 1 execução, efetuação. 2 cumprimento, desempenho. 3 façanha, proeza. 4 representação, artística, espetáculo. 5 atuação (de artista, atleta etc.). 6 capacidade de trabalho mecânico, rendimento.

O dicionário de língua portuguesa traz como significado: 1 Realização, feito, façanha. 2 Atuação, desempenho.

8) A criação e conteúdo (slogan, detalhes da promoção, folhetos, diálogo dos comerciais etc)

SLOGAN - palavra já estudada.

9) Uma outra área, que já é uma realidade, é a participação e monitoramento da campanha em comunidades, blogs e fóruns e todos os outros sites.

BLOGS - palavra não encontrada em nenhum dos dicionários pesquisados. Referese a uma página da Web, cuja estrutura permite a atualização rápida a partir de acréscimos de tamanho variável, chamados artigos, ou "posts"). Estes são organizados cronologicamente de forma inversa (como um diário) e costumam abordar a temática do blog, e podem ser escritos por um número variável de pessoas, de acordo com a política do blog.

Também pode ser chamado de caderno digital. 
Reportagem: "O grande desafio é educar"

1) ... prestigiada revista italiana de arquitetura e design.

DESIGN - em inglês é traduzido como 1 projeto, intento, esquema, plano, escopo, fim, motivo, enredo, tenção. 2 desenho, bosquejo, esboço, debuxo, delineação, risco, modelo. 3 invenção artística, arranjamento, arte de desenho. 1 projetar, planejar, ter em mira, propor-se, ter intenção. 2 designar, destinar, assinar. 3 desenhar, traçar, debuxar, esboçar, delinear, bosquejar.

O dicionário de língua portuguesa explica como 1 Concepção de um projeto ou modelo; planejamento. 20 produto deste planejamento.

MUNDO

Reportagem: Gallup já traz McCain à frente de Obama: 47\% a 44\%

1) Dá-se às pesquisas que o Gallup vem realizando o nome de "tracking".

TRACKING - curiosamente, esta palavra não aparece no dicionário de inglês. O dicionário de língua portuguesa explica como 1 Alinhamento correto de uma cabeça de leitura e da fita num videocassete ou unidade de fita. 2 Degradação da imagem de um clipe de vídeo, causada por ação que se desenvolve rápido demais, impedindo que a câmera a capture de forma precisa.

\section{COTIDIANO}

Reportagem: Três homens são presos fardados de policiais

1) Os acusados estavam em um bar.

BAR - palavra estudada e usada sem alterações nos três idiomas. 
Reportagem: China bloqueia Youtube após aparição de vídeos do Tibete

1) O governo chinês aparentemente bloqueou o site de vídeos Youtube.

BLOQUEIA - esta palavra é aportuguesada, deriva-se da palavra click, que significa 1 tique-taque, estalido, estalo, pancadinha. 2 trinco, tranqueta, aldrava. 3 lingüeta, trava. 4 clique: estalido feito com a língua. 1 fazer tique-taque, dar estalidos. 2 estalar, tinir. 3 bater, fechar-se (fechadura).

BLOQUEOU - idem à anterior.

\section{ESPORTES}

Reportagem: Lewis Hamilton comemora vitória no GP da Austrália

1) ... acabou desclassificado por ter reabastecido seu carro quando os boxes estavam fechados.

BOXES - palavra já estudada.

\subsubsection{EMOL - EL MERCÚRIO ON LINE}

EDITORIAL

\section{GLOBAL}

Reportagem: Tony Blair llama a la "acción colectiva" global para proteger clima

1) Un grupo de expertos en clima, bajo su dirección política, publicará en junio un informe preliminar...

EXPERTOS - deriva-se do inglês "expert", que significa "perito, técnico, especialista." 
O dicionário de espanhol explica como " experiente, perito", mostrando que têm a mesma finalidade.

2) Previamente, en su página web, Blair sostuvo que todos los países deberían comprometerse a reducir las emisiones globales de dióxido de carbono.

WEB - não existe tradução para o espanhol.

Reportagem: Tres aerolíneas anuncian planes para realizar vuelo de demostración de biocombustible

1) CFM es un joint venture a partes iguales entre General Electric Company y Snecma (Grupo SAFRAN).

JOIN VENTURE - não tem tradução para o espanhol ou o português.

\section{CIENCIA Y TECNOLOGÍA}

Reportagem: Downgrade HP Slim 3110la

1) Una gran pantalla, un compacto diseño y prestaciones para los usuarios domesticos que descargan cosas desde diversos medios e Internet (y nunca respaldan).

INTERNET - palavra sempre presente e estudada.

2) Aqui encontran los drives usando como guia su placa madre, una Asus M2N61.

DRIVES - a tradução para o espanhol é "conducir", referindo-se a dirigir.

Em espanhol refere-se a "Parte de um computador que opera um disco ou fita; unidade de disco (disquetes de $5 \frac{1}{4}$ ou $3 \frac{1}{2} 2$ polegadas) ligada fisicamente a um computador; unidade de disco local. unidade de disco que está sendo usada ou foi 
selecionada. unidade de disco de um computador da rede, mas que pode ser usado por todos os outros." Mesmo sendo um significado relacionado à informática, este não é o sentido usado na frase, que não se refere a disco, mas a um programa que torna possível a comunicação entre hardwares ou softwares de um computador. (novamente, usam-se anglicismos para explicar outros anglicismos).

3) desde ahi debes bajar el chipset y el audio. desde la pagina de Nvidia.

CHIPSET - não foi encontrada tradução para o termo.

4) Lo unico que no pude encontrar fue el driver del modem interno.

MODEM - na verdade a palavra formou-se a partir de duas outras palavras: modulador e demodulador, mas já é possível encontrá-la no dicionário como se fosse um verbete. Significa dispositivo conector entre um equipamento e uma linha de comunicação, cuja função é converter os dados a uma forma compatível com a linha de comunicação e vice-versa, a fim de que esses dados se tornem disponíveis para a transmissão e processamento.

O dicionário de inglês traz como tradução: aparelho que converte informação digital em informação analógica, que pode ser transmitida por linhas telefônicas.

Reportagem: Unidos para voar

1) En acuerdo con la programación, en el show de Nueva York atuan estrelas...

SHOW - palavra já estudada.

Reportagem: Músicos no Rock In Rio Lisboa 2008

1) ... a intepretar rock, soul y blues. 
ROCK - a música contribui com grande parte dos anglicismos pelo mundo. Esta palavra já foi estudada, assim como as outras abaixo.

SOUL - idem.

BLUES - idem.

2) ... el principe de hip hop.

HIP HOP - mais uma contribuição de anglicismo importada através da música.

Reportagem: Un nuevo virus se extiende a través de Facebook

1) aconsejan a los usuarios que hayan recibido correo no deseado o spam que utilicen uno de los antivirus gratuitos en línea, de una lista publicada en la misma página, y que cambien las contraseñas de sus cuentas.

SPAM - não foi encontrada em nenhum dos dicionários.

A enciclopédia explica como abreviação em inglês de "spiced ham" (presunto condimentado), é uma mensagem eletrônica não-solicitada enviada em massa.

Na sua forma mais popular, um spam consiste numa mensagem de correio eletrônico com fins publicitários. O termo spam, no entanto, pode ser aplicado a mensagens enviadas por outros meios e noutras situações até modestas.

ANTIVIRUS - não foi encontrada nos dicionários, mas refere-se a um programa de computador instalado com a função de bloquear "vírus", ou seja, programas maliciosos que se instalam com o intuito de prejudicar alguém, roubar informações ou espionar.

2) ... les recomienda ver un vídeo colocado en otra página web. 
WEB - novamente aparece.

3) ya afectó a otra red social en internet.

INTERNET - outra palavra sempre presente nas pesquisas e já estudada.

\subsubsection{CLARÍN}

Reportagem: Moodle llena la geografía educativa española de campus virtuales

1) Muy pocos proyectos de software libre han conseguido lo que la plataforma virtual de aprendizaje Moodle: desbancar a sus adversarios en seis años.

SOFTWARE - não apresenta tradução, mas refere-se a programas de computador.

2) A eso se dedican los llamados partners.

PARTNERS - o dicionário de inglês apresenta a palavra "socio" como tradução.o dicionário de espanhol não traz a palavra.

Reportagem: Dougiamas, creador de Moodle: "Internet cambia cómo se educa" 1) Impartí algunos cursos de un master usando Moodle y así tenía feedback de los estudiantes sobre qué cosas añadir, qué cambiar.

MASTER - a tradução do inglês para o espanhol é "maestro".

FEEDBACK - o dicionário de inglês apresenta a palavra "reacción". 


\section{ARTE}

Reportagem: Ante la catástrofe, simulación

1) ... a través de una acción colaborativa online.

ONLINE - é o oposto de offline. Significa "na linha".

\section{TECNOLOGÍA}

Reportagem: Compra segura por Internet

1) Cada día, los timos, las estafas y los ataques fraudulentos (phishing) son más habituales.

INTERNET - mais uma vez aparece a internet.

PHISHING - não foi encontrada tradução ou significado nos dicionários. Refere-se a uma mensagem eletrônica com conteúdo malicioso. É um spam destrutivo.

2) En el caso de Macintosh, pinche en la manzana de Apple y haga clic en la opción Actualización de software.

CLIC - deriva-se da palavra "click", já estudada.

SOFTWARE - já estudada.

Reportagem: Tecnología para 'pymes'

1) ...el déficit eterno del principal tejido productivo español, según la mayoría de los expertos.

DÉFICIT - já estudada.

PYMES - esta palavra não foi encontrada em nenhum dos dicionários pesquisados EXPERTOS - palavra já estudada. 
Reportagem: La revolución Twitter y los medios

TWITTER - o dicionário de inglês traz como tradução 1 gorjeio, trinado, chilro. 2 riso silencioso. 3 excitação, tremor.

Reportagem: Los mundos virtuales se abren paso en la colaboración empresarial 1) ... programadores y expertos en usabilidad trabajan en proyectos como fusionar chats y mundos virtuales.

CHAT - não é mostrada tradução para o espanhol (ou o português). O siginificado da palavra é palestra, tagarelice, bate-papo. conversar, tagarelar, prosear.

2) Es una preocupación enorme, por eso los grids propios construidos en código abierto son la solución.

GRID - curiosamente, o dicionário de inglês-espanhol traz como tradução a palavra "red".

O significado de grid pode ser apontado como 1. grade. 2 grelha. 3 placa de acumulador.

Reportagem: Nace .tel, directorio multiplataforma que almacena los datos en la DNS 1) El número de teléfono fijo, el móvil y el fax.

FAX - não existe tradução para a palavra.

2) La página, el blog...

BLOG - palavra já estudada. 
3) ... una persona o empresa sin necesidad de crear una web ni tenerla alojada en un servicio de hosting.

WEB - mais uma vez aparece este verbete.

HOSTING - a palavra é traduzida para o espanhol como "hospedando".

4) ... sino que devolverá la información de contacto directamente al terminal, permitiendo además la comunicación instantánea con un simple clic.

CLIC - palavra já estudada, deriva-se de click.

Reportagem: El correo es más efectivo que el SMS

1) Se puede comprar un pen drive de 64 gigas por menos de 200 euros.

PEN DRIVE - palavra já estudada.

2) En 1992, un disco de un computador de 1 gigabyte costaba más de un millón de pesetas.

GIGABYTE - não mostra tradução. É uma unidade de medida de informação que equivale a 1000000000 bytes. Cada byte é o espaço necessário para armazenar um caracter. (novamente usa-se anglicismos na explicação)

\subsection{ANÁLISE DOS JORNAIS ON LINE}

Segue-se agora a análise dos verbetes encontrados nas versões online. 
TABELA - Palavras pesquisadas nos jornais escolhidos (versões on line)

\begin{tabular}{|c|c|c|c|c|}
\hline & PALAVRAS PESQUISADAS & $\begin{array}{l}\text { FOLHA ON } \\
\text { LINE }\end{array}$ & CLARÍN & EMOL \\
\hline 1 & Affair & $\bar{X}$ & & \\
\hline 2 & Antivirus & & & $\mathbf{X}$ \\
\hline 3 & Bar & $\mathbf{X}$ & & \\
\hline 4 & BBB Big Brother Brasil & $\mathbf{X}$ & & \\
\hline 5 & Blog & $\mathbf{X}$ & $\mathbf{X}$ & \\
\hline 6 & Bloqueia & $\mathbf{X}$ & & \\
\hline 7 & Bloqueou & $\mathbf{x}$ & & \\
\hline 8 & Blues & & & $\mathbf{X}$ \\
\hline 9 & Boxe & $\mathbf{x}$ & & \\
\hline 10 & Chat & & $\mathbf{X}$ & \\
\hline 11 & Chipset & & & $\mathbf{X}$ \\
\hline 12 & Clic & & $\mathbf{X}$ & \\
\hline 13 & Commodities & $\mathbf{X}$ & & \\
\hline 14 & Déficit & $\mathbf{x}$ & $\mathbf{X}$ & \\
\hline 15 & Design & $\mathbf{X}$ & & \\
\hline 16 & Drives & & & $\mathbf{X}$ \\
\hline 17 & DVD & $\mathbf{X}$ & & \\
\hline 18 & E-Mail & $\mathbf{X}$ & & \\
\hline 19 & Expertos & & $\mathbf{X}$ & $\mathbf{X}$ \\
\hline 20 & Fax & & $\mathbf{X}$ & \\
\hline 21 & Feedback & & $\mathbf{x}$ & \\
\hline 22 & Flash & $\mathbf{X}$ & & \\
\hline 23 & Gigabyte & & $\mathbf{X}$ & \\
\hline 24 & Grid & & $\mathbf{X}$ & \\
\hline 25 & Hip Hop & & & $\mathbf{X}$ \\
\hline 26 & Hosting & & $\mathbf{X}$ & \\
\hline 27 & Impeachment & $\mathbf{X}$ & & \\
\hline 28 & Internet & $\mathbf{X}$ & $\mathbf{X}$ & $\mathbf{X}$ \\
\hline 29 & Join Venture & & & $\mathbf{X}$ \\
\hline 30 & Link & $\mathbf{X}$ & & \\
\hline 31 & Marqueteiros & $\mathbf{X}$ & & \\
\hline 32 & Marketing & $\mathbf{x}$ & & \\
\hline 33 & Master & & $\mathbf{X}$ & \\
\hline 34 & Miss & $\mathbf{X}$ & & \\
\hline 35 & Modem & & & $\mathbf{X}$ \\
\hline 36 & Offline & $\mathbf{X}$ & & \\
\hline 37 & OK & $\mathbf{x}$ & & \\
\hline 38 & Online & & $\mathbf{X}$ & \\
\hline 39 & Partners & & $\mathbf{x}$ & \\
\hline 40 & Passaporte & $\mathbf{X}$ & & \\
\hline 41 & Pen Drive & & $\mathbf{x}$ & \\
\hline 42 & Performance & $\mathbf{X}$ & & \\
\hline 43 & Phishing & & $\mathbf{X}$ & \\
\hline 44 & Pymes & & $\ddot{X}$ & \\
\hline 45 & Ranking & $\mathbf{x}$ & & \\
\hline 46 & Reality Show & $\mathbf{X}$ & & \\
\hline 47 & Recordes & $\mathbf{x}$ & & \\
\hline 48 & Rock & & & $\mathbf{X}$ \\
\hline 49 & Search Marketing & $\mathbf{X}$ & & \\
\hline 50 & Shopping & $\mathbf{x}$ & & \\
\hline 51 & Show & $\mathbf{X}$ & & $\mathbf{X}$ \\
\hline 52 & Site & $\mathbf{x}$ & & \\
\hline 53 & Sky & $\mathbf{X}$ & & \\
\hline 54 & Slogan & $\mathbf{X}$ & & \\
\hline
\end{tabular}




\begin{tabular}{|c|c|c|c|c|}
\hline 55 & Software & & $X$ & \\
\hline 56 & Soul & & & $\mathbf{X}$ \\
\hline 57 & Spam & & & $\mathbf{X}$ \\
\hline 58 & Superávit & $\mathbf{X}$ & & \\
\hline 59 & Test-Drive & $x$ & & \\
\hline 60 & Topless & $\mathbf{X}$ & & \\
\hline 61 & Tracking & $x$ & & \\
\hline 62 & Triple Play & $x$ & & \\
\hline 63 & Twitter & & 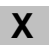 & \\
\hline \multirow[t]{2}{*}{64} & Web & $\mathbf{X}$ & $\mathbf{X}$ & $\mathbf{X}$ \\
\hline & TOTAL & 38 & 20 & 14 \\
\hline
\end{tabular}

A tabela acima mostra que, das 64 palavras encontradas nos jornais, 38 apareciam no jornal em língua portuguesa, representando mais que os dois outros jornais juntos. Nesta situação ficou evidenciado que o Brasil é campeão de anglicismos, quando comparado aos vizinhos Chile e Argentina.

Foram encontradas, somando-se as versões online e escrita, 223 anglicismos em todos os jornais pesquisados. A tabela abaixo mostra quantos e quais deles tinham tradução em seu idioma e quantos e quais trazem exclusivamente a palavra em inglês como significado.

PALAVRAS QUE TINHAM EQUIVALENTE NO IDIOMA

\begin{tabular}{ll}
\hline Advertainment & Antivirus \\
\hline Affair & Bar \\
\hline After office & BBB Big Brother Brasil \\
\hline All inclusive & Blog \\
American way of life & Bloqueia \\
Baby & Bloqueou \\
Bodies, the exhibition & Blues \\
Boom & Boxe \\
Cartum & Business intelligence \\
Chat & Business risk management \\
Chef & Cds \\
Chessies & Charge \\
Courier & Chipset \\
Cover & Clic \\
Deficit & Clown \\
\hline
\end{tabular}

PALAVRAS SEM EQUIVALENTE NO IDIOMA 


\begin{tabular}{|c|c|}
\hline Expertos & Club \\
\hline Face to face & Commodities \\
\hline Feedback & Cool \\
\hline Feeling & Copyright \\
\hline Fiction & Cosplay \\
\hline Flyers & Country \\
\hline Gay & Crack \\
\hline Hobby & Data mining \\
\hline Hosting & Design \\
\hline Impeachment & Diésel \\
\hline Kit & Disc jockers \\
\hline Managers & Doping \\
\hline Master & Drives \\
\hline Mistery shoppers & DVD \\
\hline Music & E-mail \\
\hline Nine, eight, seven, six .. Zero & Extra \\
\hline Off & Fallow up \\
\hline Offline & Fast-food \\
\hline OK & Fax \\
\hline One, two, three, four & Flash \\
\hline Online & Folk \\
\hline Partners & Fowards \\
\hline Personal & Fútbol \\
\hline Planet básquet & Gigabyte \\
\hline Pocket show & GPS \\
\hline Premium & Grand prix \\
\hline Ranking & Grid \\
\hline Search Marketing & Hackers \\
\hline Self-service & Happy hour \\
\hline Sensation white & Hip hop \\
\hline Sex symbol & Hip hoperos \\
\hline Shop & Hiper \\
\hline Sky & Hóckey \\
\hline Slogan & Homeless \\
\hline Software & Hotel \\
\hline Standard & Hotspots \\
\hline Start up & Internet \\
\hline Style & Jazz \\
\hline Test & Jet ski \\
\hline Test-Drive & Join Venture \\
\hline Thriller & Know how \\
\hline Top & Leasing \\
\hline Touch & Link \\
\hline Triple Play & Lobbista \\
\hline Twitter & Lobby \\
\hline Underground & Lounge bar \\
\hline \multirow[t]{3}{*}{ VIPs } & Main street \\
\hline & Marketing \\
\hline & Marqueteiros \\
\hline
\end{tabular}




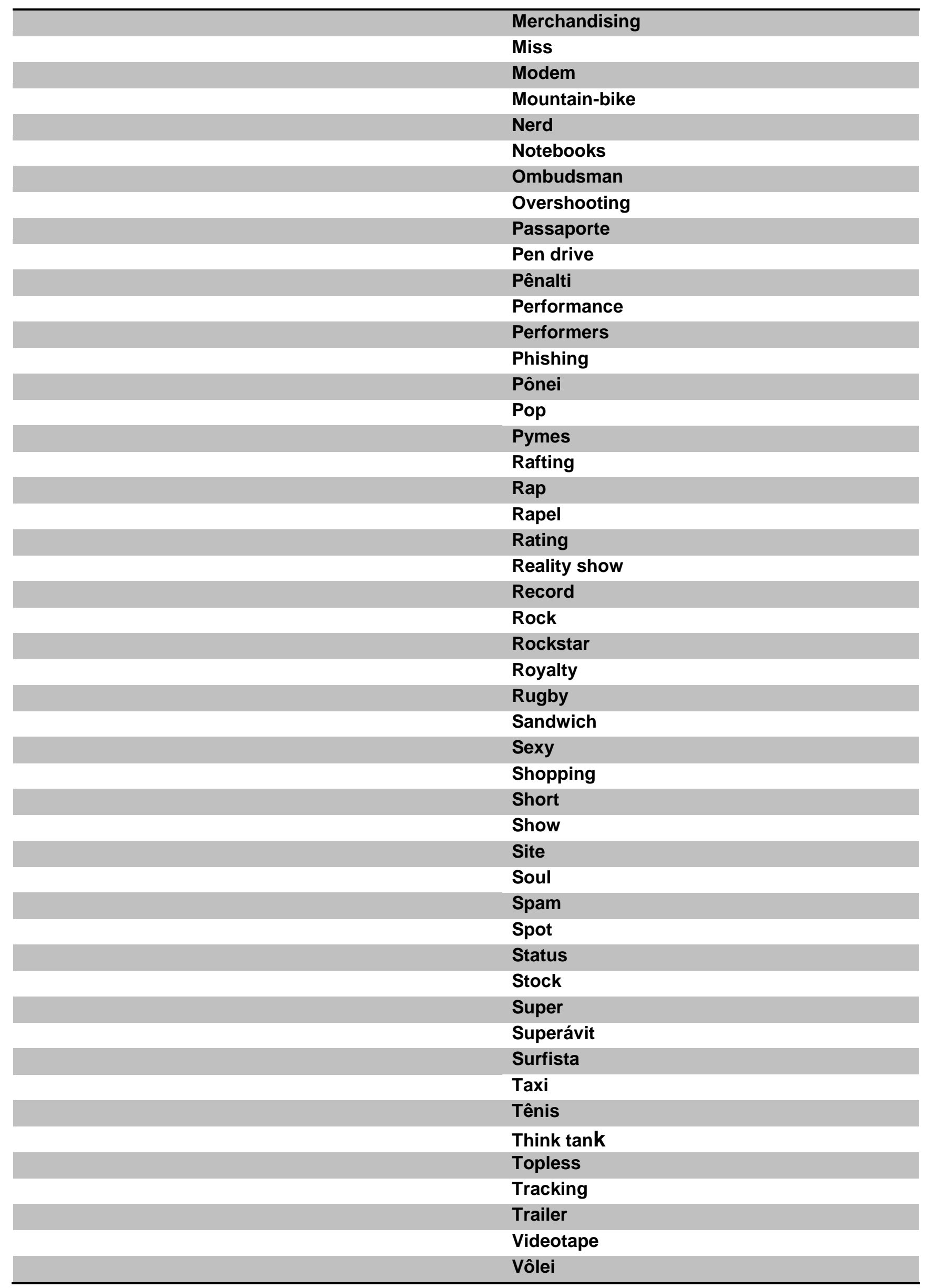


A tabela acima mostra que, das palavras pesquisadas, apenas 62 tinham equivalente na língua receptora, enquanto 116 não tinham. Isso pode ser interpretado como uma aceitação de anglicismos pela língua receptora. Quando surgem objetos, situações ou costumes trazidos de outros lugares com seus nomes próprios, estes nomes passam a ser aceitos e utilizados, sem ser reconhecida a necessidade de encontrar-se explicação e tradução na língua receptora, passandose a adotar a palavra original.

Para Paiva (1991, p. 125), "as causas do empréstimo lexical são a necessidade de nomear novos objetos, conceitos e lugares, a convivência entre falantes de idiomas diferentes e o imperialismo cultural". Já Kelm (2001, p. 12) aponta como causas da entrada de tantos estrangeirismos em outras línguas a moda (status), a ausência de algo que não existe na cultura local e, por fim, o que ele denomina de "natureza inovadora da fala", que faz com que nos esforcemos para melhor representar o que sentimos. Steinberg (2003, p. 11) diz que "a necessidade de nomear novos conceitos, novos objetos, novas invenções, novas situações, que venham a fazer parte (de uma) comunidade lingüística, dá origem aos neologismos". Além disso, ela aponta como demais causas: mudanças sócio-econômicas, migrações e momentos históricos (STEIBERG, 2003, p. 13).

Mesmo assim, ainda foram encontradas mais de 60 palavras que foram utilizadas por vontade espontânea, apesar de terem equivalência no idioma. Esse processo de aceitação acontece, na maioria das vezes, por motivações ou condições extralingüísticas: o poder político, a supremacia econômica e tecnológica 
e a influência cultural. A hegemonia dos Estados Unidos e a amplitude de sua presença em escala jamais conhecida na história, explicam com facilidade a força e a predominância do inglês na América Latina. Como ponderou Vendryès, os empréstimos "de forma alguma pressupõe que se fale, ou mesmo saiba a língua cuja palavra se adota" (VENDRYES, 1923, p. 341), o que propicia seu emprego é o modismo, a afetação ou o esnobismo - com a preocupação de ser "moderno" ou culto, de exibir sofisticação -, o charme que muitos vêem no uso de um estrangeirismo. 


\section{CONSIDERAÇÕES FINAIS}

O contato e a aprendizagem de uma outra língua faz parte de uma relação intercultural visando à promoção do entendimento entre as pessoas. Com a globalização, o mundo se transforma em uma aldeia global, onde se vive além de seu país e, o inglês, atualmente, tem esse papel fundamental de permitir a comunicação entre povos de raças e línguas diferentes.

Atitudes que não levem em conta as tendências deste milênio, como leis proibindo o uso de palavras de origem inglesa, não serão eficazes. Ao contrário, temos que reconhecer que as línguas modernas não permanecem estáticas e fechadas, mas se atualizam continuamente. Incorporar termos estrangeiros faz parte desse processo de evolução natural mediante o qual as línguas se adequam às necessidades e mudanças do momento.

Como apontou Coseriu (1978), a língua nunca está pronta. Ela é sempre algo por refazer. A cada geração, ou mesmo em cada situação de fala, cada falante recria a língua. Dessa forma, ela está sujeita a alterações nessa recriação. Por outro lado, depende de uma tradição, já que cada falante diz as coisas de determinada maneira em grande parte porque é daquela maneira que se costuma dizer. Há então um delicado jogo de continuidade e de inovações.

É importante termos em mente que as línguas são heterogêneas, afastandoas da idéia de sistemas prontos, perfeitos, acabados. Pode haver nelas heterogeneidade de origem externa ou interna à língua, e a heterogeneidade de um tipo pode gerar também heterogeneidade de outro tipo. Sendo assim, a língua está a todo momento se equilibrando entre tendências potencialmente conflitantes, e até 
mesmo opostas, sujeitando-se a sofrer mudanças, pois esse equilíbrio pode vir a ser alterado por qualquer tipo de fator, interno ou externo.

Não se pode, porém, permitir uma invasão acrítica, sem levar em conta a integridade da língua portuguesa. Na verdade, abusar do estrangeirismo sem necessidade real, por considerar que com isso se está sendo chique ou demonstrando saber, acaba, ao contrário, sendo um sinal de ignorância e desprezo pelas origens. Quando existirem, no português, termos equivalentes que atendem a realidade empírica, devemos usá-los sem medo de perda de status, eficiência ou charme.

Sempre que uma língua influencia outra, os discursos nacionalistas surgem tentando prever uma situação apocalíptica gerada por tais empréstimos. Nestes discursos não é verificado que as línguas mudam. Dessa forma, os estrangeirismos não representam o fim de uma língua, tampouco a desnacionalização ou o empobrecimento da língua que recebe o empréstimo. 0 processo é justamente o contrário, tal invasão de estrangeirismo, no caso das línguas portuguesa e espanhola, não empobrece, mas enriquece ao incorporar termos que não são previstos em seus léxicos. Os excessos, como leitos dos rios depois das cheias, voltam ao leito anterior, com um ou outro elemento a recordar as tormentas vencidas.

Em pleno século XXI, vivendo sob os efeitos da globalização, o mais importante é a conscientização crítica, capaz de discernir entre o que é o verdadeiro intercâmbio cultural e lingüístico e o que é mero modismo. Não há línguas estáticas, ou mesmo imutáveis; se assim fosse, ainda estaríamos falando latim. Acreditar que no Brasil todos falam e se compreendem mutuamente em todos os lugares do país seria, no mínimo, uma utopia ou ignorância pura dos aspectos lingüísticos das 
variações regionais. As línguas mudam "nem para o bem nem para o mal", mas sim para atender às necessidades dos usuários da língua.

Há uma preocupação inicial de conceituar o termo estrangeirismo, bem como o relacionando aos conflitos dentro da comunidade que faz o empréstimo, por ocorrerem choques da associação de estrangeirismos versus valores culturais. Mas, a maioria dos lingüistas afirma que os conflitos causados por questões lingüísticas, envolvendo estrangeirismos, são discursos superficiais e equivocados sobre a natureza da linguagem.

Apesar de muitos deplorarem essa situação de invasão lingüística e lutarem para a língua materna permanecer intacta, outros são mais realistas ou conscientes das forças de mudanças que estão embutidas nas megatendências apresentadas acima. Em relação direta com esse assunto, o lingüista americano Fischer, em entrevista à revista Veja, afirmou que daqui a 300 anos não haverá mais o português e sim o "portunhol" (mistura da língua portuguesa com a espanhola). Valorizando a transformação das línguas, o especialista diz que isto acontecerá porque o Brasil está cercado de países que falam o espanhol e, conseqüentemente, os países latino-americanos deverão intercambiar todo tipo de informação e desenvolver uma língua original.

Segundo Fischer, esse processo vai acontecer em todo o mundo, diminuindo o número de idiomas de 6.000 para aproximadamente 1.000, em apenas 100 anos.

A percepção da necessidade de uma multiplicidade lingüística nasce do conceito de que não existe língua pequena nem melhor, apenas diferente, com todas as complexidades e características próprias que os seus falantes imprimam desde o surgimento de cada uma delas até a sua atual estruturação. 
Assim, constatamos que os anglicismos não alteram o fundo léxico comum e, igualmente, não modificam a sintaxe das línguas portuguesa e espanhola. Quando se mantêm sólidos o fundo léxico comum e a gramática com seus elementos de fonética, morfologia e sintaxe, não se pode falar em descaracterização ou enfraquecimento dos idiomas receptores de anglicismos.

O léxico tem a capacidade de mostrar o grau de desenvolvimento atingido por uma sociedade como reflexo de sua vida sócio-econômico-cultural. O fundo comum do léxico é resistente nas mesmas proporções que a gramática, uma vez que é constituído para expressar os fatos da vida cotidiana de modo geral e coloquial. Portanto, ele recebe estrangeirismos para dar conta das coisas do convívio social e da vida.

Como a língua está sempre sendo recriada, ela comporta o surgimento de inovações a todo momento. O crucial é que nem toda inovação vinga ou é realmente incorporada e difundida pelos falantes de uma determinada comunidade. Com isso, verificamos que a permanência de um empréstimo no vernáculo se dá pelos falantes da língua, pois o funcionamento de uma língua não pode ser entendido no vácuo. A língua necessariamente faz parte de uma sociedade que a utiliza, a influencia e é influenciada por ela. 


\section{REFERÊNCIAS BIBLIOGRÁFICAS}

ACOSTA, L. A. Transferencias lingüísticas: préstamos y calcos. Problemas de la traducción. Madrid: Fundación "Alfonso X el Sabio", 1987.

AGOST, R. El paper de la traducció audiovisual en la conformació de l'estàndard oral català. Estudios de lingüística aplicada. Eds. J. L. Otal et al. Castellón: Universitat. 817-824, 1997.

AGOST, R. Traducción y doblaje: palabras, voces e imágenes. Barcelona, Ariel, 1999.

ALVES, F. Dicionário de expressões estrangeiras correntes na língua portuguesa. 2.ed. São Paulo: Atlas, 2000.

ALVES, I. M. Neologismo: criação lexical. São Paulo: Ática, 1990.

ASSOCIAÇÃO BRASILEIRA DE NORMAS TÉCNICAS. NBR 6023: informação e documentação - apresentação de citações em documentos. Rio de Janeiro, ago 2001.

BAGNO, M. Dramática da língua portuguesa: tradição gramatical, mídia \& exclusão social. 2. ed. São Paulo, 2001.

BAGNO, M. Preconceito lingüístico - o que é, como se faz. 38. ed. São Paulo: Loyola, 2005.

BARBOSA, R.H.S. AIDS, Gênero e Maternidade. Projeto de Tese de Doutorado, ENSP/FIOCRUZ: Rio de Janeiro, 1999.

BLUM-KULKA S, HOUSE J AND CASPER G. C. Cultural Pragmatics: Requests and Apologies. Norwood,. NJ: Ablex, 1989.

BOGDAN, R.; BIKLEN, S. Investigação Qualitativa em Educação: uma introdução à teoria e aos métodos. Porto: Porto Editora, 1999.

BROWN R.; LEWINSON, M. Words and Things. An Introduction to Language. Nova York, The Free Press, 1968.

CANALE, M. "From communicative competence to communicative language pedagogy". Language and Communication. Eds J.Richard y R.Smith. London: Longman. 2-27, 1983.

CANALE, M. Y M.SWAIN. "Theoretical bases of communicative approaches to second language teaching and testing". Journal of Applied Linguistics 1/1: 1-47, 1980. 
CARBONELL, O. C. "Del «conocimiento del mundo» al discurso ideológico: el papel del traductor como mediador entre culturas". El papel del traductor. Eds. E.Morillas y J.P.Arias. Salamanca: Ediciones Colegio de España, 1997.

CARVALHO, N. Empréstimos Lingüísticos. São Paulo: Ática, 1989.

CLYNE, M. Intercultural Communication Breakdown and Communication Conflict: Towards a Linguistic Model and its Exemplification. Deutsch im Kontakt mit anderen Sprachen/German in Contact with Other Languages. Eds. C.Molony, H.Zobl y W.Stölting. Kronberg: Scriptor-Verlag. 129-146, 1977.

CLYNE, M. Perspectives on Language Contact. Melbourne: Hawthorn Press, 1972.

COHEN, L.; MANION, L. Métodos de investigación educativa. Madrid, Etorial La Muralia, 1990.

COSERIU, E. Alcance y límites de la gramática contrastiva. Gramática, semántica, universales. Madrid: Gredos, 1970 e 1978.

DARBELNET, J. Le français en contact avec I'anglais en Amérique du Nord. Québec: Presses de l'Université Laval, 1976

DESHAIES, B. Metodologia da Investigação em Ciências Humanas. Lisboa: Instituto Piaget, 1997.

FARACO, C. A.; TEZZA C. Prática de texto para estudantes universitários. 10. ed. Petropólis: Vozes, 2002.

FERREIRA, A. B. de H. Novo dicionário da língua portuguesa. 1. ed. Rio de Janeiro: Nova Fronteira, 1975.

GRIJELMO, Alex "Contra la palabra tregua". Diario EL País, 2 de junio de 1999.

HAUGEN, E. The Analysis of Linguistic Borrowing, Language 26: 210-231, 2000.

HERDER, B. El anglicismo en el español actual, Madrid: Arco Libros, 1987.

HERRERA SOLER, H. Un análisis sobre la evolución de los préstamos que provienen del inglés económico. Diálogos Hispánicos, 15, 97-110, 1990.

INIGO, M. Y WESTALL, D. The Translation of Realia in «A Perfect World 》. Actes del III Congrés Internacional sobre Traducció. Barcelona: Universitat Autònoma, 1998.

INTERNATIONAL COMMITTEE OF MEDICAL JOURNAL EDITORS. (Vancouver Style) - Grupo de Vancouver

INTERNATIONAL STANDARIZATION ORGANIZATION (ISO) - ISO 690 e 690.2 
JIMÉNEZ, O. "El peso de la ausencia: el papel del traductor en la adaptación al español de los títulos de largometrajes en inglés". El papel del traductor. Eds. E.Morillas y J.P.Arias. Salamanca: Ediciones Colegio de España. 293-317, 1997.

LABOV, W. Modelos Sociolingüísticos. Madrid: Cátedra, 1982.

LABOV, W. Sociolinguistic Patterns. Philadelphia: University of Pennsylvania Press, 1972.

LAGUEUX, P-A. La part des emprunts à l'anglais dans la création néologique, en France et au Québec, Le français en contact avec l'anglais. En hommage à Jean Darbelnet. Ed. M.Pergnier. París: Didier Erudition, 1988.

LLOSA, M. V. A globalização vista por um Prêmio Nobel, O Estado de São Paulo. São Paulo, 26/05/2002.

LÓPEZ, M, H. Dialectología y sociolingüística: temas puertorriqueños, Madrid: Playor. 86-99, 1994.

LORENZO, E. Anglicismos hispánicos, Madrid: Fundación Juan sep, 1987.

LORENZO, E. Anglicismos. La lengua española, hoy. Comps. M.Seco y G.Salvador. Madrid: Fundación Juan March, 1995.

LORENZO, E. El español de hoy, lengua en ebullición, 3aed., Madrid: Gredos, 1980.

LUCCHESI, D. A Variação na Concordância de Gênero em uma Comunidade de Fala Afro-brasileira: Novos Elementos sobre a Formação do Português Popular do Brasil. Rio de Janeiro: UFRJ. Tese de doutorado, 2000.

LÜDKE, M., ANDRÉ, M. E. D. A. Pesquisa em educação: abordagens qualitativas. São Paulo: EPU, 1986.

LYONS, J. Semántica. Barcelona: Teide, 1981.

MEDINA, M. J. R. La presencia del inglês em España. Universidad de Las Palmas de Gran Canaria, 2007.

MICHAELIS. Dicionário Inglês/Espanhol. São Paulo: Melhoramentos, 2005.

MICHAELIS. Dicionário Inglês/Português. São Paulo: Melhoramentos, 2008.

MICHAELIS. Dicionário Português. São Paulo: Melhoramentos, 2007.

MINAYO, C. S. O Desafio do Conhecimento - Pesquisa Qualitativa em Saúde, Hucitec-Abrasco: São Paulo, 1994.

MONTEIRO, J. L. Para compreender Labov. Petrópolis-RJ: Vozes, 2000. 
MONTES GIRALDO, J. J. Calcos recientes del inglés en español. Thesaurus 40: 17-50, 1985.

MOUNIN, G. Linguistique et traduction. Bruselas: Dessart et Mardaga, 1976.

NAVARRO, F. A. Problemas de género gramatical, vol. 110(2), pp. 68-75, 1998.

NIDA, E A. Toward a Science of Translating: With Special Reference to Principles and Procedures Involved in Bible Translating. Leiden: Brill, 1964.

NUNES DE LEÃO, D. Origem da Língua Portuguesa. Lisboa: Pro Domo, 2001.

PAYRATÓ, L. 1992. Pragmática y lenguaje cotidiano. Apuntes sobre el catalán coloquial. Revista de Filología Románica 9: 134-153, 1992.

PERGNIER, M. Les anglicismes. Danger ou enrichissement pour la langue. París: P.U.F, 1989.

PERINI, M. A. A língua do Brasil amanhã e outros mistérios. 2. ed. São Paulo: Parábola, 2006.

PRATT, C. El anglicismo en el español peninsular contemporáneo, Madrid: Gredos, 1980.

RIBEIRO, H. M. P.; KLEIN, M. V. M. A Língua em Constante Evolução. CuritibaPR: Editora da UFPR, 2007.

RICHARDSON, R. J. et al. Pesquisa social: métodos e técnicas. São Paulo: Atlas, 1985.

RIQUELME, J. Los anglicismos. Anglicismos y angliismos: huéspedes de la lengua. Alicante: Aguaclara, 1998.

SAINT-GEORGES, P. Práticas e métodos de investigação em ciências sociais. Lisboa: Gradiva, 1997.

SALGADO, E. O fim do português- entrevista com Steven Roger Fischer. Veja, 05/04/2000.

SANTOYO, J. C. El delito de traducir. León: Universidad, 1996.

SMITH, C. et al. Diccionario Collins Español-Inglés, English-Spanish. Barcelona: Collins/Grijalbo, 1993.

STEINER, P. The sociology of economic knowledge. European Journal of Social Theory, 4 (4): 443-458, 2001.

STONE, H. Los anglicismos en España y su papel en la lengua oral, en RFE,. XLI, 1957. 
THOMAS, J. Cross-cultural Pragmatic Failure. Applied Linguistics. 4.2: 91-112, 1983.

VALERO, C. et al. Polisistemas en contacto: ciertos condicionantes que afectan al transvase de información. Estudios de lingüística aplicada. Eds. J.L.Otal et al. Castellón: Universitat. 843-850, 1997.

VÁZQUEZ AYORA, G. Introducción a la traductología. Washington: Georgetown University Press, 1977.

VENDRYÈS, J. Le Langage - Introduction linguistique à l'histoire. Paris: Albin Michel, 1923

WEINREICH, U. Languages in Contact: Findings and Problems. La Haya: Mouton, 1953 e 1968.

WIERZBICKA, A. Cross-cultural Pragmatics. The Semantics of Human Interaction. Berlín/Nueva York: Mouton de Gruyter, 1991.

http://en.wikipedia.org/wiki/El_Mercurio

http://ipv.pt/anglicismos/

http://ipv.pt/econogloss/

http://pt.wikipedia.org/wiki/Hip-hop

http://pt.wikipedia.org/wiki/Jet_ski

http://pt.wikipedia.org/wiki/Mountain_bike

http://pt.wikipedia.org/wiki/Nerd

http://pt.wikipedia.org/wiki/Rapel

http://translate.eu/es/translators/English-Spanish 